
Closing the divide in Malawi

How to reduce inequality and

increase prosperity for all

\section{Table of contents}

Endorsements

Page 4

Executive Summary

Page 5

How to reduce inequality and increase prosperity for all

Page 20

Malawi's inequality crisis in context

Page 22

Tackling the drivers on inequality

Page 26

Make the economy work for everyone

Page 35

Fiscal justice: the fair approach to reducing inequality

Page 44

Conclusion

Page 61

Notes

Page 62

Acknowledgements

Page 66 
Closing the divide in Malawi

How to reduce inequality and

increase prosperity for all

\section{ENDORSEMENTS}

Mr. Dalitso Kubalasa, Executive Director, Malawi Economic Justice Network (MEJN)

"Closing the divide in Malawi is about doing things differently by fully operationalizing policy recommendations to address the huge differences in the quality of life and standards of living, that separate the minority rich from the poor masses because of extreme inequality. The study is an in-depth analysis of the critical aspects of governance and socio-economic factors that are making it difficult for ordinary citizens to fruitfully take advantage of the available economic opportunities largely due to the way the political and economic power is exercised and monopolized by a narrow elite. From the different sectors, the study brings to the fore, the inherent dimensions of inequality, its causes and its consequences, as well as unpack the public policies and processes that are a part of the problem and ones that can be part of the solution. Most importantly, the study's succinct insights stand out. I recommend this study to policy makers, development specialists, the donors and all those concerned about the yawning social, economic and political gaps in the modern Malawi society, all in the quest for progressively doing things differently."

\section{Hon Grain Malunga, Coordinator, Chamber of Mines; Former Minister of Energy}

"Important and insightful paper......this is an important analysis and policy proposal not to be missed by government, donors, private sector and non-governmental organizations working to end poverty and inequality."

Hon Agnes M. Nyalonje, Vice Chairperson, Public Accounts Committee of Parliament, and Member of the Parliamentary Committee on Education, Science and technology "This report is a welcome contribution to the inequality debate started by Oxfam's 2015 report. With $70 \%$ of Malawians living below the international poverty line of $\$ 1.90$ per day, with hoe-based rural agriculture having to compete globally with mechanized agriculture, and with poorly equipped schools and universities having to prepare students to compete in a knowledge-based global economy, the challenges facing Malawi are many. I would encourage the newly created National Planning Commission to focus on inequality reduction as a key indicator for future planning and for the Commission to review and generate evidence that can integrate inequality reduction within a strategic plan for national development."

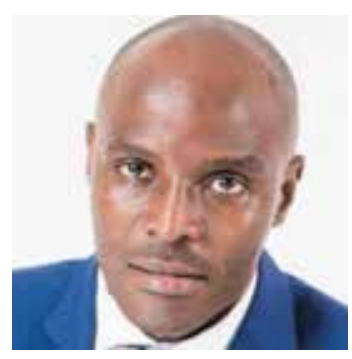

MR. DALITSO KUBALASA EXECUTIVE DIRECTOR, MALAWI ECONOMIC JUSTICE NETWORK (MEJN)

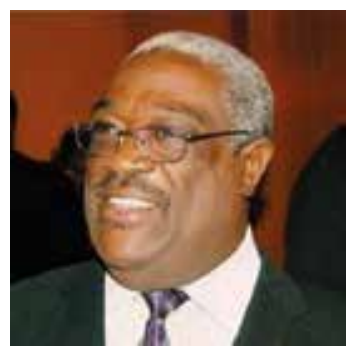

HON GRAIN MALUNGA, COORDINATOR, CHAMBER OF MINES; FORMER MINISTER OF ENERGY

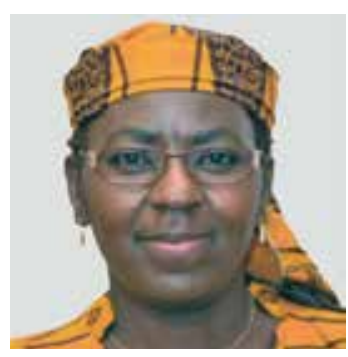

HON AGNES M. NYALONJE, VICE CHAIRPERSON, PUBLIC ACCOUNTS COMMITTEE OF PARLIAMENT, AND MEMBER OF THE PARLIAMENTARY COMMITTEE ON EDUCATION, SCIENCE AND TECHNOLOGY 
Closing the divide in Malawi

How to reduce inequality and

increase prosperity for all

\section{EXECUTIVE SUMMARY}

Malawi is one of the poorest countries in the world, ${ }^{1}$ with $70 \%$ of the population living on less than $\$ 1.90$ a day. ${ }^{2} \mathrm{~A}$ low level of economic development - alongside seemingly regular shocks - has left the nation's finances perpetually constrained. The country is stuck in a deadlock of slow growth which is unequally distributed, where poverty and inequality are two faces of the same coin. Economic inequality is growing significantly: in just seven years between 2004 and 2011, the gap between the richest 10\% of Malawians and the poorest $40 \%$ increased by almost a third. ${ }^{3}$ If inequality continues to rise as it has in recent years, by 20201.5 million more Malawians will be poor. ${ }^{4}$ Even rapid economic growth will fail to tackle poverty in the country.

A2015 0xfam report, A Dangerous Divide - the State of Inequality in Malawi, ${ }^{5}$ shone a spotlight on the growing problem of inequality. This new paper presents a vision, roadmap and policy recommendations for a more inclusive, equitable and prosperous Malawi. It recognizes that inequality is not inevitable but the result of policy choices made by those with power. The paper shows that to leave no one behind and get on track to achieve the Sustainable Development Goals (SDGs), the government must commit to policies which prevent the country's elites from appropriating the benefits of economic growth and instead ensure that benefits are redistributed to all. Breaking out of slow and unequal growth requires government, decision makers, development partners and institutions to work for citizens, especially for those living at the margins, rather than serving powerful vested interests within and outside of Malawi. The success of the roadmap hinges on five pillars:

1. Transparent and accountable government and institutions, and tackling corruption, replacing the political capture of policy making by a powerful minority with inclusive political and economic institutions.

2. A real focus on women's economic empowerment and gender equality, with an emphasis on the social and cultural norms that act as a brake on progress.

3. Policy and investment to improve livelihoods of the poorest women and men, delivering equitable growth, especially in agriculture.

4. Raising public revenues more progressively, notably from wealthy individuals, domestic and foreign businesses, to reduce inequality and redistribute income; and ensuring sufficient and quality international aid for the short and medium term.

5. Investing in universal, quality, free public services, such as healthcare and education, that benefit everyone in society, offer social protection for the poorest and dramatically reduce inequality.

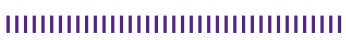

MALAWI IS ONE

OF THE POOREST

COUNTRIES IN THE

WORLD, WITH 70\%

OF THE POPULATION

LIVING ON LESS

THAN \$1.90 A DAY.

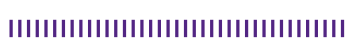


Closing the divide in Malawi

How to reduce inequality and

increase prosperity for all

In pursuing this roadmap, two major realities need to be confronted: institutional and policy failures that have in effect prevented the rural poor in particular from escaping poverty; and major governance shocks, including recession and the 'Cashgate' corruption scandal, that have undermined growth and left a considerable dent in public finances.

Figure 1 A roadmap to tackle inequality in Malawi

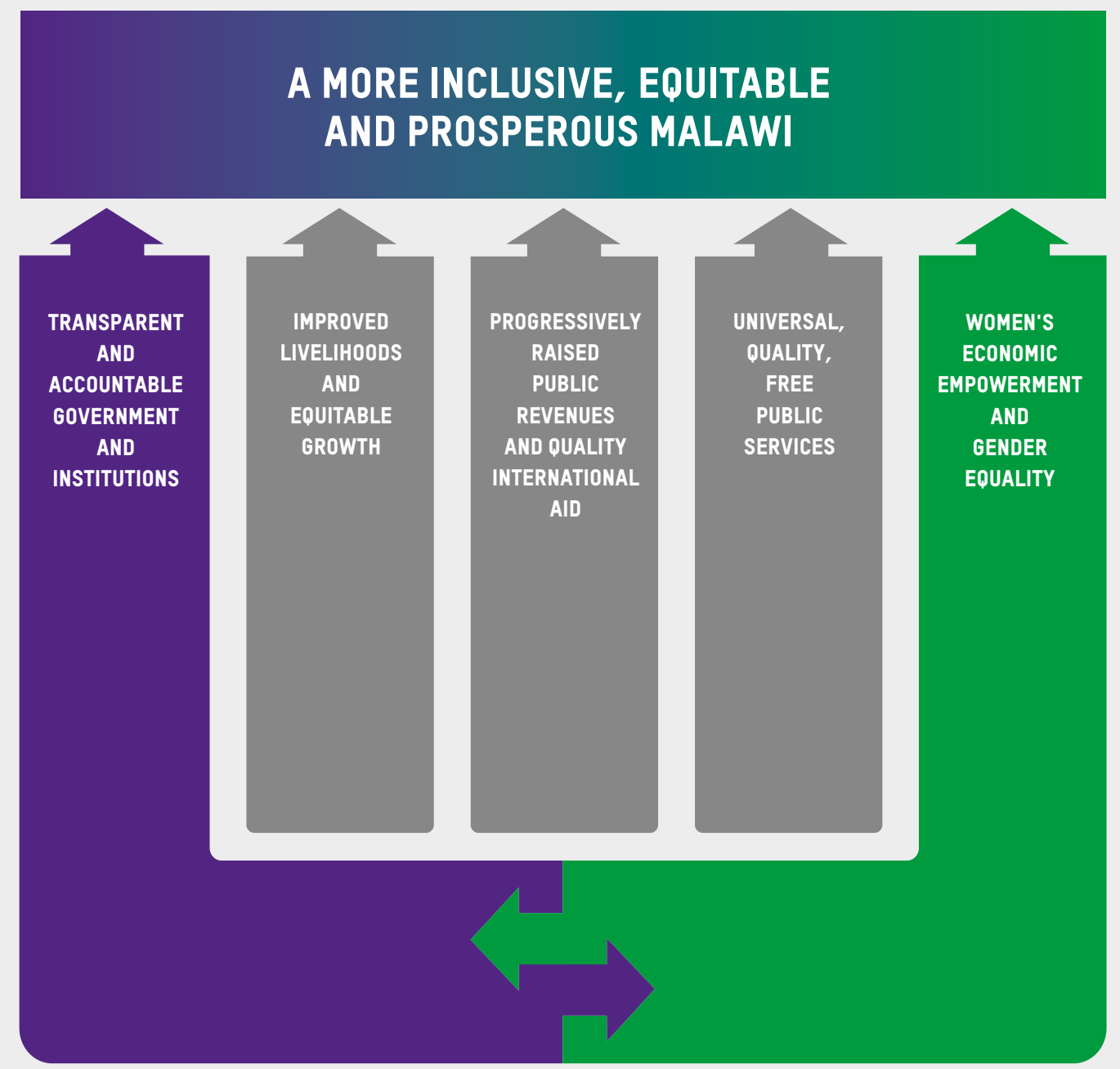


Closing the divide in Malawi

How to reduce inequality and

increase prosperity for all

\section{MALAWI'S INEQUALITY CRISIS IN CONTEXT}

Inequality between the richest and the rest in Malawi has continued to rise markedly, with poverty remaining extreme and endemic. ${ }^{6}$ Climate change is compounding the challenges, with recent droughts and floods likely to have worsened poverty, resulting in one in three Malawians relying on humanitarian assistance in $2016 .^{7}$

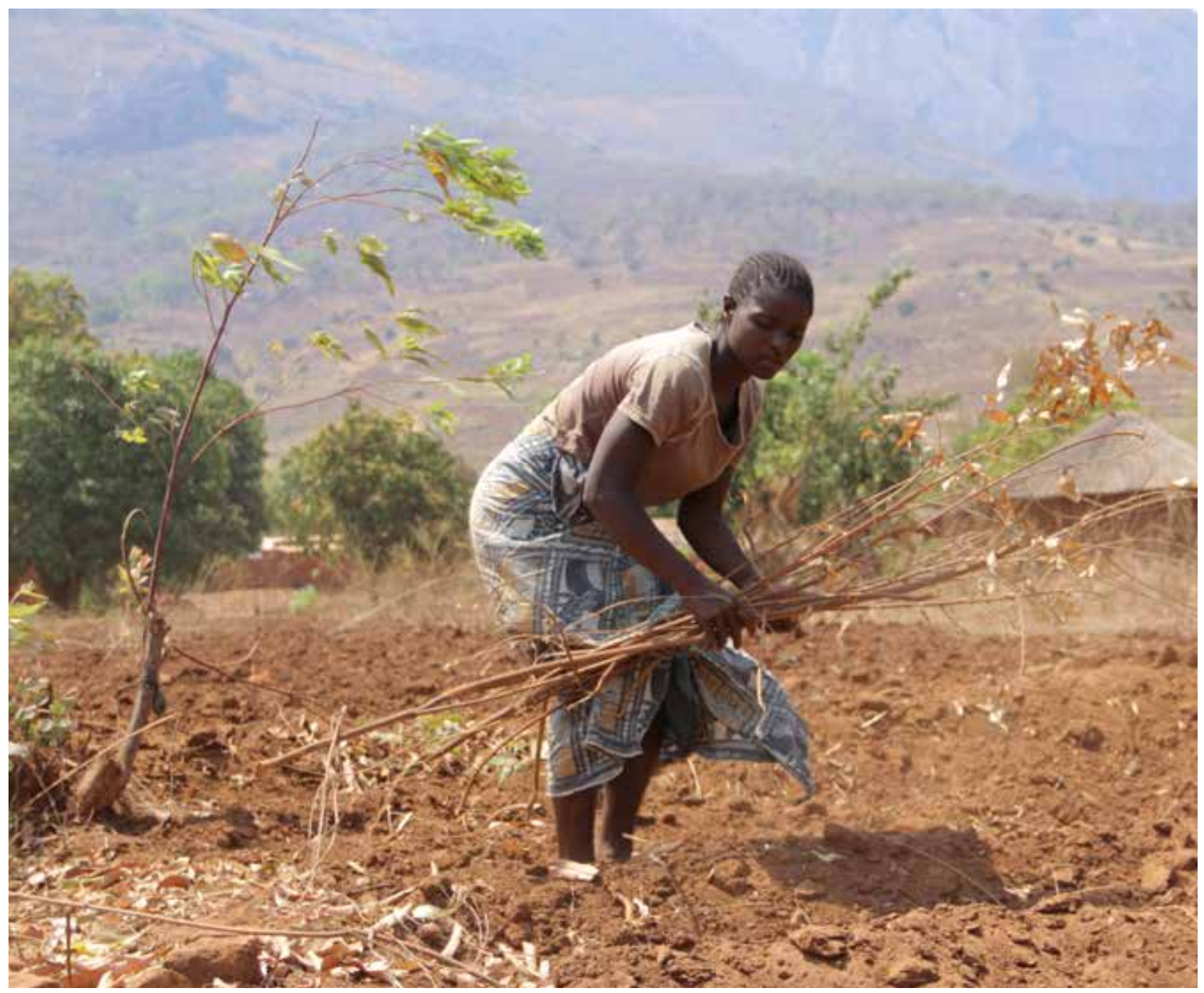

There has been important progress in some aspects of human development, notably the under-five mortality rate falling by 50\% (2004 to 2015) . ${ }^{8}$ However, increasing economic inequality is undermining hard-fought progress. At the bottom end of the scale, poverty increased between 1997 and 2010. ${ }^{9}$ About half of the Malawian population was living below the national poverty line in 2010-11, and more than $70 \%$ below the $\$ 1.90$ international poverty line. ${ }^{10}$ The most recent household survey points to worsening food insecurity - with $73 \%$ of the population not having enough food in the 12 months running up to the survey, and a decline since 2010 across other indicators of poverty such as access to adequate housing. ${ }^{11}$

\section{$\Delta$}

The 2015-2016 El Niño drought that hit hard on small scale farmers like Enipher Nkotima affected parts of southern and central Malawi. Photo: Eidson Chagara/Oxfam in Malawi 
Closing the divide in Malawi

How to reduce inequality and

increase prosperity for all

Economic inequality also compounds inequalities between men and women. Malawi is one of the world's worst countries for the position of women and girls, slipping 20 places in the latest Global Gender Gap rankings. ${ }^{12}$ Gender inequality and discrimination is estimated to cost Malawi $\$ 100 m$ in lost agricultural productivity alone.

Malawi has experienced on average positive growth rates over the last decade, but growth per capita has been negligible, and income growth neither pro-poor nor inclusive - in fact growth was regressive over the 2004-5 to 2010-11 period, with real incomes of the richest increasing and those of the poorest decreasing. ${ }^{13}$

Figure 2 Annual average consumption growth by decile 2004-2010

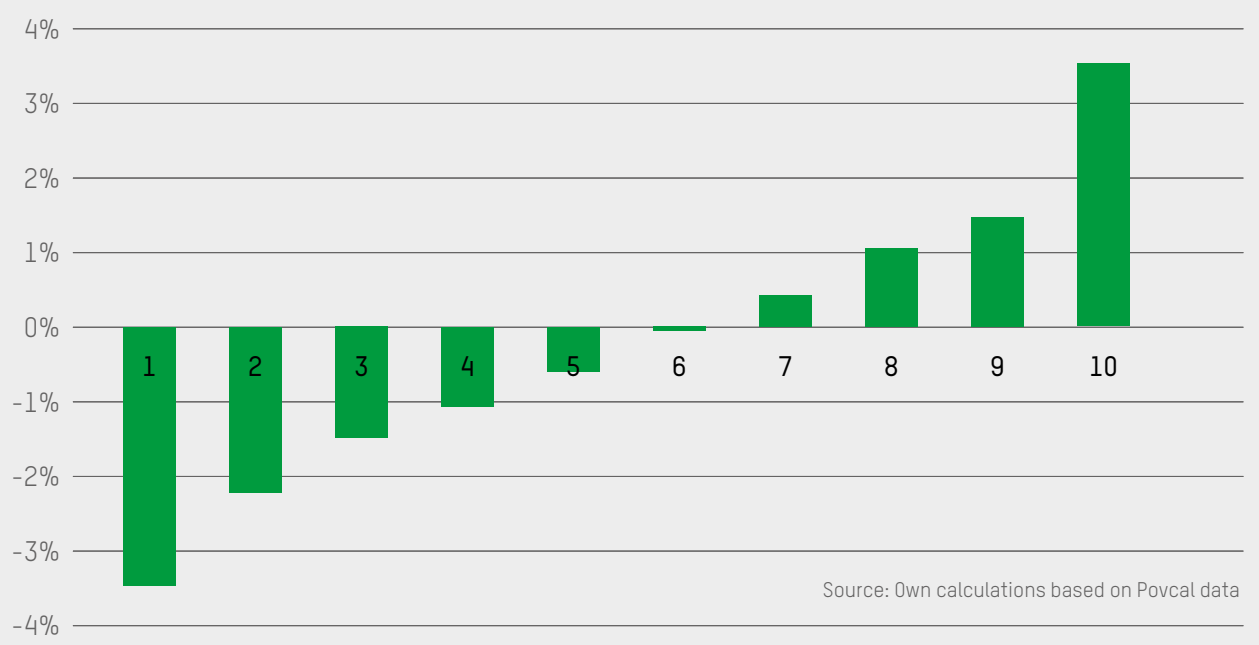

\section{A CLEAR PLAN TO REDUCE THE GAP BETWEEN RICH AND POOR}

Malawi needs a clear National Inequality Reduction Plan to reduce the gap between the richest and the rest of Malawians. Malawi has signed up to SDG 10, to reduce inequality in the country. Clear targets need to be set to reverse the increase in inequality levels and close the gap between rich and poor.

This should be complemented by a robust data collection system to support policy development, target setting and monitoring of progress. 
Closing the divide in Malawi

How to reduce inequality and

increase prosperity for all

\section{TACKLING THE DRIVERS OF INEQUALITY}

In order to meet the targets set out in a National Inequality Reduction Plan, and to fulfil Malawi's commitments under SDG 10, there is a critical need to tackle the drivers of inequality in Malawi. Inequality is not only a question of income and wealth distribution, but also concerns inequality of opportunity, such as unequal access to health and education services. One key driver of economic inequality is power: who makes decisions, and who holds and controls capital and finance. Oxfam's analysis identifies two foremost structural drivers of inequality in Malawi: the political capture of government and public institutions by the country's minority elite; and the pervasive social norms that underpin extreme gender disparities in all aspects of life.

\section{Political capture and corruption - making governance work for citizens}

Malawi is no different to other countries in having elites use their influence on political decision making to further increase their power or make financial gain. ${ }^{14}$ Oxfam regards improvement in the governance of public and political institutions in Malawi as the most critical foundation for reducing inequality and poverty in the country.

Malawi's government has conceded that corruption, which is perceived to be worsening, continues to hamper Malawi's development prospects. ${ }^{15}$ Efforts have been made ${ }^{16}$ to clamp down on corruption, following the Cashgate scandal where a large amount of public money was stolen, although more needs to be done. Given the connections between corruption in Malawi and the global financial system - for example, where unexplained funds are housed in bank accounts outside Malawi ${ }^{17}$ - international actors must work to improve transparency and accountability of this architecture, as well as support asset recovery efforts. The party funding mechanism has been a chief reason for a small wealthy elite gaining so much influence over the political process. The new Political Parties Act is a welcome step towards reform, but it must now be meaningfully implemented. In addition, a deeper reflection on why a culture of corruption persists - by both government and donors - is required.

Public interest and tackling inequalities and poverty in Malawi should be guiding principles of all national policies and strategies, and donor support. Malawians are demanding accountability: ${ }_{i}^{18}$ they must be equipped to hold government and other powerful actors to account.

Oxfam proposes a number of actions, in addition to addressing political party funding, to ensure reforms in the areas of corrupt practices, access to information, assets declaration and political representation of women, as well as government oversight by parliamentary committees. The government and all political parties must commit to a genuine zerotolerance approach to corruption, with all partners working together in a co-created and cross-party compact.

Donors have a critical role to play in providing financial, technical and research support to the government in institution-building, and to civil society organizations (CSOs), with a particular emphasis on CSOs working on women's rights. Donors must also reflect on their own responsibilities in the fight against corruption, including ensuring development assistance adheres to aid effectiveness principles. ${ }^{19}$

\author{
THE GOVERNMENT \\ AND ALL POLITICAL \\ PARTIES MUST \\ COMMIT TO GENUINE \\ ZERO TOLERANCE \\ APPROACH TO \\ CORRUPTION WITH \\ ALL PARTIES \\ WORKING TOGETHER \\ IN A CO-CREATED \\ AND CROSS PARTY \\ COMPACT
}

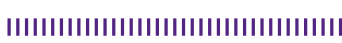


Putting gender equality and women's economic empowerment front and centre Tackling Malawi's deep-seated and worsening gender divide must be a priority for the government and international institutions. The percentage of women who have ever experienced physical violence has increased from $28 \%$ in 2010 to $34 \%$ in $2015-16,{ }^{20}$ almost half of all girls can expect to be married before they are $18,{ }^{21}$ and $93 \%$ of women's labour is unpaid. ${ }^{22}$

There has been some progress on paper, including constitutional reforms outlawing marriage below the age of $18 .^{23}$ Malawi has also shown rapid progress is possible, by achieving gender parity in primary education. ${ }^{24} \mathrm{However}$, far more action is needed to close Malawi's gender divide in access to public services, in the quality of women's participation in productive sectors (like agriculture and mining), and in their access to decent and equally paid work. Fiscal systems need to be sensitive to gender to ensure fairness, with public resource mobilization and spending policies responding to women's needs, and creating incentives and revenues to further reduce and redistribute the heavy unpaid care load shouldered by women and girls.

Critically, Malawi must address the social norms that are still undermining the more progressive gender and women's rights policies, preventing progress and even contributing to rising cases of violence against women and girls.

A national plan should set out how Malawi will achieve SDG 5 on gender equality and women's empowerment. Structural drivers that could be transformative if tackled effectively include:

- Increasing women's voice, representation and independence.

- Closing the gender gap in ownership and control over assets, including ensuring that recent land reforms work for poorer women.

- Fully implementing measures to tackle violence against women and girls.

- Investing further in care services, infrastructure and time and labour saving devices to address the levels of unpaid care work falling on women and girls.

\section{MAKE THE ECONOMY WORK FOR EVERYONE}

Malawi must start managing its economy to deliver growth which is transformative for all people. To achieve this, it is essential that the government delivers on the priority areas identified in the forthcoming Malawi Growth and Development Strategy III (MGDS III), striking the right balance between the essential role of the state and the need to expand the private sector. For this, the rapid liberalisation of agriculture of the past - and removal of state involvement, which pushed many into poverty, must be avoided.

At the same time, efforts should go into achieving greater government and public institution accountability; regulating business to work in the interests of producers and workers; building resilience and environmental sustainability; promoting the empowerment of women; and working towards more progressive domestic resource mobilization to invest in good quality public services for all. It is vital that these policies are specifically designed and implemented to make the MGDS III work for all Malawians.
IIIIIIIIIIIIIIIIIIIIIIIIIIIIIIIIIIIII

"IF YOU INVEST IN A

GIRL OR A WOMAN,

YOU ARE INVESTING

IN EVERYBODY

ELSE."

MELINDA GATES, CO-CHAIR,

BILL AND MELINDA GATES

FOUNDATION

IIIIIIIIIIIIIIIIIIIIIIIIIIIIIIIIIIIIIII
IIIIIIIIIIIIIIIIIIIIIIIIIIIIIIIIIIIIII

MALAWI MUST

START MANAGING

ITS ECONOMY

TO DELIVER

GROWTH WHICH IS

TRANSFORMATIVE

FOR ALL PEOPLE.

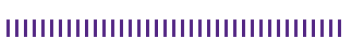


Closing the divide in Malawi

How to reduce inequality and

increase prosperity for all

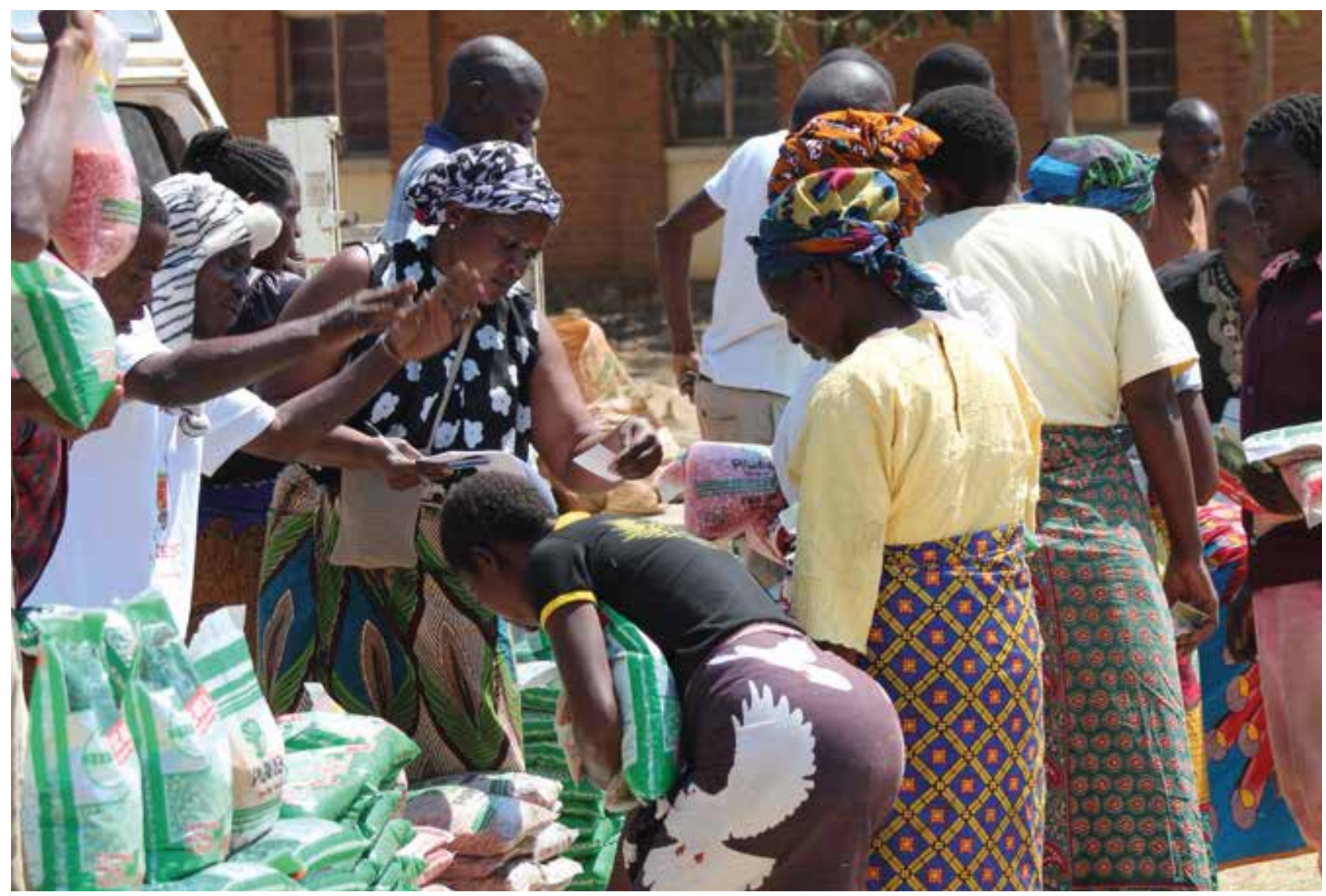

Achieving robust agricultural growth that benefits all

As the backbone of Malawi's economy, agriculture sector performance is uniquely significant for the country's economic growth and reduction of social and economic inequalities and poverty - especially in rural areas.

Most rural Malawians are engaged in farming ${ }^{25}$ and especially subsistence farming. These farmers, and especially women farmers, are highly susceptible to extreme weather, as well as having limited options in terms of accessing additional land, buying fertilizers, seeds or tools and getting technical advice. This sector operates alongside a large farming estates sector, almost entirely export-focused, which has long been the main recipient of state support without creating prosperity for the majority of the rural population.

There is a clear case for a massive, government-led investment, supported by donors, in smallholder farming and supporting infrastructure that works for women and men in a context of volatile weather patterns. Closing the gap in productivity between men and women farmers alone is estimated by the World Bank and others to be worth an additional $\$ 100 \mathrm{~m}$ per year or $7.3 \%$ of annual crop output in Malawi. ${ }^{26}$ Investment is needed in subsidising inputs, ensuring supply of maize and smoothing prices, extension services, infrastructure and technologies that reach the most deprived communities and groups, and the most remote areas of the country, and that are demonstrably improving climate resilience. State support to small and marginal farmers must not be replaced, but rather improved and complemented, by social protection interventions. These initiatives would also support the expansion of the rural non-farm sector, and with it economic diversification and job creation.
$\Delta$

There needs to be greater effort in regulating business to work in the interests of producers and workers. Photo: Watipaso Kaliwo/Oxfam in Malawi 
The 2016 Malawi National Agricultural Policy and draft MGDS III, while acknowledging these issues, need stronger and clearer provisions aimed at overcoming the disparities that exist between smallholder farmers and large estates, concentrating on rebalancing the policy environment in favour of small-scale actors. Additional steps that are needed include:

- Putting greater emphasis on the realities and needs of small and marginal farmers, so that realistic pathways to employment opportunities can be identified.

- Increasing public investment, including in infrastructure and interventions to secure real improvements in land tenure.

- Investing in the employment of new government extension agents, of whom the majority should be women, to help improve farming techniques, reduce vulnerability and increase yields.

- Creating an enabling environment for and encouraging private sector investment in smallholder farming, processing and the non-farm economy.

- Improving the Agricultural Development and Marketing Corporation (ADMARC) and Farm Input Subsidy Programme (FISP), with a specific focus on smallholder farmers and particularly women farmers in very remote areas.

- Securing transparent and open competition around agricultural contracts and stateowned operations.

\section{Work and wages - creating decent jobs and more pay}

The most effective and durable way to achieve inclusive and equitable growth is through the creation of safe and remunerable employment opportunities for all. This is paramount for Malawi, where access to decent paid work is not inclusive and is not a driver of poverty reduction. Instead, the greatest majority of the population is employed in the informal sector, with about $60 \%$ in precarious employment. ${ }^{27}$

A third of all workers in rural areas are in paid employment, usually as agricultural workers on large estates, often complementing their own farm earnings. Their wages, even if complying with the national minimum wage, are often below the poverty line. ${ }^{28}$

Within the formal sector, there is evidence of a steep remuneration scale, leaving Malawi with the largest wage gap between the lowest- and highest-paid jobs among Southern African countries in 2010: executives were earning 107 times more per month than the lowest-paid workers. ${ }^{29}$

Women are highly economically active, but are over-represented in the most unstable, lowest-paid and lowest-skilled agricultural and non-agricultural rural work, ${ }^{30}$ as well as in unpaid care work. Overall, women face greater difficulty translating their labour into paid work.

MGDS III's goal of achieving a productive, competitive and resilient nation will require a clear focus on creating more and better employment for all and ensuring that no one is left behind, with particular attention paid to women, young women and men, and people with disabilities. Integrating the informal sector and making it central to the strategy's delivery should be paramount. Notably, this includes:
IIIIIIIIIIIIIIIIIIIIIIIIIIIIIIIIIIIII

MALAWI NEEDS

STRONGER

AND CLEARER

PROVISIONS AIMED

AT OVERCOMING THE

DISPARITIES THAT

EXIST BETWEEN

SMALLHOLDER

FARMERS AND

LARGE ESTATES

IIIIIIIIIIIIIIIIIIIIIIIIIIIIIIIIIIIIIII

|IIIIIIIIIIIIIIIIIIIIIIIIIIIIIIIIIIIIII

THE WAGES OF

AGRICULTURAL

WORKERS, EVEN IF

COMPLYING WITH

THE NATIONAL

MINIMUM WAGE, ARE

OFTEN BELOW THE

POVERTY LINE.

IIIIIIIIIIIIIIIIIIIIIIIIIIIIIIIIIIIIIII 
Closing the divide in Malawi

How to reduce inequality and

increase prosperity for all

- The provision of special services to workers in the informal economy, that are responsive to the specific needs of and responsibilities falling on women and girls; and steps towards the recognition of informal jobs and the inclusion of informal workers in legal frameworks regulating work conditions, with a focus on the most precarious work, on women, and on small and medium enterprises.

- Ensuring that the minimum wage matches the living wage, and that the minimum wage is enforced in both the formal and informal sectors. Also, establishing in all sectors of employment - including special economic zones - social protection floors, minimum working conditions, childcare provisions, living wage levels, macroeconomic policies geared towards full employment, and re-regulation of the informal sector.

\section{FISCAL JUSTICE: THE FAIR APPROACH TO REDUCING INEQUALITY}

A well-designed tax system that redistributes wealth and enables spending on public services is one of the most effective ways for a government to reduce inequality and poverty, while sustaining growth. ${ }^{31}$ Malawi is constrained by its poor capacity and flexibility in raising additional public income from taxation, as well as by the structure of its economy, which results in a narrow tax base. The fiscal position has been improving in the last year, but remains unable to match expenditure demands.

\section{Public finance}

Domestic resource mobilization alone will not be sufficient to tackle poverty and inequality in Malawi. Malawi's tax system is already relatively progressive. According to Oxfam's 'Commitment to Reducing Inequality Index', 32 Malawi is ranked number one among lowincome countries in terms of progressive structure and incidence of tax. Nevertheless, more can be done to increase equity and collect more revenue from taxation, through:

- Avoiding a rapid increase in revenue from regressive forms of taxation, as this shifts the burden of taxation on to the poorest, increasing inequality rather than reducing it. The VAT system can be made more progressive by exempting essential items and putting a higher rate on luxury items and real estate.

- Adjusting direct taxes, with potential to better use personal income tax to redistribute income by raising the bottom income tax threshold towards the recommended rate of $1 \%$ of GDP per capita, and adding a new higher tax bracket for the highest $10 \%$ earners. More can also be done to raise more tax revenue from Malawi's wealthiest residents, including by introducing capital gains tax.

-Taxing corporations: There is also potential to increase tax revenues by reducing large tax exemptions and deductions afforded to corporations and individuals. Overall, tax expenditure (the sum of exemptions and deductions) in Malawi amounts to 2.2\% of GDP, which is nearly equal to what is spent on the health sector (2.45\% of GDP in 2015). ${ }^{33}$ More revenue could be raised from foreign companies operating in Malawi by introducing more balanced bilateral tax treaties, as current treaties limit Malawi's ability to tax foreign companies. Important corporate tax revenues are also highly likely being lost through profit shifting out of Malawi by foreign corporations. While it is difficult to know exactly how much is being lost this way because these flows are difficult to capture, current best estimates stand at $\$ 90 \mathrm{~m}$ for 2013 , or $2 \%$ of GDP. ${ }^{34}$ Repatriating these revenues depends largely on the adoption of policies by the Government of Malawi, as well as bilateral negotiations with some foreign governments to ensure that companies publish financial reports of their operations in Malawi, alongside coordinated global action on tax dodging.

|IIIIIIIIIIIIIIIIIIIIIIIIIIIIIIIIIII

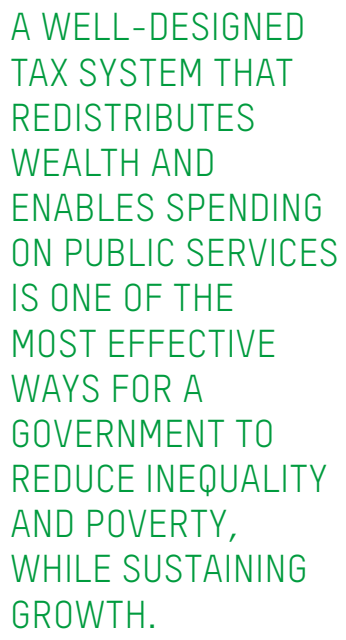

IIIIIIIIIIIIIIIIIIIIIIIIIIIIIIIIIIIIII 


\section{Closing the divide in Malawi How to reduce inequality and \\ increase prosperity for all}

\section{Extractives}

The extractives sector is a potential and very progressive source for increased revenue mobilization, but anticipated revenue is frequently not realised and the benefits are most often not palpable for mining communities, and especially for women. Pursuing mining as a revenue source can fuel inequality if it is poorly regulated and the resulting revenues are captured by a few and not fairly shared with communities.

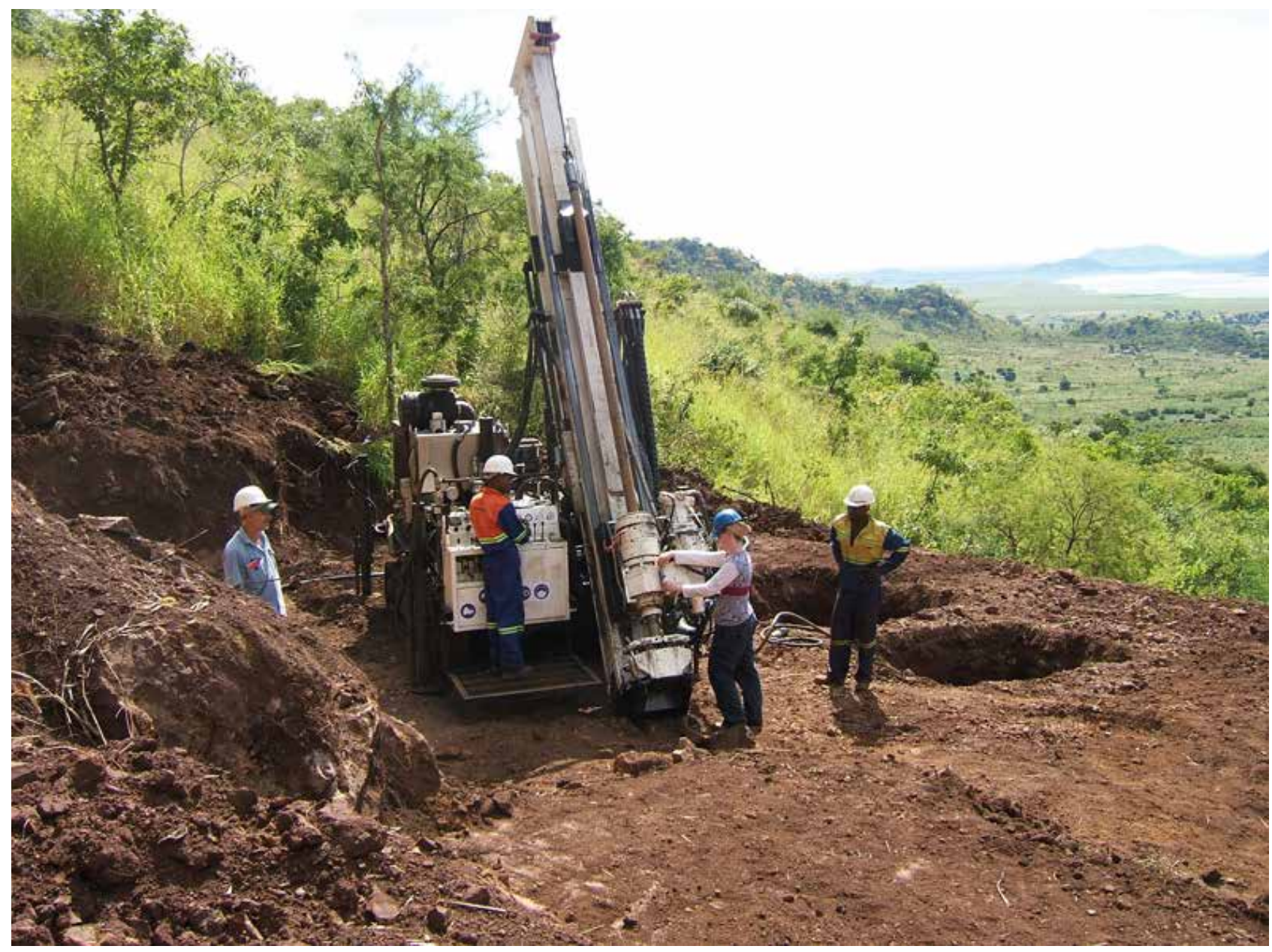

In Malawi, the share of non-tax revenues to the national budget in $2015 / 16$ was only $2 \%$ of GDP, 35 one of the lowest rates among Southern African countries and falling short of the government's expectations. While the potential offered by revenues from extractives could be pursued, experience from mines like Songwe Hill shows that such revenues are unlikely to be 'game changing', and the government should not compromise other development objectives for the sake of mining.

In committing to attract investors in the minerals sector and to retain a substantial amount of revenue in Malawi, the government needs to ensure that companies pay what they owe, backed by legislation and monitored through routine audits. It needs to put in place mechanisms which ensure that when incentives are created to attract foreign investment in mining, revenues are raised from the profits made by these companies and redistributed to all, especially the mining communities.
Mkango mining drill pad on Songwe Hill, Phalombe, Southern Malawi. Photo: Mkango Resources Limited, www.mkango.ca 
Closing the divide in Malawi

How to reduce inequality and

increase prosperity for all

\section{International aid}

Malawi relies heavily on international aid as a source of public finance. ${ }^{36}$ Even though Malawi should ultimately transition away from dependence on donor finance, the country will continue to need substantial aid in the medium term - more than it is currently receiving to maintain public expenditure. It will also continue to need aid to help explore and develop future alternative revenue streams, as well as to support climate change adaptation and mitigation.

Given the scale of need and the historic and continued high level of aid, donors are both very powerful - and highly responsible - for tackling poverty and inequality in Malawi. Aid must be channelled effectively to ensure government systems are not undermined, and invested in sectors that support equitable and sustainable growth. Sadly in the last five years the quality of donor aid has fallen (figure 3). In addition, the suspension of direct donor aid has contributed to government adoption of regressive policies that have driven up inequality and hurt the poor. This includes the removal of exemptions for VAT on basic goods and food used by the poor and the imposition of types of user fees in hospitals which have had a negative impact on the health of the poorest.

Figure 3 Overseas development aid (ODA) performance against key measures of aid effectiveness

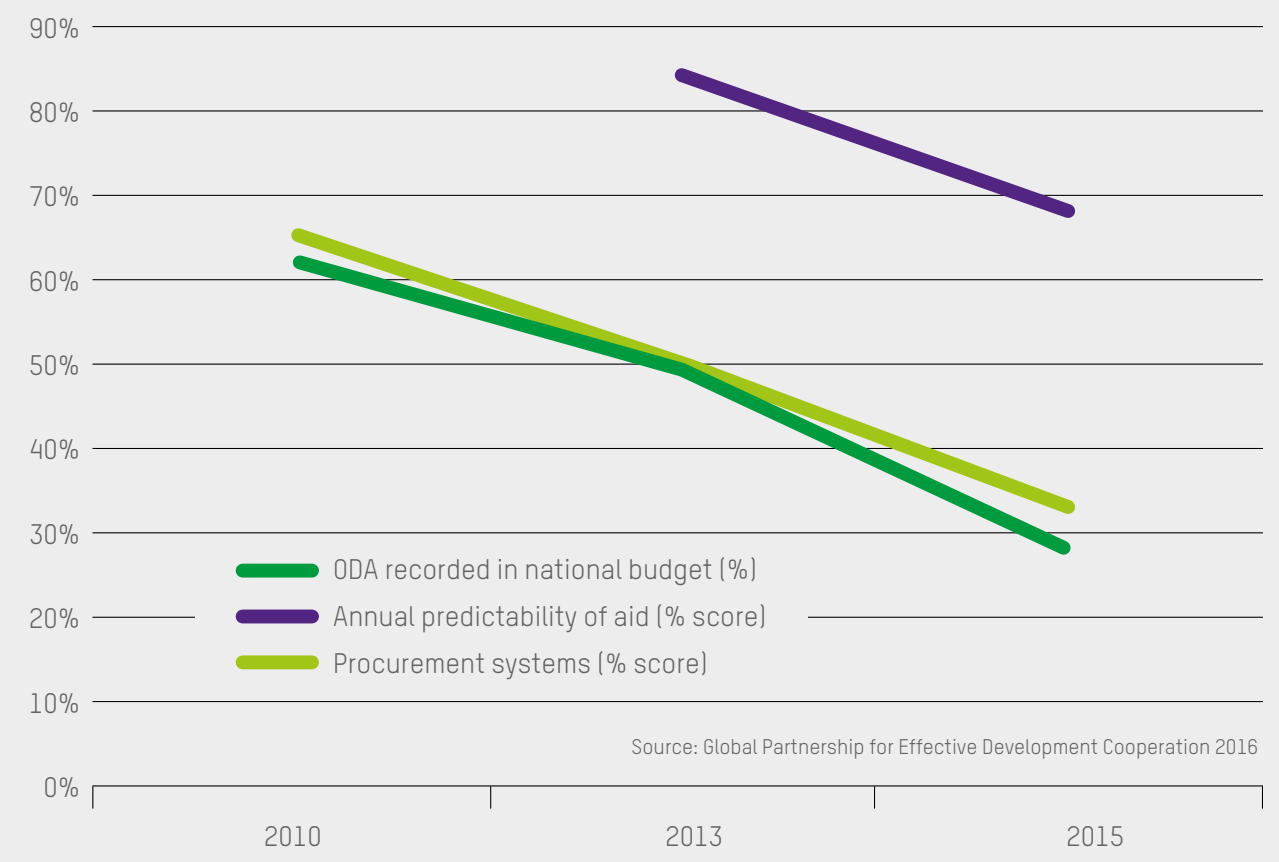


- Aid needs to be targeted at strengthening governance of public institutions so they are accountable to all citizens.

- Aid needs to support civil society and citizens' efforts - particularly those of women's and marginalized communities' groups - to actively engage in public (including budgetary) decision making and to monitor government performance, holding it to account.

- Aid needs to support the government to ensure good quality, free universal public healthcare and education, and provide social protection.

In response to the Cashgate scandal, donors have suspended most budget support grants since 2013. ${ }^{37}$ Side by side with support to government in improving its public finance management systems and their application, restoring budget support is the most urgently needed action donors should take to enhance aid quality and ensure funding of critical government interventions and services.

Donors must also urgently increase aid levels to Malawi for the medium term, particularly in light of its debt servicing obligations. Indeed, by 2016, Malawi's external debt payments were around $\$ 200 \mathrm{~m}$, using up over $18 \%$ of government revenue and consuming significantly more funds than in the entire health budget. 38 Malawi needs grants from donors, not the added burden of servicing loans to banks and government lenders. ${ }^{39}$

\section{Public spending}

Progressive and effective public spending is the other side of the fiscal justice coin. Spending on free, public services benefits everyone, but provides greater benefits to the poorest. ${ }^{0}$ Oxfam proposes three top priorities for increased public expenditure in Malawi: healthcare, education and social protection.

\section{Healthcare}

Malawi has made a welcome commitment to achieving UHC - where all people access the healthcare they need without facing financial hardship - as part of the SDGs. However, this is currently a major challenge and requires ambitious action. The health sector is steeped in a funding crisis and being starved of urgently needed public finance..$^{41} \mathrm{~A}$ quarter of health facilities in Malawi have neither a functioning client latrine or ambulance, and a similar proportion of medical equipment is out of service. ${ }^{42}$ Almost half of Malawi's health-worker positions are vacant. ${ }^{43}$ While there is much to be done to achieve UHC, quality public health services that are free at the point of use are a powerful way to reduce income and gender inequalities and tackle poverty.

Oxfam urges the following actions to put Malawi on the path to achieving UHC.

Abolish regressive user fees: The health sector has been conducting a dangerous experiment with user fees in healthcare in recent years. User fees for treatment, care and services have proven to be the most regressive and damaging way to generate funds for health system costs. User fees rarely contribute more than $5 \%$ to health budgets. ${ }^{44}$ The Government of Malawi must urgently abolish user fees across its facilities, with immediate suspension of hospital bypass fees and existing fee-paying wards. Combining this with increased investment in comprehensive quality primary healthcare will be a more cost-effective and fairer route for Malawi to achieve its ultimate ambition of UHC and ensure it leaves no one behind. Donors must also strongly challenge this dangerous and harmful policy and should restore adequate levels of funding to government health systems.
IIIIIIIIIIIIIIIIIIIIIIIIIIIIIIIIIIIIII

MALAWI HAS MADE

A WELCOME

COMMITMENT

TO ACHIEVING

UNIVERSAL

HEALTHCARE.

HOWEVER, THE

HEALTH SECTOR

IS STEEPED IN A

FUNDING CRISIS AND

BEING STARVED OF

URGENTLY NEEDED

PUBLIC FINANCE.

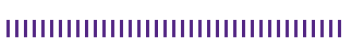




\section{Closing the divide in Malawi How to reduce inequality and increase prosperity for all}

\section{BOX 1. THE PERSONAL COST OF HOSPITAL BYPASS FEES}

'I am Mrs Mwale and I live in Mzuzu. I am a mother of five and a vegetable vendor. My third-born child died of malaria when she was six years old. In May this year [2015], my last-born child had malaria. I went to our Central Hospital (Mzuzu) for medical attention. I was told I should pay MK 1,500 or go to Mzuzu Health Centre. I only had MK 500 on me.

Knowing that there are very long queues at the health centre, I called my friends and borrowed the money so that I could have my child attended. I didn't want to go and queue and end up losing her. I lost one before and I didn't want to go through the pain again. I was helped out by my friends, paid the MK 1,500 bypass fee, and the child was attended.

My business was, however, not going well. I failed to raise money to repay the friends who helped me. I ended up selling my bicycle that we were using for the vegetable vending business to pay off my debt. I am struggling to make ends meet, but I am happy I have my child with me. With God's grace, I will make some more money and buy another bicycle.' ${ }^{45}$

Beyond state-run facilities, the government must also implement the recently planned expansion of Christian Health Association of Malawi (CHAM) service-level agreements, to ensure an essential health package can be provided for free by CHAM facilities when there is no nearby government clinic. ${ }^{46}$

Restore effective public financing: The government must urgently increase public spending on health and meet the Abuja commitment to invest 15\% of total government spending on health. Public finance generated by domestic revenue mobilization is the best way to fund the health system in the long term. ${ }^{47}$ But even with increases in collection of domestic resources, Malawi doesn't have enough resources to achieve healthcare for all. ${ }^{48}$ There can be no escaping that international aid to the health sector must also be increased and sector budget support restored, or an alternative on-budget aid model implemented at a minimum. Without an increase of on-budget aid to finance the health sector, it is the poorest who will suffer most with likely further increases in punishing out-of-pocket payments for health, and further fragmentation and deteriorating quality across the health system.

Rule out the introduction of a National Health Insurance Scheme (NHIS): Introducing an NHIS would exacerbate inequality and leave the poorest behind in accessing healthcare in Malawi. Challenges with enrolment and prohibitive costs are commonplace in insurance schemes in other countries such as Ghana, where schemes exclude a large proportion of the population..$^{49}$ Evidence from other countries has shown that a NHIS scheme is unlikely to raise significant additional revenues for health, especially outside of the formal sector. ${ }^{50}$

Investing for equity, efficiency and quality: Beyond increased financing, interventions are needed that improve equity, efficiency and quality in the health system, clamping down on drug pilferage, and making healthcare responsive to the needs of Malawi's women in particular.

IIIIIIIIIIIIIIIIIIIIIIIIIIIIIIIIIIIIII

THERE CAN BE NO

ESCAPING THAT

INTERNATIONAL AID TO THE HEALTH SECTOR MUST ALSO BE INCREASED.

IIIIIIIIIIIIIIIIIIIIIIIIIIIIIIIIIIII

\section{Education}

Malawi has made enormous progress since the 1990s in increasing access to public education, especially at the primary level. It was one of the first countries to abolish user fees for primary education in Africa, a move which saw one million new students go to school 


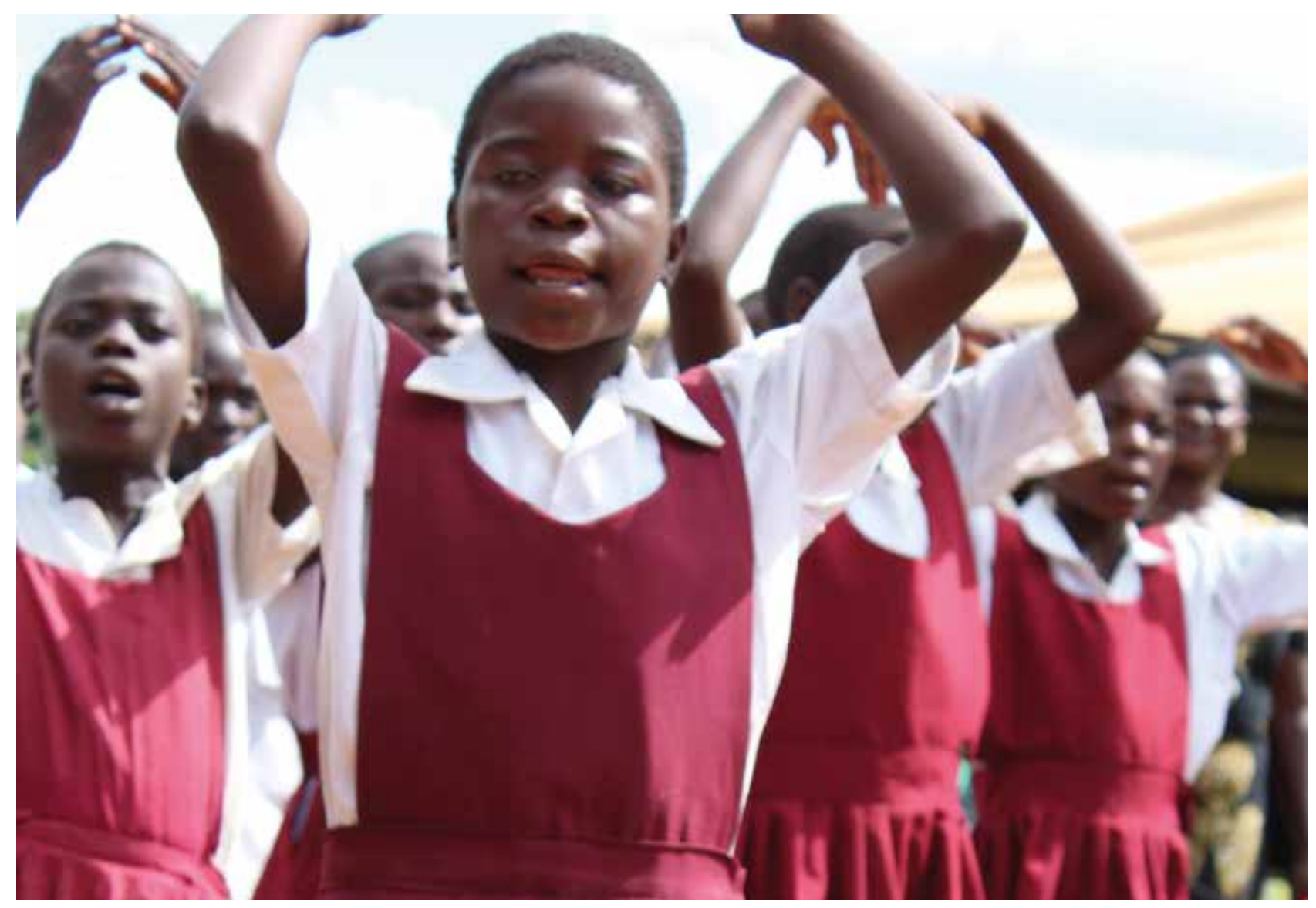

for the first time. ${ }^{51}$ In the early 1990s, the richest children were almost twice as likely to go to primary school as the poorest. Just a few years after the removal of fees, this gap was virtually eliminated. ${ }^{52}$ Today, the gap between urban and rural areas is also minimal. ${ }^{53}$ Even more impressively, Malawi has now achieved gender parity in primary school attendance. ${ }^{54} Y e t$ despite these huge gains, there are still serious concerns around the quality of both primary and secondary education, and access for the majority of poor Malawians beyond primary level. ${ }^{55}$ More well-off families send their children to fee-paying private schools, where the quality of teaching is often better, leading to a dynamic that entrenches the inequality divide. ${ }^{56}$

Oxfam stresses that action should be taken in the following areas to address inequalities in education.

Spending on education should rise from its current $17-18 \%$ of the national budget to at least $20 \%$, in line with international targets. ${ }^{57}$ Targets must be met, not only committed to, with no diversion of funds to other government departments. ${ }^{58}$

Expanded aid for education is vital, and must be provided as sector budget support. Donors should pool their funds behind government plans, and should contribute to recurrent costs, to ensure adequate numbers of teachers who are paid a living wage.

Teachers are the backbone of improved education and investment in teachers is also vital to tackle Malawi's education quality crisis. More must be done to address the frequent late payment of teachers' salaries, ${ }^{59}$ to train more teachers, and make improvements in infrastructure and teaching resources.

\section{$\Delta$}

Malawi was one of the first countries in Africa to offer free primary school education Photo: Daud Kayisi / Oxfam in Malawi

IIIIIIIIIIIIIIIIIIIIIIIIIIIIIIIIIIIIIII

MALAWI HAS

MADE ENORMOUS

PROGRESS SINCE

THE 1990S IN

INCREASING

ACCESS TO PUBLIC

EDUCATION,

ESPECIALLY AT THE

PRIMARY LEVEL.

|IIIIIIIIIIIIIIIIIIIIIIIIIIIIIIIIIIIIII 
The government must invest more in secondary and tertiary education: Removal of user fees in secondary schools must be a priority policy. Secondary education must also be made compulsory. Investments in teachers and infrastructure will need to be dramatically increased to keep pace with expanded demand. Additional financing of tertiary education, where enrolment is reported as among the lowest in the world, ${ }^{60}$ will also be required. This should include continued high subsidies for students from poorer communities or marginalized groups, especially women, and funding to increase university places.

\section{Social protection}

Malawi's social protection policy framework has been strengthened in recent years, but despite some improvements, Malawi's poverty reduction and social protection system falls short of current and future needs. ${ }^{61}$ Overall, the programmes are not providing sufficient resources to those people they reach, and are not reaching many of the poorest and most vulnerable people at all. In 2015, the Social Cash Transfer Programme reached just half of the $10 \%$ target. ${ }^{62}$ Lack of resources is a major issue: public expenditure on social protection programmes in Malawi is low by international standards, and lower than average for low income countries in Africa.

Malawi needs a more ambitious, large-scale, integrated social protection system, learning from other successful models in Africa. This will require time and capacity building. The social protection provisions included in MGDS III - such as the integration of social protection with agriculture interventions - go in the right direction, but need to be accompanied by the political will and the financial resources to implement them.

\section{CONCLUSION}

Malawi is an extremely poor country with a systemic inequality and exclusion problem, which means most women and men are being left behind. The country faces challenges in radically altering its development path and reducing inequality, including: a large burden of debt, a narrow tax base that hampers increased domestic resource mobilization, a history of corrupt governance of public institutions, and distrusting international development partners who spend their aid outside the government system. These challenges are compounded by a growing population and one that is exposed to the full force of climate change, especially in rural areas.

This paper sets out policy solutions that the government can adopt, supported by donors, civil society and others, to change the course of Malawi's future. At the forefront of change must be efforts to tackle the structural drivers of inequality, in Malawi's case weak governance, capture of policy making by an elite and widespread corruption, as well as pervasive gender disparities. Making the economy work for everyone must be at the heart of all policy, underpinned by free and universal healthcare and education, as well as a scaledup social protection system. Development partners and international institutions must finance and support these priority policies, as opposed to pushing problematic models or undermining government systems through a piecemeal approach to aid.

None of these solutions will work if implemented alone or in a vacuum; they are all dependent on each other, and they all demand close involvement of the people they are meant to reach. The vision we present for a more equal Malawi - where no one is left behind - requires the active participation of women and men from all social groups to shape and drive forward action across the range of interconnected issues.

But it is achievable.
|IIIIIIIIIIIIIIIIIIIIIIIIIIIIIIIIIII

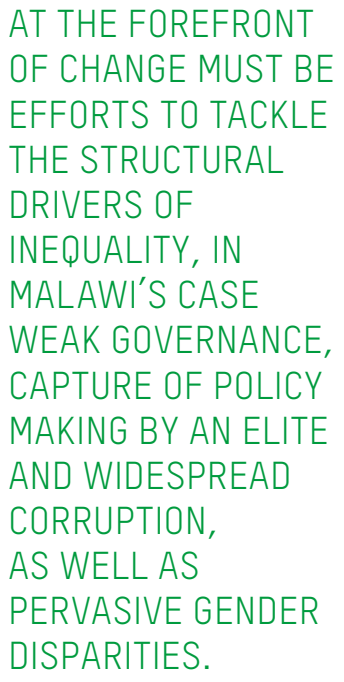




\section{CLOSING THE DIVIDE IN MALAWI}

\section{HOW TO REDUCE INEQUALITY AND INCREASE PROSPERITY FOR ALL}

Malawi is one of the poorest countries in the world, ${ }^{63}$ with $70 \%$ of the population living on less than $\$ 1.90$ a day.$^{64} \mathrm{~A}$ low level of economic development - alongside seemingly regular shocks - has left the nation's finances perpetually constrained. Yet simultaneously, Malawi is home to 10 multi-millionaires, each with a net worth of over $\$ 10 \mathrm{~m}$, and one ultra-highnet-worth individual with a net worth of over $\$ 30 \mathrm{~m} .{ }^{65}$ Malawi has also experienced - albeit volatile - economic growth in recent years, the gains of which are clearly not reaching the majority of women, men and children who remain trapped in poverty.

In 2015, Oxfam released A Dangerous Divide - The State of Inequality in Malawi, ${ }^{66}$ which shines a spotlight on the growing problem of extreme inequality in Malawi. The report highlights the damaging impacts of inequality on Malawi's development, governance and poverty reduction efforts, and inspired a series of public debates eliciting the voices of Malawi's people. From this exchange of ideas, and Oxfam's own research and analysis, we have formulated a roadmap showing the Government of Malawi, international partners and civil society a way out of the inequality crisis.

The purpose of this paper is to present a vision for a more inclusive, equitable and prosperous Malawi, and a roadmap with policy recommendations to get us there. Our vision recognizes that inequality is not inevitable, but the result of policy choices made by those with power. Extreme inequality can be reversed if the government, decision makers, donors and institutions work in the public interest - especially for women and those living at the margins - and not with a view to serving powerful vested interests within and outside Malawi. The roadmap is based on a vision for Malawi where all citizens are at the heart of development, holding government and other decision makers to account for tackling poverty and inequality, and leaving no one behind. The success of the roadmap hinges on five pillars.

1. Transparent and accountable government and institutions, and tackling corruption, replacing the political capture of policy making by a powerful minority with transparent and accountable government and institutions.

2. A real focus on women's economic empowerment and gender equality, especially addressing the social and cultural norms that act as a brake on progress.

3. Policy and investment to improve livelihoods of the poorest women and men and deliver equitable growth, especially in agriculture, rather than serving primarily powerful business interests and land owners or applying failed neoliberal models imported from the World Bank and other donors.

4. Raising public revenues more progressively, notably from wealthy individuals, domestic and foreign businesses to reduce inequality and redistribute income; and ensuring sufficient, quality international aid for the short and medium term that consistently adheres to aid effectiveness principles.

5. Investing in universal, quality, free public services, such as healthcare and education, because they benefit everyone in society - particularly the poorest people and poor women and girls - and dramatically reduce inequality.
IIIIIIIIIIIIIIIIIIIIIIIIIIIIIIIIIIIII

"THE MESSAGE

IS THAT RISING

INEQUALITY IS

DANGEROUS.

IT'S BAD FOR

GOVERNANCE.

WE SEE A

CONCENTRATION OF

WEALTH CAPTURING

POWER AND LEAVING

ORDINARY PEOPLE

VOICELESS AND

THEIR INTERESTS

UNCARED FOR."

WINNIE BYANYIMA, EXECUTIVE

DIRECTOR, OXFAM INTERNATIONAL

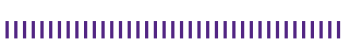

IIIIIIIIIIIIIIIIIIIIIIIIIIIIIIIIIIIII

MALAWI HAS ALSO

EXPERIENCED -

ALBEIT VOLATILE -

ECONOMIC GROWTH

IN RECENT YEARS,

THE GAINS OF

WHICH ARE CLEARLY

NOT REACHING

THE MAJORITY OF

WOMEN, MEN AND

CHILDREN WHO

REMAIN TRAPPED IN

POVERTY.

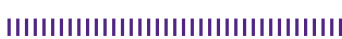


Closing the divide in Malawi

How to reduce inequality and

increase prosperity for all

Figure 4 A roadmap to tackle inequality in Malawi

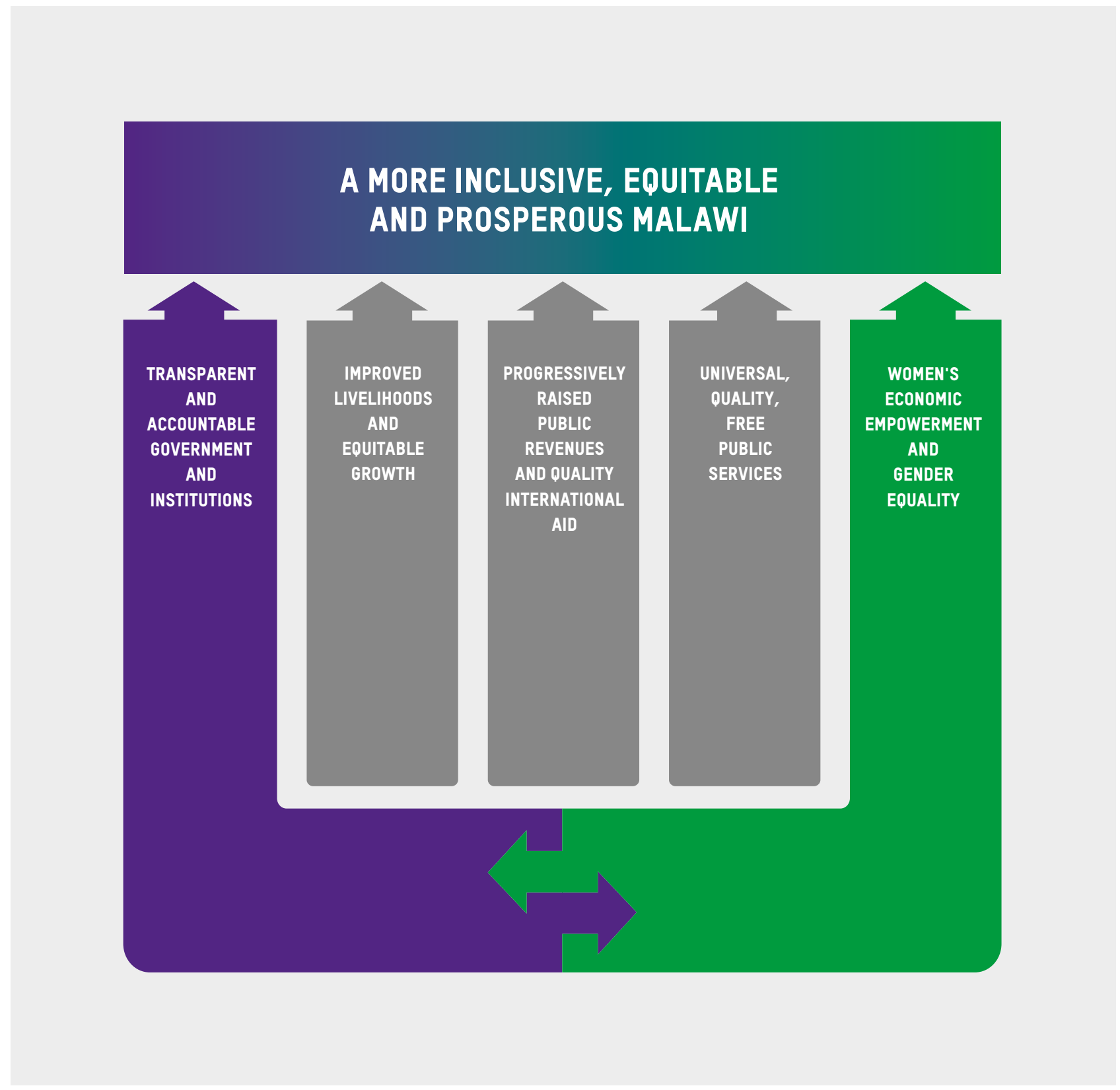

Malawi faces considerable challenges in making progress towards an inclusive, equitable and prosperous economy and society. Firstly, growth that will benefit the majority of Malawi's people depends on a robust and inclusive agricultural sector that is also climate-proof. Growth and productivity in agriculture has been volatile, including in the context of extreme weather. Many of Malawi's agricultural institutions and past policy choices have effectively prevented the rural poor from escaping poverty, and often only served to exacerbate income and gender inequalities. Secondly, there have been major governance shocks, including a policy-induced recession in 2012, followed by the 'Cashgate' corruption scandal of 2013 
Closing the divide in Malawi

How to reduce inequality and

increase prosperity for all

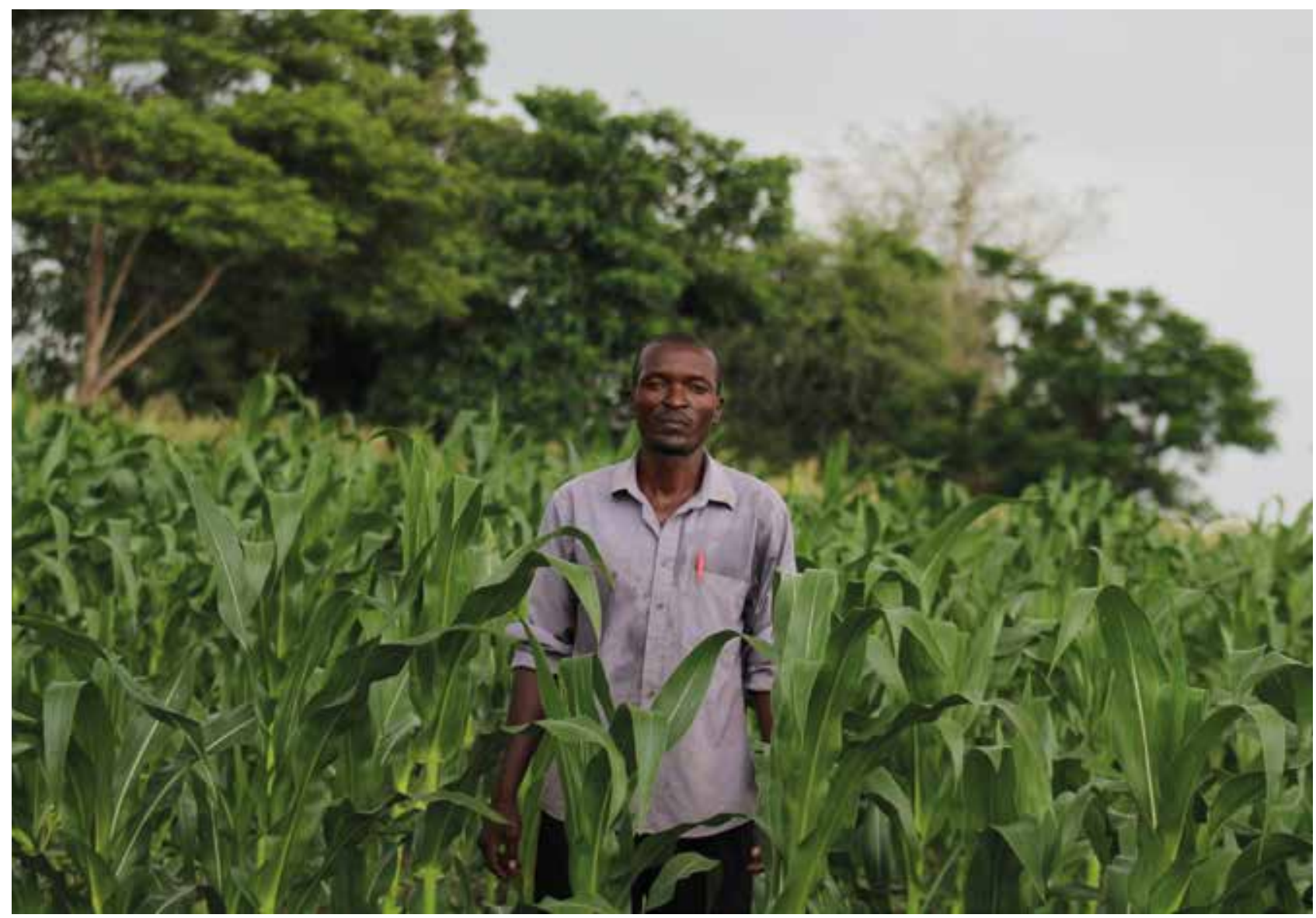

where a large amount of public money was stolen from government accounts. Together, these not only undermined growth but created a considerable dent in public finances and highlighted weaknesses in public financial management; this was compounded by the initial suspension and subsequent shift of a significant share of donor aid to off-budget mechanisms.

With the right financial backing from government and donors, the right prioritization of spending on long-term and sustainable priorities, and genuine political commitment and public accountability, Malawi can stop its inequality crisis in its tracks.

\section{MALAWI'S INEQUALITY CRISIS IN CONTEXT}

Over the last decade, inequality between the richest and the rest in Malawi has continued to rise markedly. At the bottom end of the scale, poverty is increasing: it was higher in 2010-11 than in 1997-98, with a decline of about two percentage points recorded between 2004-05 and 2010-11 (Table 1). About half of the Malawian population was living below the national poverty line in $2010-11$, and more than $70 \%$ below the $\$ 1.90$ international poverty line (Table 1). More worryingly, the same data also showed that $25 \%$ of the population was ultra-poor, meaning people could not even afford to meet the minimum standard for dailyrecommended food requirements. ${ }^{67}$ The latest household survey shows that $61 \%$ of the population experienced very low food security immediately prior to the survey, compared to $32 \%$ in $2010 / 2011 .{ }^{68}$ It also highlights a decline since 2010 across other indicators of

\section{$\Delta$}

A more robust, inclusive and climate-proof agricultural sector will benefit Malawi smallholder farmers. Photo: Daud Kayisi/Oxfam in Malawi

IIIIIIIIIIIIIIIIIIIIIIIIIIIIIIIIIIIII

"THERE HAVE BEEN RISING

INEQUALITIES WITH CONCURRENT CASES OF CORRUPTION AND FRAUD, WHAT IS THE CORRELATION? OR, IS THIS JUST A COINCIDENCE?" PROFESSOR CHIJERE CHIRWA, UNIVERSITY OF MALAWI, CHANCELLOR COLLEGE

IIIIIIIIIIIIIIIIIIIIIIIIIIIIIIIIIIIIII 
poverty such as access to adequate housing. ${ }^{69}$ In a world seeking to end poverty by 2030 , it is staggering that poverty in Malawi remains so extreme and endemic, and is even worsening. Moreover, a World Bank macro-poverty forecast exercise has projected that poverty in Malawi measured by the population living below the international poverty line has barely changed between 2010 and 2016 (70.9\% in 2010 to $69.6 \%$ in 2016). ${ }^{70}$

Climate change is adding yet more challenges. Already, poverty is likely to have been made even worse because of the extensive floods of 2015 , followed by a major drought the following year. The ensuing hunger crisis resulted in over one in three Malawians relying on humanitarian food assistance in $2016 .{ }^{71}$ Around $80 \%$ of the population lives in densely populated rural areas, where most survive by subsistence farming or agricultural work. According to the most recent Household Survey, $78 \%$ of households are involved in rainy season cultivation. ${ }^{72}$ Most Malawians are therefore highly vulnerable to weather shocks.

\section{Table 1 Poverty and inequality indicators}

\begin{tabular}{|l|l|l|l|l|}
\hline & $\begin{array}{l}\text { Headcount Poverty } \\
\text { Index HCPI \$1.90 } \\
\text { Poverty line (\%)* }\end{array}$ & $\begin{array}{l}\text { HCPI National } \\
\text { Poverty line* * \%) }\end{array}$ & Gini* & Palma ratio \\
\hline $1997-98$ & 63.63 & 65.3 & 65.76 & 6.25 \\
\hline $2004-05$ & 73.63 & 52.4 & 39.87 & 1.86 \\
\hline $2010-11$ & 70.91 & 50.5 & 46.12 & 2.56 \\
\hline $\begin{array}{l}\text { * Source: Povcal } \\
\text { **urce: National Statistical Office (2012); National Economic Council (2000). }{ }^{73} \text { The national poverty line in 2011 } \\
\text { was 37,002 Malawian Kwacha (MWK) per person per year }\end{array}$ \\
\hline
\end{tabular}

There has been important progress in some aspects of human development. Large flows of aid made a significant contribution to Malawi making progress towards or achieving four of the eight Millennium Development Goals. ${ }^{74}$ For example, the under-five mortality rate declined from 133 deaths per 1,000 live births in 2004 to 63 deaths per 1,000 live births in 2015. ${ }^{75}$

However, extreme economic inequality is undermining hard-fought progress towards reducing poverty and improving health and education outcomes. Malawi's Human Development Index score drops by almost a third when inequality is factored in. ${ }^{76}$ In 2015 , Oxfam calculated that a further 1.5 million Malawians will be poor by 2020 if nothing is done to tackle inequality. ${ }^{77}$ Economic inequality also compounds inequalities between men and women, and girls and boys. Gender inequality is already worse in Malawi than almost anywhere else in the world, ${ }^{78}$ and the situation is worsening - the latest World Economic Forum Global Gender Gap report has Malawi slipping 20 places in global rankings in one year, from 81 to $101 .{ }^{79}$ Poor rural women in particular will continue to be at the bottom of the pile - and even left further behind - if economic and social inequalities are not addressed.

While economic growth has been volatile over the last decade, Malawi has generally experienced on average positive growth rates: remaining above $5 \%$ since 2007 , apart from 2012, and 2015-16 (as a result of the floods), when it held at 2\% (see Figure 5).
IIIIIIIIIIIIIIIIIIIIIIIIIIIIIIIIIIIIII

"CLIMATE CHANGE

INCREASINGLY

POSES ONE OF

THE BIGGEST LONG

TERM THREATS TO

INVESTMENT."

CHRISTINA FIGUERES, FORMER UN CLIMATE CHIEF

IIIIIIIIIIIIIIIIIIIIIIIIIIIIIIIIIIIIIII
IIIIIIIIIIIIIIIIIIIIIIIIIIIIIIIIIIIIII

EXTREME ECONOMIC

INEQUALITY IS

UNDERMINING HARD-

FOUGHT PROGRESS

TOWARDS REDUCING

POVERTY AND

IMPROVING HEALTH

AND EDUCATION

OUTCOMES.

IIIIIIIIIIIIIIIIIIIIIIIIIIIIIIIIIIIIIII 
Closing the divide in Malawi

How to reduce inequality and

increase prosperity for all

Figure 5 Malawi's pattern of economic growth, 1997-2016

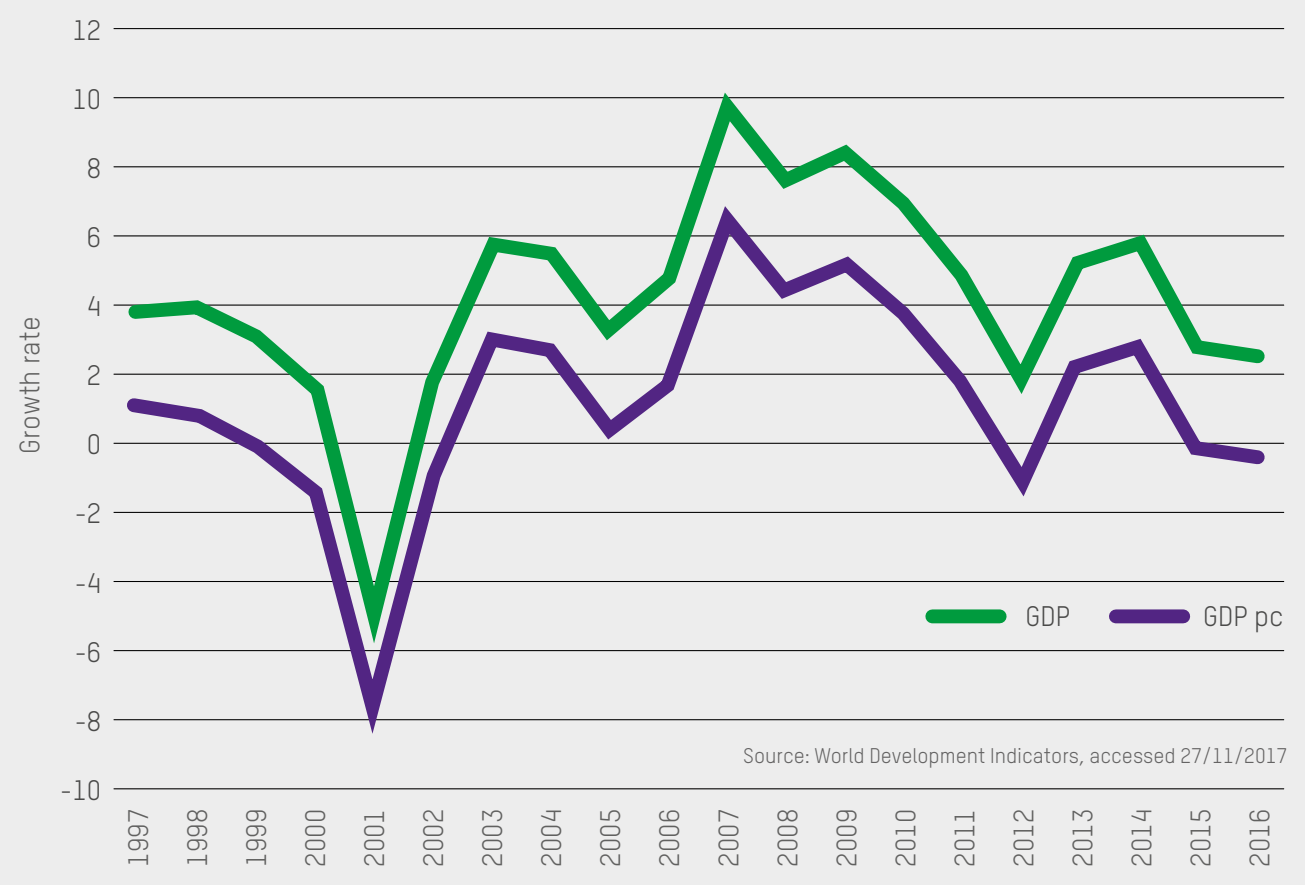

By contrast, growth in income per capita has been negligible in the last two decades: it increased by just \$102 over 18 years, from \$388 per year in 1997 to \$494 in 2015 (see Figure 6). Further, income growth has been neither pro-poor nor inclusive. Between 1997-98 and 2004-5 the country experienced an economic and political crisis which led to a decline in income across all deciles of the population, reflected in an increase in poverty and a reduction of inequality as measured by the Gini coefficient (see Table 1). The government which took power in 2004, strongly backed by World Bank and International Monetary Fund interventions, implemented a number of reforms characterised by economic liberalisation and a reduction in the role of the State. ${ }^{81}$ These reforms contributed to restore macroeconomic stability but benefitted mostly the richest half of the population, and harmed the poorest. In fact, inequality - as measured by the Gini index and the Palma ratio - increased between 2004-05 and 2010-11 (Table 1). Figure 7 shows that growth was regressive in this period: consumption growth was higher for the four top deciles of the population than for the poorest, which in fact experienced a decline in consumption (Figure 7). In just seven years between 2004 and 2011, the gap between the richest 10\% of Malawians and the poorest $40 \%$ increased by almost a third. ${ }^{82}$
IIIIIIIIIIIIIIIIIIIIIIIIIIIIIIIIIIIIIII

BETWEEN 2004

AND 2011, THE

GAP BETWEEN THE

RICHEST 10\% OF

MALAWIANS AND

THE POOREST 40\%

INCREASED BY

ALMOST A THIRD.

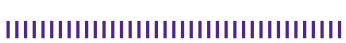


Closing the divide in Malawi

How to reduce inequality and

increase prosperity for all

Figure 6 GDP per capita (constant 2010 US\$)

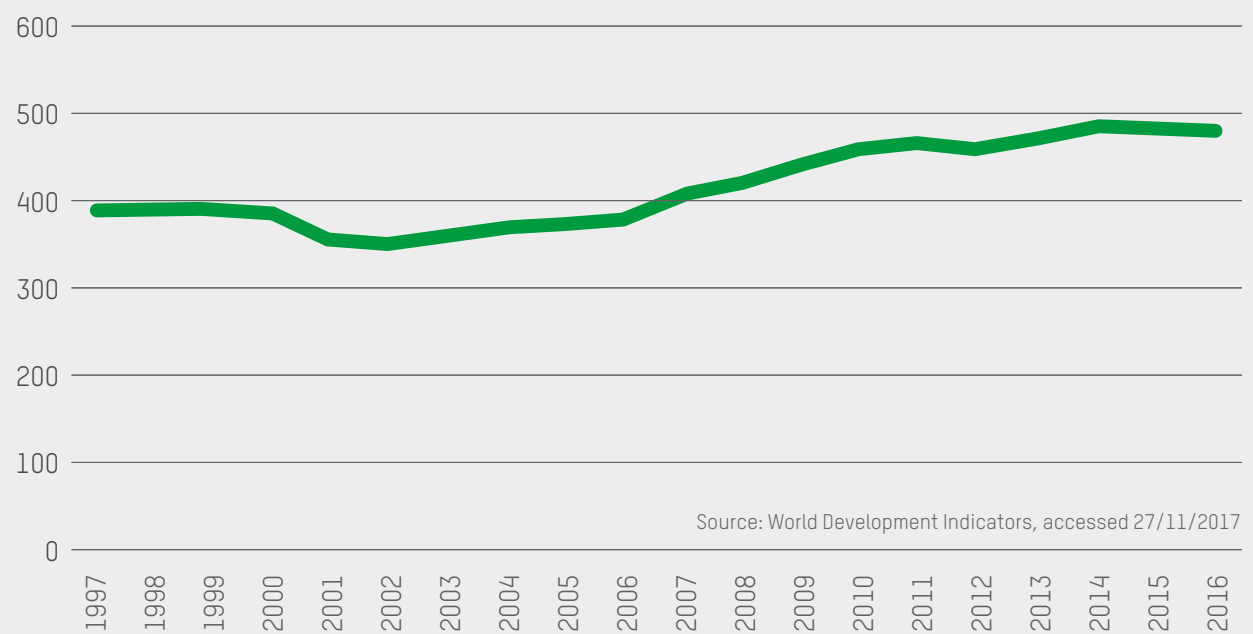

Figure 7 Annual average consumption growth by decile 2004-2010

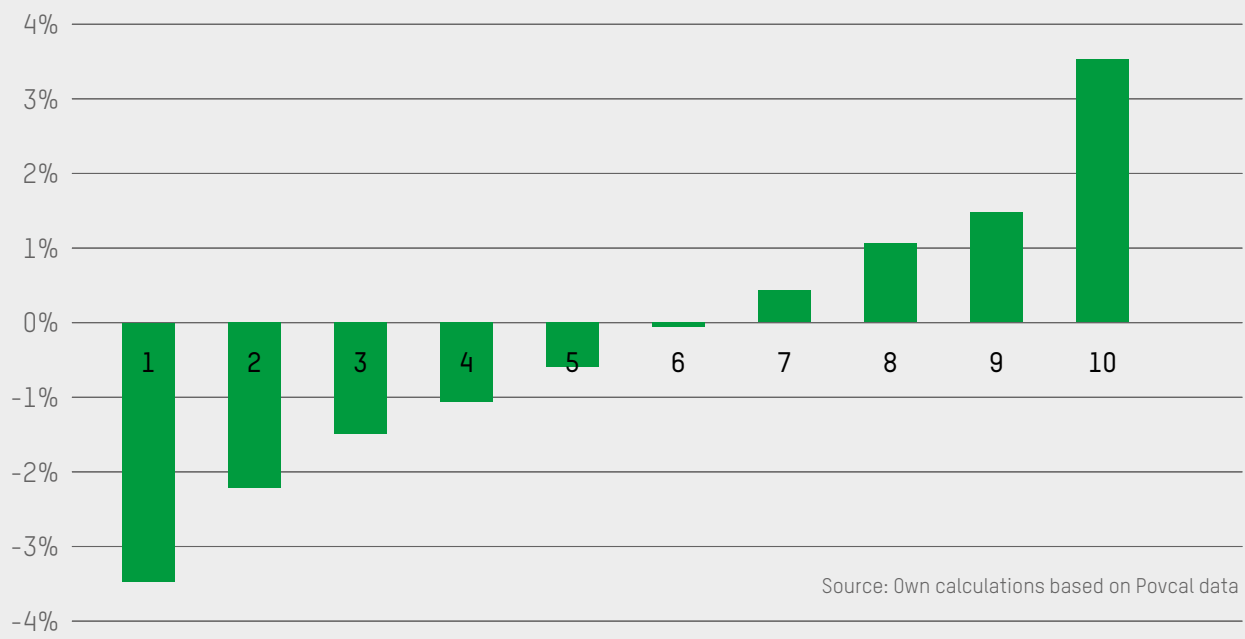


Closing the divide in Malawi

How to reduce inequality and

increase prosperity for all

Against this backdrop, Malawi's economic and political system is leaving the majority of people trapped in poverty, while a small but powerful minority occupy the top end of the inequality divide. Malawi has one of the smallest middle classes in the world, with only $4 \%$ living on $\$ 2-4$ a day and $5 \%$ on $\$ 4-20$ a day in 2010.83

\section{Closing the gap between the rich and the rest}

Ensuring a more prosperous and equal future for all Malawians requires policy making which tackles the drivers of poverty and inequality, as outlined in the following sections. It also demands the setting of clear targets for policy action and criteria for assessing progress. In particular, the Government of Malawi should:
- Develop a clear National Inequality Reduction Plan, including inequality and poverty reduction targets to close the gap between rich and poor in line with the principle of 'leave no one behind' and Sustainable Development Goal (SDG) 10 - 'progressively achieve and sustain income growth of the bottom $40 \%$ of the population at a rate higher than the national average. ${ }^{84}$ These need to be complemented by a target reduction in the Palma ratio (ratio between the income share of the bottom $40 \%$ and the top $10 \%$ of the income distribution), as this would ensure that economic growth is balanced and equitably distributed across the population.
- Develop a robust data collection system to support policy development, target setting and monitoring of progress. The system should ensure adequate disaggregated data collection so that it is able to collect data on the most marginalized groups and support monitoring and achievement of 'Leave no one behind' targets.

\section{TACKLING THE DRIVERS OF INEQUALITY}

Inequality is not only a question of income and wealth distribution. It also concerns inequality of opportunity, such as unequal access to health and education services. Inequality of opportunity fixes a cycle that leads to unequal outcomes. One key driver of economic inequality is power: who makes decisions, and who holds and controls capital and finance. Power imbalance is pervasive in all inequalities, including gender, and at all levels of society. Oxfam's analysis identifies the two foremost structural drivers of inequality in Malawi as the political capture of government and public institutions by the country's minority elite, and the pervasive social norms that underpin extreme gender disparities in all aspects of life.

\section{Political capture and corruption}

A key driver of inequality in most countries is political capture, whereby a minority of often wealthy people have a disproportionate influence over policy making, and rig the rules to work in their favour. ${ }^{85}$ Malawi is no different in having elites use their influence on political decision making to further increase their power or make financial gain. Oxfam regards improvement in the governance of public and political institutions in Malawi as the most critical foundation for reducing inequality and poverty in the country. Oxfam's Dangerous Divide report found in 2015 that the embezzlement of public funds is a significant contributory factor to increasing inequality and poverty in Malawi. ${ }^{86}$ Corruption is one of the most extreme forms of political capture. It is the result of a complete failure of public accountability, and weak governance across political and public institutions. It is a deeply regressive tax on the poor, who pay twice for corruption. Firstly, the bribes they themselves must pay are a far greater proportion of their income than for the richest. Secondly, it is the poorest who lose out the most because of the reduction in public spending as a result of grand corruption and theft.

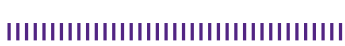

INEQUALITY IS NOT

ONLY A QUESTION

OF INCOME AND

WEALTH. IT

ALSO CONCERNS

INEQUALITY OF

OPPORTUNITY,

SUCH AS UNEQUAL

ACCESS TO HEALTH

AND EDUCATION

SERVICES.

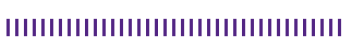


Closing the divide in Malawi

How to reduce inequality and

increase prosperity for all

President Mutharika conceded in 2016 that corruption in Malawi continues to hamper the country's development prospects. ${ }^{87}$ Corruption is also perceived to be worsening. In 2012 , Malawi was ranked 88 out of 174 countries in a major corruption index; in 2016, it fell to 120 th place. ${ }^{88}$ Box 2 gives more detail on how corruption contributes to increasing inequality and poverty in Malawi.
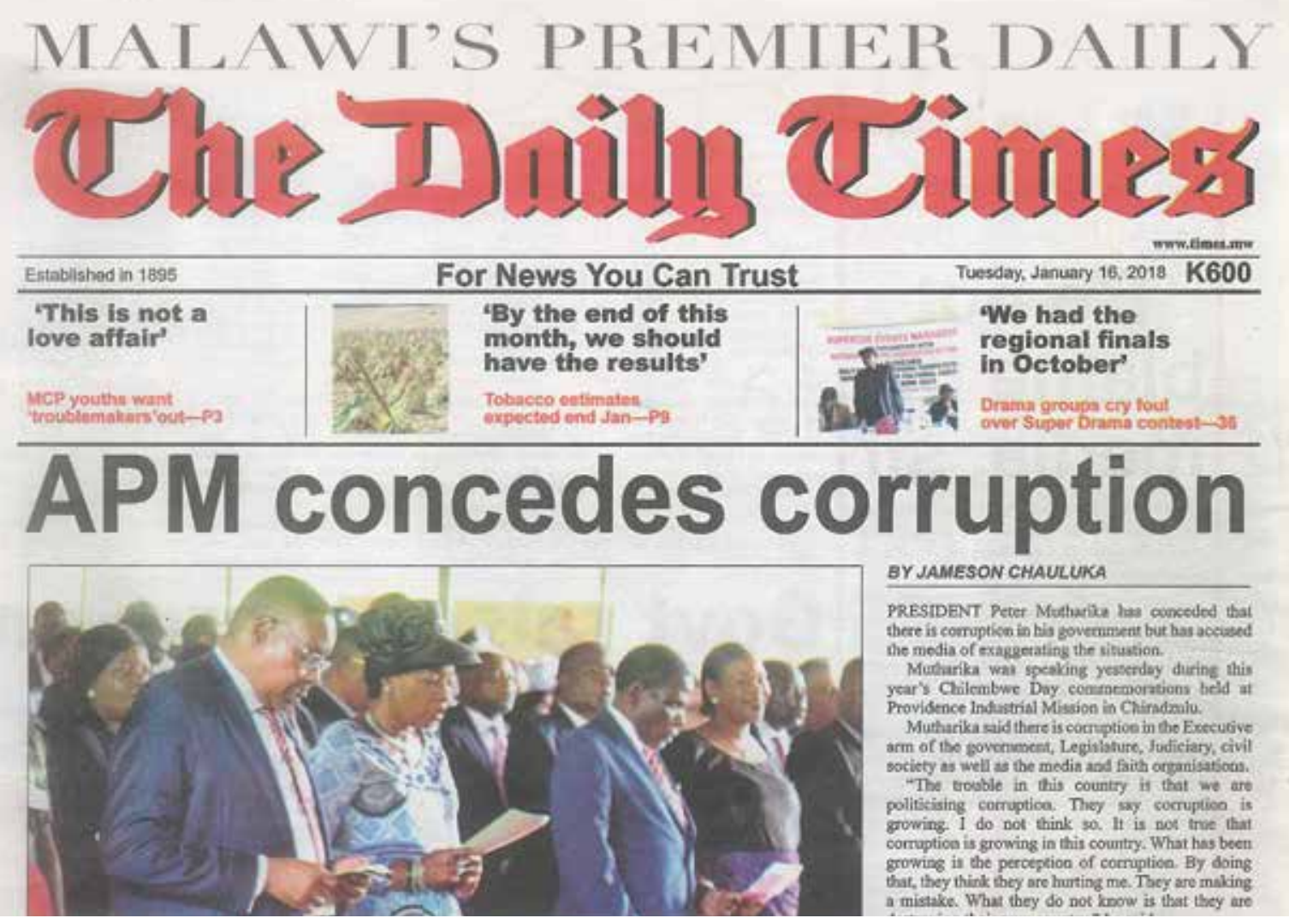

Tuesday, January 16,2018 K600

\begin{tabular}{|c|c|c|c|c|}
\hline $\begin{array}{l}\text { 'This is not a } \\
\text { love affair' }\end{array}$ & - & $\begin{array}{l}\text { "By the end of this } \\
\text { month, we should } \\
\text { have the results' }\end{array}$ & 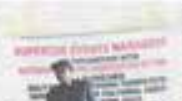 & $\begin{array}{l}\text { We had the } \\
\text { regional finals } \\
\text { In October? }\end{array}$ \\
\hline $\begin{array}{l}\text { MCP youthe want: } \\
\text { troublemaliars'out-Pa }\end{array}$ & $8 \times 2$ & $\begin{array}{l}\text { Tobaceo eetimaten } \\
\text { expected end Jan - P3 }\end{array}$ & & $\begin{array}{l}\text { Drama groupa cry fout } \\
\text { over Steper brama contest-at }\end{array}$ \\
\hline
\end{tabular}

APM concedes corruption

BY JAMESON CHAULUKA

PRESTDENT Peter Mutharita las counceded that there is comptison in his government but has accised. the media of exaggetating the situstion.

Motharika wai speaking yesserday durine this year's Clilembwe Day coninemorztions beld af Providence industrial Mission in Chiradzuiu.

Mutharika said there is concrption in tho Extcufive arm of tho govonment, Leginlature, Jucieiary, civil society as weli ats the media abd faith organisatiota. The trouble in this country is that we are politicising corruptica. They say coctuption is growing 1 do not think 30 . It is not true that corruption is growing in this coumtry. What has been growing in the perception of corruption. By doing that, they think they are hurting me. Tocy are making a mistake. What they do nor know is that they aro

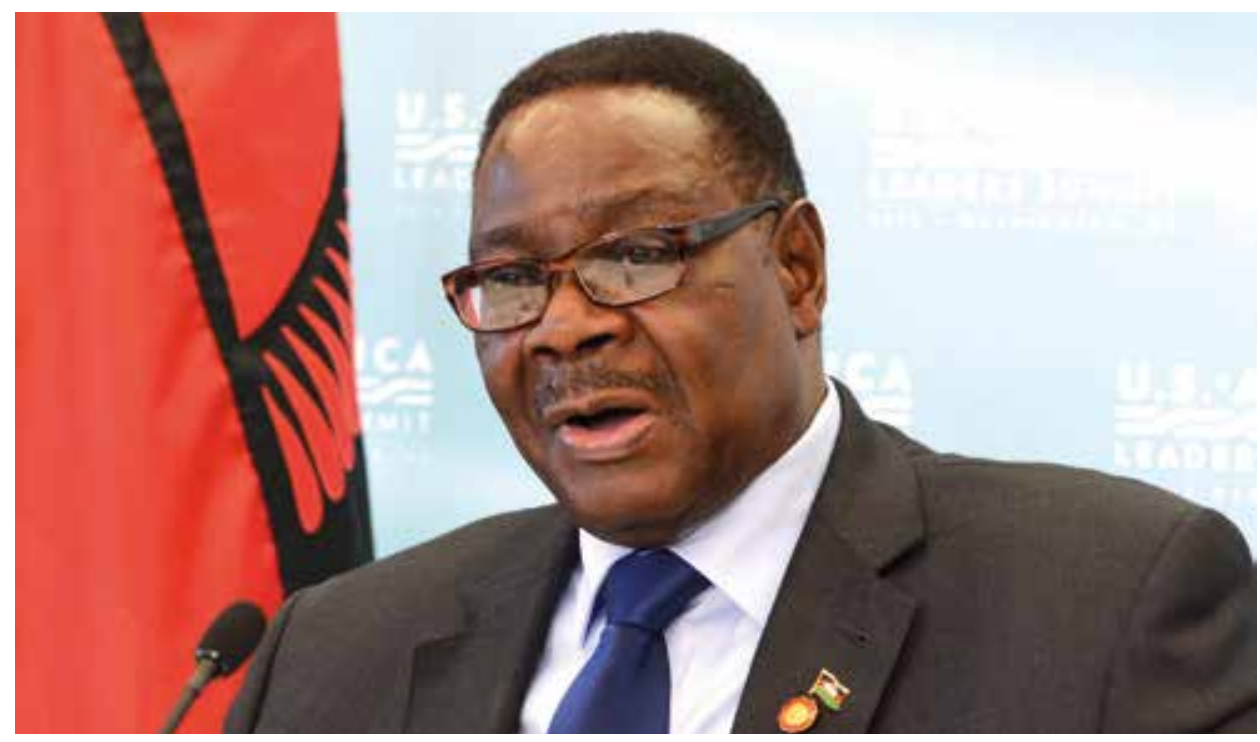

President Peter Mutharika (pictured above at the Chilembwe day commemorations and below left) concedes that there is corruption in the country that is hampering development. Photo: The Daily Times, Malawi 


\section{Closing the divide in Malawi How to reduce inequality and increase prosperity for all}

\section{BOX 2. HOW CORRUPTION IN MALAWI DRIVES POVERTY AND INEQUALITY}

Malawi has suffered a multitude of corruption scandals on a grand scale, characterized by significant theft of public resources by people in positions of power. It is estimated that one-third of Malawi's budget is lost to corruption. ${ }^{89}$ In December 2016, 'Maizegate' saw an alleged MWK 9.4bn (\$13m) go missing in a deal buying maize from Zambia, at a time when almost one in three Malawians urgently needed food aid. ${ }^{90}$ Malawi's most notorious scandal, 'Cashgate', saw an initial theft of MWK $24 \mathrm{bn}(\$ 33 \mathrm{~m})$ of public money, equivalent to almost $40 \%$ of the government's planned spending on education that year. ${ }^{91}$ It is now thought that MWK $236 \mathrm{bn}$ ( $\$ 325 \mathrm{~m}$ ) may be unaccounted for between 2009 and 2014 - almost double the most recent annual health budget. 92

Cashgate has taken a grave toll on ordinary Malawians, especially through its impact on public spending. The almost total suspension of aid to health in the immediate aftermath of Cashgate predicated a health sector crisis, which Malawi's hospitals and clinics are still reeling from. ${ }^{93}$ The poorest suffered the most: first, as a result of the revenues stolen and loss of public finance for public services which the poorest - especially women and girls - are more likely to rely on, and which increases the unpaid care burden on women; second, through the subsequent longer-term withdrawal and/or revised channelling of aid; and finally, through the government's introduction of highly regressive measures to fill the financing gap, such as hospital bypass fees (fees charged when treatment is sought directly at hospital level, circumventing primary healthcare).$^{94}$ With the better-off largely cushioned against the worst impacts, corruption on this scale can only grow Malawi's inequality gap.

Malawi has made efforts to clamp down on corruption. For example, prosecutions following Cashgate have seen multiple convictions, with more proceedings against a number of highprofile suspects underway. ${ }^{95}$ Given the extent of the problem of corruption in Malawi, more needs to be done both in Malawi and at an international level. Developed countries are often complicit in the architecture which sustains corrupt practices. Some investigations into unexplained assets have been hampered where funds are housed in bank accounts outside Malawi, for example. ${ }^{96}$ Alongside playing a vital role improving transparency and accountability in the global financial system and supporting Malawi's asset recovery efforts, international actors must also help to finance the reforms and institutions needed to tackle corruption in Malawi.

A chief reason for a small wealthy elite gaining so much influence over the political process has been the party funding mechanism. ${ }^{97}$ Parliamentary candidates have historically borne the majority of the costs of election campaigns, effectively excluding those without sufficient wealth from standing. This particularly disadvantages women (who comprise just $16.6 \%$ of parliamentarians), as they are less likely to be able to access external finance through male-dominated networks of patronage or through loans. ${ }^{98}$ The new Political Parties Act is therefore a welcome step forward in regulating party funding, but this will not lead to substantive change unless the Act's provisions - including those around transparency of political party finances and regulation of state contributions - are fully implemented, and the new Political Parties Registrar is fully funded and its independence assured. Critically, the provisions outlawing cash hand-outs during elections must also be enforced, and sanctions used whenever any provisions of the new Act are breached. 
Yet beyond such institutional strengthening measures - where national and international actors have historically been very active - it is clear that more must be done. To deliver meaningful implementation and impact in the fight against corruption, approaches must be locally driven, more responsive to existing norms and based on a deeper analysis of why a culture of corruption persists..$^{99}$ Additional research and open debate is vital to understand the powerful incentives that fuel this dynamic, affecting both government and donors. ${ }^{100}$ Subsequent acceptance of responsibility by all parties, and bold and sustained action led from Malawi, will then be needed to change it.

\section{Make government work for all citizens}

Public interest and tackling inequalities and poverty in Malawi should be guiding principles of all national policies and strategies, and donor support. Effective governance that represents the will and fulfils the rights of all the people - rather than the interests of a minority elite - is essential for achieving these principles. This means ensuring that every Malawian is equipped to hold the government and other powerful actors to account against their commitments and responsibilities, and that decision makers will listen, and act, accordingly.

The people of Malawi are demanding public accountability. One recent survey showed that $64 \%$ of Malawians 'strongly agree' or 'agree' that ordinary people can make a difference in the fight against corruption'.101

Oxfam proposes that by taking the following action, political inequality can be reduced and more effective governance and democratic institutions can be built:

- The Executive should demonstrate strong political will in the fight against corruption by tabling the revised Corrupt Practices Act, and providing sufficient funding for relevant anti-corruption bodies (such as the Anti-Corruption Bureau and the National Audit Office). Donors should support the financing of these institutions. Efforts should also be made to strengthen the independence of recruitments to anti-corruption bodies ensuring undue power does not lie with the Executive for hiring/firing decisions - and public financial management reforms.

- The government should fully implement the Access to Information Bill and moreover, ensure that civil society organizations and media genuinely have the access and tools to facilitate public scrutiny of government policy making.

- The government should also fully implement the Assets Declaration Law, which can assist in promoting transparency and accountability of those in political office.

- The government and partners should work to increase the political representation of women, in accordance with the SADC Protocol on Gender and Development commitment to $50 \%$ female political representation, introducing a plan of measures to achieve this target, e.g. through quotas or reserved seats. ${ }^{102}$

- The government must ensure full implementation of the new Political Parties Act, including provisions on equal access to sufficient public campaign finance for political parties, strengthened transparency and regulation of party finances, and outlawing of hand-outs during election campaigns. The independent registrar must be fully funded and empowered to administer the Act, including by applying necessary sanctions. The Act may also need revisiting to strengthen regulation of or exclude foreign donations, limit private donations, and introduce comprehensive, public and timely reporting on political financing in future.
IIIIIIIIIIIIIIIIIIIIIIIIIIIIIIIIIIIIII

PUBLIC INTEREST

AND TACKLING

INEQUALITIES AND

POVERTY IN MALAWI

SHOULD BE GUIDING

PRINCIPLES OF ALL

NATIONAL POLICIES

AND STRATEGIES,

AND DONOR

SUPPORT.

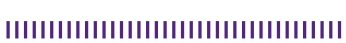

IIIIIIIIIIIIIIIIIIIIIIIIIIIIIIIIIIIIII

THE PEOPLE OF

MALAWI ARE

DEMANDING PUBLIC

ACCOUNTABILITY.

MANY MALAWIANS

BELIEVE THAT

ORDINARY PEOPLE

CAN MAKE A

DIFFERENCE IN

THE FIGHT AGAINST

CORRUPTION.

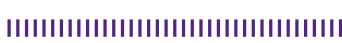


- The government and partners must strengthen parliamentary oversight of the Executive through increased financing for parliamentary committees for example, guarantee a free and open media, and encourage political parties to strengthen preelection manifestos to help build a political system based on policy as opposed to personality or regional loyalties.

- The government and all political parties must also commit to a genuine zerotolerance approach to corruption, and to a long-term project of strengthening Malawi's governance and institutions. All partners must work together and develop joint incentives to encourage success across governance reforms in a cross-party compact. Open debate and analysis of existing norms and incentives for corruption will need to inform this. Civil society, including groups representing women and marginalized groups, should campaign for this in the run-up to the 2019 elections.

International donors have a critical role to play in supporting Malawi to improve its governance. Donors should support effective legal frameworks and institutions to ensure that resources are not misspent, diverted or squandered, with both long-term, sustainable funding and technical assistance. Donors can also play a valuable role in supporting research and national debate to identify appropriate and impactful measures to strengthen governance, incorporating reflections on their own responsibilities and - positive or negative - impact. They must also ensure the quality of their own aid, as is articulated later in this paper.

Critically, donors should also do more to support civil society organizations. This includes providing funding to strengthen their capacity to monitor and hold their government to account, and supporting the government to provide a legal environment within which civil society organizations that monitor government activities can flourish. Particular effort should be made to ensure that women's rights organizations have the space and support to give women a clear, powerful voice. Meaningful systemic change towards gender equality and women's rights can only happen with significant resources and political backing to address women's marginalization in decision-making spaces.

\section{Gender inequality}

Tackling Malawi's deep-seated and widening gender divide must be a priority for the country's government and international institutions. Action is urgently needed across the spectrum of government policy to redress the economic, social, environmental and power inequalities between men and women in Malawi, focusing especially on women who are also in marginalized social groups. Gender inequality shapes and is shaped by societies, culture and economies. Women face a much more restricted set of choices and opportunities in their lives than men, including in their access to healthcare and education, sexual and reproductive health choices, and control over household income and assets. This is in contravention to women's rights. It is also economically and socially damaging. Strong evidence exists showing that more equal participation of women in the economy would drive global economic growth and contribute to women's economic empowerment. ${ }^{103}$ To achieve those social and economic gains, the social and cultural norms that make gender inequality somehow acceptable must be challenged.
IIIIIIIIIIIIIIIIIIIIIIIIIIIIIIIIIIIIIII

INTERNATIONAL

DONORS HAVE A

CRITICAL ROLE TO

PLAY IN SUPPORTING

MALAWI TO IMPROVE

ITS GOVERNANCE.

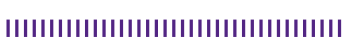

| IIIIIIIIIIIIIIIIIIIIIIIIIIIIIIIIIIIIIIII

HUMAN RIGHTS ARE

WOMEN'S RIGHTS,

AND WOMEN'S

RIGHTS ARE HUMAN

RIGHTS.

HILLARY CLINTON, FORMER US SEANATOR.

IIIIIIIIIIIIIIIIIIIIIIIIIIIIIIIIIIIIIII 
Closing the divide in Malawi

How to reduce inequality and

increase prosperity for all

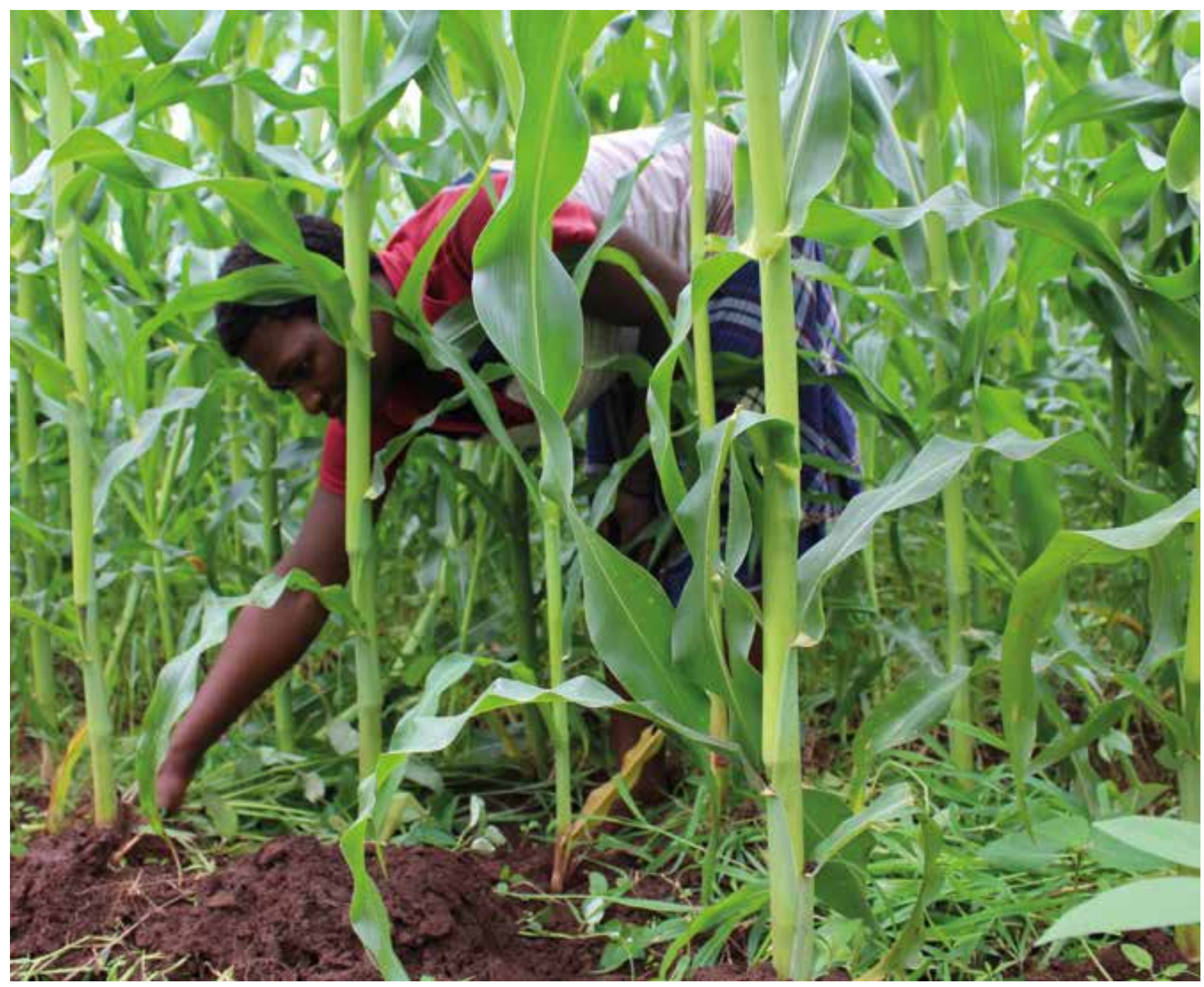

Malawi ranks as one of the world's worst countries for the position of women and girls, coming 145th out of 159 nations in terms of gender inequality, according to the UNDP's Gender Inequality Index. ${ }^{104}$ It is one of a handful of countries in Africa where the gender gap is widening. ${ }^{105}$ Gender inequality and discrimination is estimated to cost Malawi $\$ 100 \mathrm{~m}$ in lost agricultural productivity alone. ${ }^{106}$ While the average amount of time spent on water collection has fallen, ${ }^{107}$ the failure to secure a reduction between 2010 and 2015 in the number of rural households spending more than 30 minutes per day to collect drinking water nevertheless suggests that women's priorities continue to be severely undervalued in Malawi's economic, social and environmental development. ${ }^{108}$ Box 3 below highlights how pervasive gender inequality is in Malawi. What these facts do not sufficiently convey is how gender inequality is exacerbated where gender intersects with other dimensions such as age, class, education, sexuality and disability. $\triangle$

Women's economic

participation drives economic growth. Photo: Daud Kayisi/ Oxfam in Malawi

IIIIIIIIIIIIIIIIIIIIIIIIIIIIIIIIIIIIII

OWNERSHIP OF LAND

IN PARTICULAR HAS

IMPLICATIONS FOR

WOMEN'S ABILITY TO

ACCESS CREDIT OR

OTHER FINANCIAL

SERVICES.

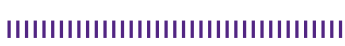


Closing the divide in Malawi

How to reduce inequality and

increase prosperity for all

\section{BOX 3. A SNAPSHOT OF GENDER INEQUALITY AND DISCRIMINATION IN MALAWI}

The percentage of women who have experienced physical violence since the age of 15 has increased from $28 \%$ in 2004 to $34 \%$ in $2015-16$, while $42 \%$ of married women have experienced spousal violence. ${ }^{109}$

Employed women face higher rates of physical violence, including sexual violence, than those who are unemployed. 110

Almost half of all girls in Malawi can still expect to be married before they are 18, while up to $30 \%$ of maternal deaths occur in teenage pregnancy. ${ }^{111}$

Barriers to women's economic empowerment remain high: only $3 \%$ of women are registered owners of commercial land for example, yet they represent $70 \%$ of the workforce. ${ }^{112}$

Currently, female representation at parliament level is at $16.6 \%$; at local government level is at $11 \%$ and at cabinet level is at $20 \%$.

$93 \%$ of women's labour in Malawi is unpaid, ${ }^{113}$ while a quarter of married women report that their husbands decide how to spend their earnings. ${ }^{114}$

The statistics in Box 3 highlight not just the size of the challenge, but also the failure to make any transformative change over the last decade in tackling the violation of the rights of Malawi's nine million women and girls.

There has, however, been some progress. The constitution has recently been amended to outlaw marriage below the age of 18,115 and Malawi is recognized for having in place a robust legal and policy framework in some areas of women's rights. Malawi's record in achieving gender parity in primary education has shown that, despite the significant remaining challenges for girls and women in education, rapid progress is possible. ${ }^{116}$ Universal access to good quality and free public services, such as healthcare and education, has been shown to reduce inequalities - including gender inequality - so this is of particular importance. ${ }^{117}$ Free public health services help to shift the financial and other burdens le.g. unpaid and unequal care loads) that come with ill health back on to the much broader shoulders of society as a whole, helping to liberate women and girls, and to level gender disparities.

\section{Put gender equality and women's economic empowerment front and centre of} policy making

However, far more progress is needed to close Malawi's gender divide, not only in access to public services but also in the quality of women's participation in productive sectors (like agriculture and mining), access to decent and equally paid work, and opportunities to progress and manage businesses. Fiscal systems need to be sensitive to gender to ensure fairness and that tax and spend policies respond sufficiently to women's needs and create incentives and revenues for women and girls to reduce and redistribute the heavy unpaid care loads they shoulder. As already discussed, there must also be more gender equality in political representation.

Critically, Malawi must address the social norms that are still undermining the more progressive gender and women's rights policies, preventing progress, and even contributing to rising cases of violence against women and girls. The country needs to have a strong focus on women at the intersection of social exclusion. This needs a cross-party and a

|I|IIIIIIIIIIIIIIIIIIIIIIIIIIIIIIII

FISCAL SYSTEMS

NEED TO BE

SENSITIVE TO

GENDER TO ENSURE

FAIRNESS AND THAT

TAX AND SPEND

POLICIES RESPOND

SUFFICIENTLY TO

WOMEN'S NEEDS.

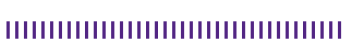




\section{Closing the divide in Malawi \\ How to reduce inequality and \\ increase prosperity for all}

cross-government coordinated approach, guided by a national plan that is championed by all ministries and agencies, and is backed up by revenue and spending plans under the Ministry of Finance that are demonstrably responsive to this agenda.

This national plan should be designed to articulate how Malawi is going to reach the targets set out in Agenda 2030's SDG 5 - 'Achieve gender equality and empower all women and girls.'

Specific policy actions that the Government of Malawi can include in a plan to reach SDG5 can be found in each section of this paper. However, there are some structural drivers of gender inequality and women's disempowerment that, if tackled effectively, could be transformative:

- Increase women's voice, representation and independence: Within relationships, at the household, community and policy levels, the majority of women in Malawi - and particularly rural women - do not have a proper voice or a full say in decisions that affect them and their families. ${ }^{118}$ Supporting a strong, vibrant and open women's movement and space for women to engage fully in decision making requires sufficient funding and an enabling political environment for independent women's organizations to operate safely and effectively. The influence of women's organizations in tackling gender inequality surpasses that of having more women in the legislature, progressive political parties in power or improvements in national wealth. ${ }^{119}$

- Increase women's ownership and control over assets: Individual ownership of assets such as property, land, mobile phones and bank accounts is lower among women than for men. ${ }^{120}$ Initiatives, including a stronger legal framework, are needed that give women, particularly poorer or otherwise excluded women, access to credit, control over their earnings and access to sufficient land, which are key determinants for accelerating women's economic inclusion. ${ }^{121}$ Ownership of land in particular has implications for women's ability to access credit or other financial services. Fear of land loss has impacts on farm productivity, as well as limiting resilience and chances of improving livelihoods. Recent land reforms recognize customary tenure and rights, and provide opportunities for poorer women, but also present significant risks that women could lose their land if the new laws are abused. Serious attention will need to be given to ensuring the reforms are operationalized in a gender-sensitive way. ${ }^{122}$

- Take action to end violence against women and girls: Important legal changes have been secured to address domestic violence in Malawi and also make child marriage illegal. Yet gender-based violence remains so entrenched socially that being beaten by a husband is deemed in some circumstances to be acceptable by $16 \%$ of women, attitudes that appear not to have shifted since 2010. ${ }^{123}$ Urgent action is required to demonstrate that proper implementation and enforcement of government policies is a priority, to reassure women and deter perpetrators. This is one of the most important ways to create a normative shift in Malawi towards a culture where violence against women and girls is never tolerated. 
Closing the divide in Malawi

How to reduce inequality and

increase prosperity for all

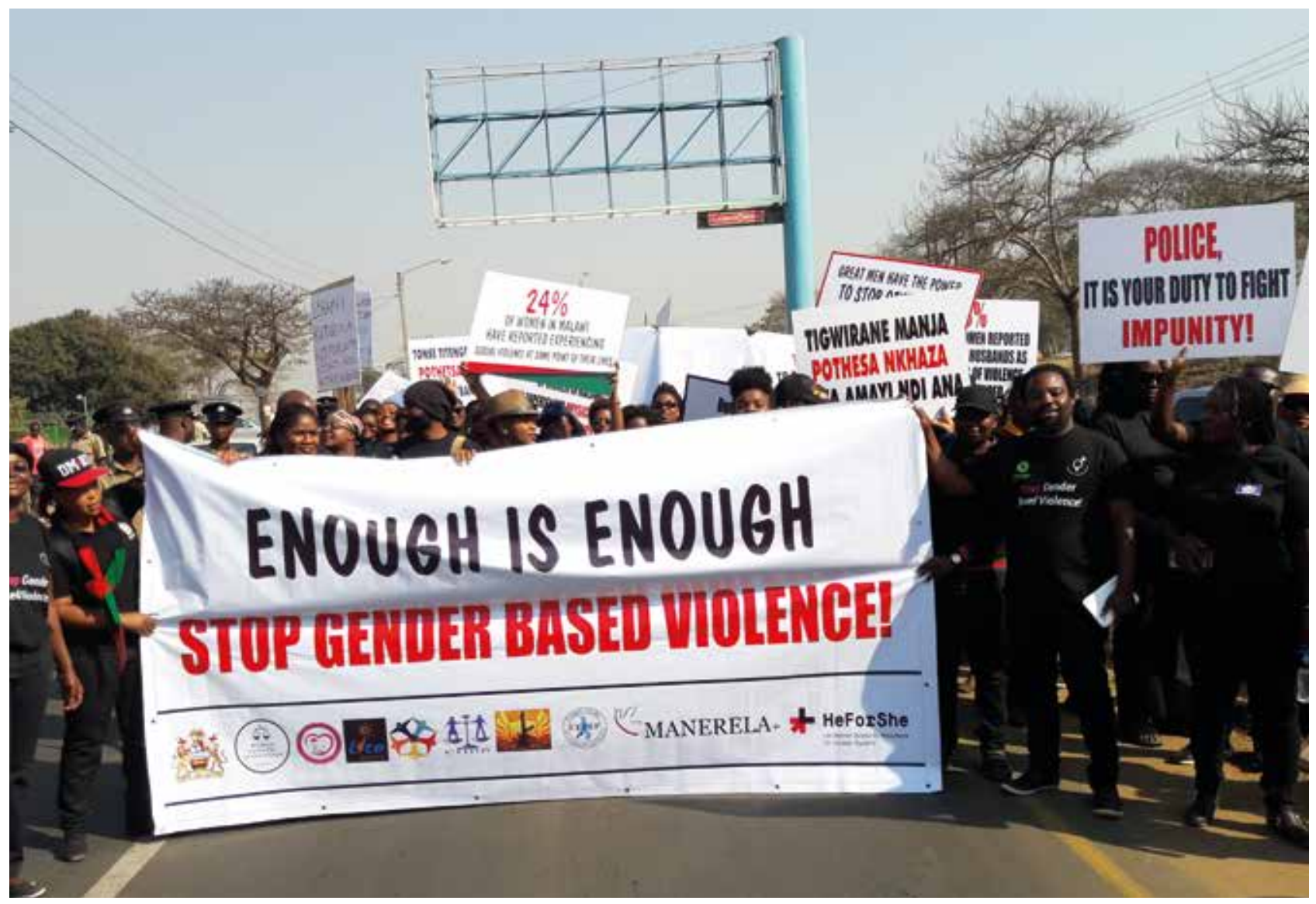

- Deliver a coordinated and concerted response to the unpaid care work falling on women and girls: Women in Malawi undertake considerably more unpaid care work than men, particularly younger adult women. ${ }^{124} \mathrm{Unpaid}$ care work has important impacts across a variety of issues including levels of violence against women, and women's health and mobility. It also has implications in terms of women's participation in productive work, public and political participation, decision-making power, and control over assets at the household level. Moreover, unpaid care work prevents women from pursuing personal interests as well as fully enjoying basic needs/rights such as sleeping or personal care, and has a direct negative impact on their wellbeing. In line with global recommendations from a UN High-Level Panel, 125 the Government of Malawi should evaluate and ensure a coordinated response to this issue, including investing in care services for all Malawians, and investing in time- and labour-saving devices and basic infrastructure (water, health, education and safe transport) that could help to reduce the burden of care work and distribute it more equally within households and between households and the state.

\section{$\Delta$}

A solidarity march against gender based violence organised by Oxfam, civil society organisations and human rights defenders held on 14 September 2017 in Lilongwe, central Malawi. 


\title{
Closing the divide in Malawi \\ How to reduce inequality and \\ increase prosperity for all
}

\section{MAKE THE ECONOMY WORK FOR EVERYONE}

Malawi must start managing its economy to deliver growth which is transformative for all people. This means ensuring greater government and public institution accountability, regulating business to work in the interests of producers and workers, building resilience and environmental sustainability, promoting the empowerment of women, and working towards improved domestic resource mobilization to invest in good quality public services for all. The Malawi Growth and Development Strategy III (2017-2022) (henceforth MGDS III) is looking to five priority areas: (i) Agriculture, Water Development and Climate Change Management; (ii) Education and Skills Development; (iii) Transport and ICT Infrastructure; (iv) Energy, Industry and Tourism Development; and (v) Health and Population. ${ }^{126}$ These are the right priorities to tackle Malawi's underlying development challenges of reducing poverty and various forms of inequality, boosting agricultural performance and achieving structural transformation. However, across each of these areas, policies need to be designed and implemented to work for all Malawians.

\begin{abstract}
AGRICULTURE
Agriculture constitutes the backbone of the Malawian economy, and agricultural performance has more significant implications than any other sector for economic growth, and for reducing social and economic inequalities and poverty - especially in rural areas. Other developing countries that have managed to grow in a way that reduces inequality have had strong growth in the smallholder agriculture sector. ${ }^{127}$ Most of the population lives in rural areas (84\% in 2015) and is employed in agriculture (64.1\% in 2013), ${ }^{128}$ most of which is subsistence farming. More than $70 \%$ of agricultural GDP comes from smallholders,; ${ }^{129}$ and women, especially those aged 45-54, represent the largest share of subsistence farmers. ${ }^{130}$ Household experience of food insecurity is substantially higher in rural than in urban areas (respectively $66 \%$ and $42 \%$ ). ${ }^{131}$

While the sector has experienced growth over recent years, that growth has been volatile. According to International Food Policy Research Institute (IFPRI) data, agricultural output grew by $5.86 \%$ between 2008 and 2013, but Figure 8 shows the volatility of that rising growth. Performance has been particularly hit by extreme weather conditions since 2014 . Maize production during the $2015 / 16$ growing season declined by an estimated $12.4 \%$ relative to production in 2014/15. ${ }^{132}$ Over the past five years, this - along with large rises in input prices - has translated into half of the country's farmers suffering from agriculturalrelated shocks, and increased food insecurity in many parts of the country. ${ }^{133}$

Malawi's 2.7 million smallholder farmers are predominantly engaged in maize production, and in some cases in production of burley tobacco as a cash crop. ${ }^{134}$ According to the fourth Integrated Household Survey, $76 \%$ of rainy season plots are cultivated with maize. ${ }^{135}$ As well as managing their own plots, smallholder farmers are also involved in agricultural waged labour, which is generally very low-paid and casual. ${ }^{136}$ Poorer and women-headed households are most dependent on agriculture for income, and generally have smaller land holdings than men. ${ }^{137}$
\end{abstract}


Closing the divide in Malawi

How to reduce inequality and

increase prosperity for all

Figure 8 GDP and agriculture growth patterns (1997-2016)

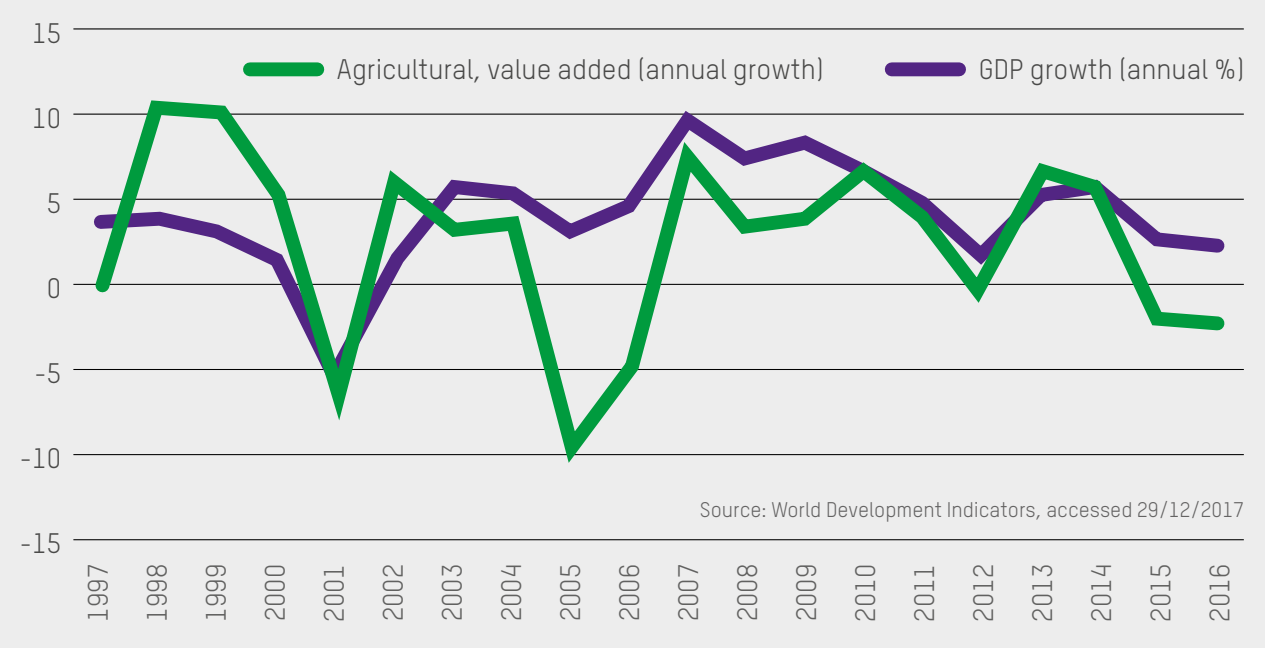

A lack of basic irrigation infrastructure and lack of access to capital to purchase fuel for pumps means that most maize is almost entirely rain-fed, and often grown on tiny plots and in poor soils. ${ }^{138}$ Farmers are thus highly susceptible to weather shocks, and climate change is expected to continue impacting heavily on farmers' ability to produce and earn a living from maize unless more low-cost water storage and irrigation systems can be put in place. This needs to be part of a broader shift ${ }^{139}$ towards conservation agriculture and agroforestry that can restore soil fertility and withstand periods of drought and of heavy rainfall. This is all the more pressing given increasing population density, which is squeezing plot sizes and limiting any growth in the use of fallowing. ${ }^{140}$ Farmers also have limited access to inputs like seeds and tools, and advice, with just $14 \%$ of female-headed households leven less for those with smaller land holdings) attending training events. ${ }^{141}$
IIIIIIIIIIIIIIIIIIIIIIIIIIIIIIIIIIIII

FARMERS ARE

HIGHLY SUSCEPTIBLE

TO WEATHER

SHOCKS, AND

CLIMATE CHANGE

IS EXPECTED TO

CONTINUE IMPACTING

HEAVILY ON

FARMERS' ABILITY

TO PRODUCE AND

EARN A LIVING.

IIIIIIIIIIIIIIIIIIIIIIIIIIIIIIIIIIIIIII 


\section{Closing the divide in Malawi How to reduce inequality and \\ increase prosperity for all}

Malawi's agriculture sector is characterized by a dual structure, so that the smallholder farming sector operates alongside, and provides labour to, a large farming estates sector, which produces tobacco, tea, sugar and coffee - almost entirely for export. Until recently, this dual structure has been reinforced by a range of policy interventions, including subsidies and incentives, an abundance of low-paid, casual wage labour (ganyu) and, throughout the 1990s, transfers of land from the customary tenure sector to commercial estates. This has resulted in high land insecurity for smallholder farmers and frequent landrelated disputes, compromising their capacity and confidence to invest in higher-value crops or in soil conservation measures. ${ }^{142}$

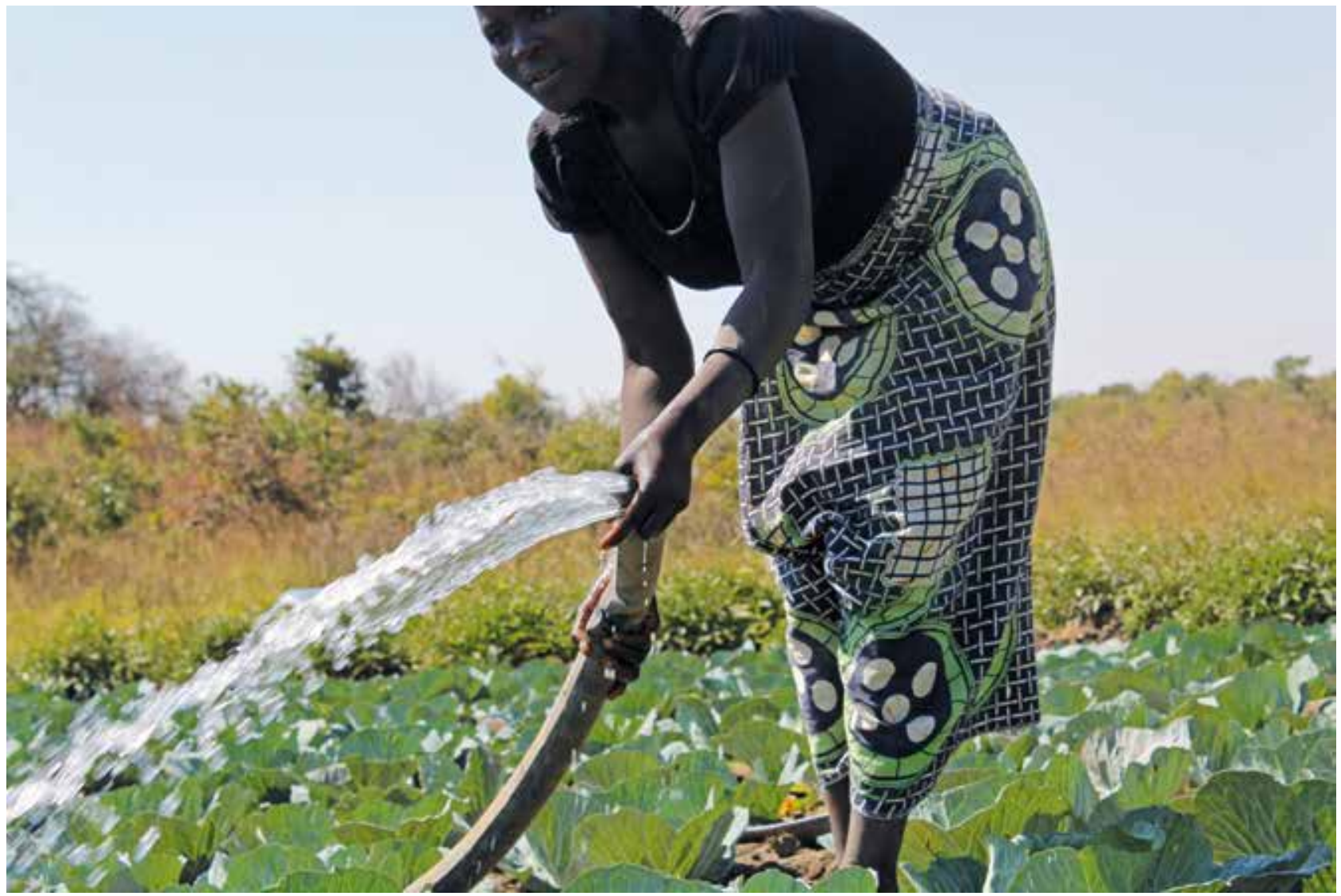

Throughout the 1990s and the early 2000s, Malawi's agricultural strategy was largely driven by the precepts of the Washington Consensus, and therefore oriented towards rapid liberalization and the removal of state involvement. ${ }^{143}$ This approach failed to create the conditions for equitable growth and structural transformation, and left farmers even more vulnerable to poverty, with consequences which are still felt today. Since 2006, the Government of Malawi has pursued a growth strategy based on increasing the volume of agricultural exports, driven by the country's competitive advantage in the production of tobacco and cotton. However, these policies have also failed to properly meet the needs of smallholder farmers.

Boxes 4 and 5 illustrate two of the main government agriculture initiatives. Both have achieved positive results, particularly in their early years of roll-out, but now require a redesign to ensure they prioritize the needs of small-scale food producers, where the major gains in productivity, sustainable intensification, poverty reduction and resilience can be achieved.
$\Delta$

Proper irrigation can improve food security for smallholder farmers as well as health and social wellbeing for communities. Photo: Watipaso Kaliwo/Oxfam in Malawi 
Closing the divide in Malawi

How to reduce inequality and

increase prosperity for all

\section{BOX 4. AGRICULTURAL DEVELOPMENT AND MARKETING CORPORATION (ADMARC)}

ADMARC is a parastatal organization created in 1971 with the mandate to market agricultural produce and inputs, promote smallholder agriculture through marketing activities and investments in agro-industry enterprises, and ensure food security by marketing and distributing maize in remote areas. Attempts to privatize the organization, pushed by donors including the World Bank, were met with strong opposition from civil society. The World Bank's own impact assessment showed that ADMARC was vital to the incomes of the poorest, especially in rural areas. ${ }^{144}$

Today, while ADMARC's mandate remains the same, its ability to serve the poorest farmers has been systematically undermined. For example, in early 2016, the media reported critical shortages of maize in ADMARC markets in the country. An Oxfamled rapid assessment found that only six out of 20 markets that ADMARC visited in five districts were selling maize on the day of the visit. Of these six markets, only two were in the hard-to-reach areas. In all six, the stocks lasted just a day, with many people returning home without having been able to buy any maize. The lack of maize had many negative impacts on vulnerable Malawians who had faced soaring maize prices, while losing precious time searching for maize, with many experiencing violence in the process. ${ }^{145}$

Inefficiencies which compromise ADMARC's performance include inadequate funding, which in the past had been disbursed at the wrong time, after the marketing season; non-transparent behaviour of ADMARC staff; and political manipulation of ADMARC's administration.

However, it is encouraging that during the 2016/17 flooding and drought and in response to the ensuing food crisis, ADMARC set a maize market intervention price in line with market forces, which ensured stable prices and subsequently a deceleration in the rate of inflation. ${ }^{146}$ This shows that ADMARC continues to have an important role to play in smoothing maize prices to keep them steady throughout the year, and ensure that there is adequate supply of affordable maize throughout the country.

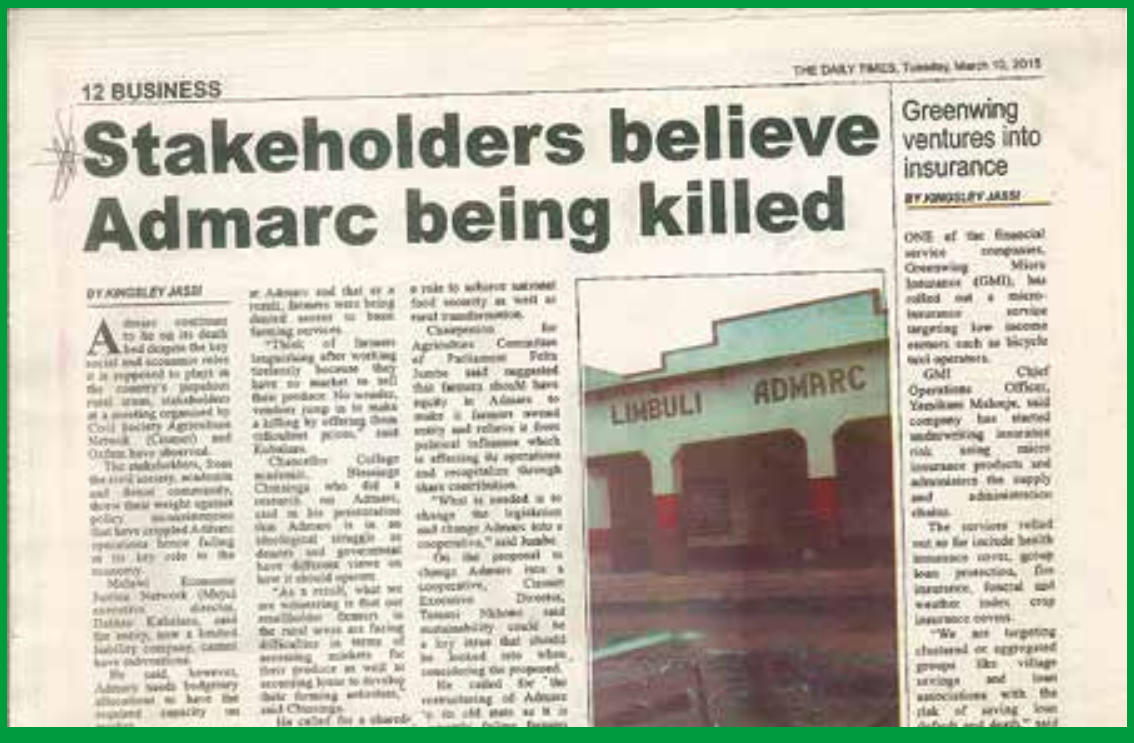

ADMARC, mandated to market agricultural produce and inputs, plays a vital role in the incomes of the poorest, but has experienced inefficiencies that have compromised its performance Photo: Watipaso Kaliwo/Oxfam in Malawi 
Rural markets in Malawi are scarce and where they exist, are inefficient. One of the main reasons for this is that the government and businesses have not adopted policies and practices that guarantee farmers access to natural resources, technology and marketrelated infrastructure, or ensured sufficient public investment in smallholder production.

Addressing this requires public investment in and infrastructure to develop market linkages across rural areas. Private sector investment can play a vital role in delivering inclusive economic growth, environmental sustainability and poverty reduction if it adheres to some key principles, such as focusing on local food markets, working with producer organizations including women's organizations, and respecting and strengthening the rights of smallscale producers, workers and communities.

According to Malawi 2016 National Agriculture Policy, ADMARC will be reformed to improve farmers' access to markets through establishing terms of trade with farmers using a transparent, rules-based approach to market operations. To improve its market efficiency performance, ADMARC's commercial and social functions will be separated. These reforms go in the right direction; however, additional actions are needed to ensure that ADMARC's governance is transparent and accountable, and that it works for the poorest farmers. Reforms should also involve smallholder farmers - including representative voices from women smallholders - contributing to the organization's future mandate and governance. The separation of ADMARC's social and commercial functions is especially critical, and can contribute to pro-poor agricultural growth only if profits from commercial activities are fully ploughed back into public investment in agriculture, with at least half of these investments specifically aimed at integrated and climate-sensitive agricultural development for the poorest farmers.

One of the most important government-led programmes in agriculture has been the Farm Input Subsidy Programme (FISP). Initially lauded as a success, in more recent years FISP has faced serious criticism, due to its raising of costs coupled with the capture of benefits by those farmers that have less or no need for subsidies (see Box 5). Donors, especially the World Bank and the IMF, have asked for substantial FISP reforms. As a consequence, there has been a significant reduction in budget allocation, from $3 \%$ of GDP in 2012/13 (benefiting 1,500,000 farmers) to $0.8 \%$ (benefiting 900,000 farmers) in 2016/17. In addition, the supply of inputs was opened to private suppliers via a fixed-value coupon model, such that the great majority of fertilizer procurement and seed distribution is now managed by the private sector. As a result, in 2016/17 fertilizer inputs were delivered in a timely fashion and for the first time, the FISP was completed within the stipulated budget. ${ }^{147}$ However, delays in the selection of beneficiaries persisted.

Alarmingly, these reforms are likely to have negative effects for the poorest farmers. An IMF study simulated the combined impact of a reduction of the subsidized rate of the maize fertilizer from $100 \%$ to $80 \%$, and of a reduction of the procurement costs by $25 \%$. The IMF study found that while this would improve efficiency and output, it would also increase inequality by reducing the income of small and poor farmers. ${ }^{148}$ The study suggests the introduction of a cash transfer programme to compensate for the negative impact of FISP reforms on the rural poor.

However, cash transfers are not an adequate substitute for agricultural subsidies because they have very different objectives. Cash transfers are a tool for social protection, which is meant to help households stabilize consumption in the face of shocks, but are insufficient on their own to raise household productivity and lift smallholder farmers out of poverty. Further, it is well documented that targeted transfers often fail to reach the intended beneficiaries and end up favouring the better off farmers. ${ }^{149}$ Subsidies, on the other hand,
IIIIIIIIIIIIIIIIIIIIIIIIIIIIIIIIIIIII

RURAL MARKETS

IN MALAWI ARE

SCARCE AND WHERE

THEY EXIST, ARE

INEFFICIENT.

IIIIIIIIIIIIIIIIIIIIIIIIIIIIIIIIIIIII

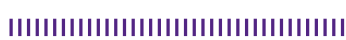

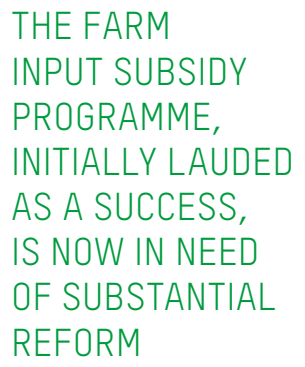

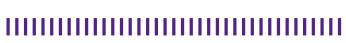


in conjunction with extension support and research, are meant to help farmers in their productive activities. They are especially critical for marginal farmers who have virtually no resources to access the range of inputs at commercial prices. It is therefore worrying that the percentage share of rural households receiving any Farm Input Subsidy Programme Voucher dropped from $60 \%$ in 2010 , to $44 \%$ in 2013, and $36 \%$ in $2016 .{ }^{150}$ The involvement of the private sector is not in itself a guarantee of more equal and more efficient outcomes, as demonstrated by the involvement of multinational companies in the procurement and marketing of seeds (see Box 5).

\section{BOX 5. THE FARM INPUT SUBSIDY PROGRAMME (FISP)}

The FISP was launched in 2005-6 with the aim of promoting food security and selfsufficiency by increasing food production, and in particular maize production, among smallholder farmers. It offers subsidized fertilizers and other inputs to farmers through a coupon system. Over the years, the FISP has consistently accounted for more than half of the total value of public expenditure on agriculture in Malawi. Research assessing the impact of the programme in the period 2005-2012 found a range of positive effects, especially on food production and household income. During this period, the agricultural sector grew rapidly and the country enjoyed substantial maize surplus over and above its annual food requirements. ${ }^{151}$ The programme was found to increase recipient farmers' maize production as a result of increased fertilizer use ${ }^{152,153}$ and also to be associated with rising incomes, falls in stunting and in the prevalence of underweight children. ${ }^{154}$

However, the programme has also received strong criticism, including from donors, for the following reasons:

- Poor targeting: in 2013, only around one-third of rural households in the bottom quintile obtained subsidized inorganic fertilizer, compared to half of those in the top two quintiles, while households headed by older males were treated more favourably than those headed by young females. ${ }^{155}$ In recent years, it has also become common for smaller farmers to exchange their vouchers for cash with larger farmers who are in a better position to make use of seeds and fertilizers.

- Used as an instrument of patronage: particularly by the agro-dealer sector. ADMARC and the Smallholder Farmers Fertilizer Revolving Fund of Malawi (SFFRFM) monopolize the distribution of fertilizers, while private companies are involved in their procurement and transportation to state-run distribution centres. Procurement and marketing of seeds involves multinational seed companies, which tend to operate through agro-dealers: up to $65 \%$ of seed for the $2010 / 11$ FISP was channelled through agro-dealers. ${ }^{156}$ Because only seed companies can redeem vouchers from the government, agro-dealers can only participate in FISP if they have contracts with the government. This means that de facto the entire sector is monopolized by multinational seed companies. ${ }^{157}$ Agro-dealers have little incentive to serve the poorest and most marginalized farmers in remote areas nor to promote local seed varieties, and instead prefer to operate in market hotspots.
|IIIIIIIIIIIIIIIIIIIIIIIIIIIIIIIIIIII

OVER THE YEARS, THE FARM INPUT SUBSIDY SYSTEM HAS CONSISTENTLY ACCOUNTED FOR MORE THAN HALF OF THE TOTAL VALUE OF PUBLIC EXPENDITURE ON AGRICULTURE IN MALAWI.

IIIIIIIIIIIIIIIIIIIIIIIIIIIIIIIIIIIIII 
Achieving robust agricultural growth that benefits all

There is a clear case for a massive, government-led investment, supported by donors, in smallholder farming and supporting infrastructure that works for women and men in a context of volatile weather patterns. Millions of smallholder farmers support themselves and produce for others without the access to markets, land, finance, infrastructure and technologies enjoyed by large estate farms. Addressing this gaping inequity offers a crucial opportunity to address the challenges of sustainable production, resilience and poverty reduction. Closing the gap in productivity between men and women farmers alone is estimated by the World Bank and others to be worth an additional $\$ 100 \mathrm{~m}$ per year or $7.3 \%$ of annual crop output in Malawi. It could lift 238,000 people out of poverty and a further 80,000 out of malnourishment, per year. ${ }^{158}$

It will be critical to facilitate the development of the private sector. Malawi's private sector suffers from a 'missing middle'. It is composed of a small group of large firms, mostly found in agro-processing, trading and retail. At the other end of the spectrum there is a vast number of micro and small enterprises, usually operating in the informal sector. ${ }^{159}$ Enabling growth of mid-size firms will require addressing the specific constraints they face, and redirecting and redistributing state support away from large firms to small and medium ones, including small rural and informal enterprises. Critical interventions include investment in services, infrastructure and technologies that reach women in the most deprived communities and groups, and the most remote areas of the country, and that are demonstrably improving climate resilience. This will also be in view of supporting the expansion of the rural nonfarm sector and with it economic diversification and job creation.

Both the 2016 Malawi National Agricultural Policy and upcoming MGDS III acknowledge these critical issues. In particular, the draft MGDS III sets out a plan to achieve increased agriculture market development, agro-processing and value addition. However, to be effective both policy strategies would need stronger and clearer provisions aimed at overcoming the disparities that exist between smallholder farmers and large estates, concentrating on rebalancing the policy environment in favour of small-scale actors and on closing the gap between women and men farmers.

More specifically, the following steps should be taken:

Put greater emphasis on the realities and needs of small and marginal farmers: This would help identify realistic pathways for creating employment opportunities for the poor and relatively landless, and diversify the country's rural farm and non-farm economy. To this end, the policy needs to be accompanied by more detailed plans on the development of climate-resilient and environmentally sustainable crops and the management of strategic value chains like legumes and horticulture, where opportunities for small farmers can be developed further.

Increase public investment: ${ }^{160}$ The government and donors must increase investment in the productivity, resilience and sustainability of small-scale food producers. This includes substantial investment in rural water, electricity and care infrastructure, and ensuring that land reforms lead to improved land tenure and access for women farmers. In the context of Malawi's vulnerable agriculture, state-led interventions and investment remain critical for increasing productivity of small and marginal farmers as well as for creating the conditions for private sector development.

ADMARC and the FISP: Subsidies for inputs and government support to maize provision and purchasing remain indispensable in Malawi. The role of state intervention should be to compensate for market failure, and to 'crowd in' the private sector by creating markets
IIIIIIIIIIIIIIIIIIIIIIIIIIIIIIIIIIIIIII

THERE IS A

CLEAR CASE

FOR A MASSIVE,

GOVERNMENT-

LED INVESTMENT,

SUPPORTED

BY DONORS, IN

SMALLHOLDER

FARMING AND

SUPPORTING

INFRASTRUCTURE.

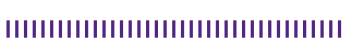

IIIIIIIIIIIIIIIIIIIIIIIIIIIIIIIIIIIIII

THE GOVERNMENT

AND DONORS

MUST INCREASE

INVESTMENT IN

THE PRODUCTIVITY,

RESILIENCE AND

SUSTAINABILITY OF

SMALL-SCALE FOOD

PRODUCERS.

IIIIIIIIIIIIIIIIIIIIIIIIIIIIIIIIIIIIIII 
where they currently barely exist. The State's role is fundamental to boost the size of the agriculture sector and promote private sector investment. To this end, it should focus on creating a reliable and efficient framework for regulating agricultural markets and subsidizing local varieties and inputs, ensuring sustained access to input and output for smallholder farmers, particularly women farmers in very remote areas. Reform of these two programmes should be coordinated with and complemented by adequate investment in social protection, and should ensure that women and men smallholders have a representative stake in their governance.

Create an enabling environment for private sector development and encourage private sector investment: This will mean creating capabilities and opportunities for small and medium firms, for example through the provision of targeted and tailored business development services, including subsidized services for the poorest entrepreneurs. ${ }^{161}$ Key areas of public interventions include investment in infrastructure, especially in view of providing a reliable source of water and electricity, improving access to finance, and reducing corruption faced by firms in dealing with bureaucracy. It will also be necessary to encourage investment that is regulated and adheres to key principles such as focusing on local food markets, working with mixed and women-only producer organizations, and respecting the rights of smallscale producers, workers and communities. To avoid the mistakes of the past, adequate incentives should be created for agro-dealers to ensure the provision of more diversified seeds and fertilizers, even in remote rural areas. This would imply significant investment in rural roads.

Transparent and open competition: For bid processes in the allocation of government grain import contracts and licences to be transparent and open, it is necessary to strengthen sub-national mechanisms for monitoring and preventing graft, exploitation and corruption in the operation of public and state-owned operations.

\section{Work and wages}

The most effective and durable way to achieve inclusive and equitable growth is through the creation of safe and remunerable employment opportunities for all. This is paramount for Malawi, where access to decent paid work is not inclusive and is not a driver of poverty reduction. At the root of the problem is the structure of the Malawian economy, which is in desperate need of diversifying away from its reliance on subsistence agriculture and the informal non-agriculture sector that, along with a huge unpaid work burden falling heavily on women and girls, is propping up the economy.

The greatest majority of the employed population is employed in the informal sector ( $83.8 \%$ of men and $93.6 \%$ of women); about $60 \%$ of the working population is in precarious employment, ${ }^{162}$ and women experience higher rates of unemployment. ${ }^{163}$

Just over a third (36.3\%) of all workers in rural areas are in paid employment. These are usually agricultural workers employed in large estates producing tobacco, tea, sugar and coffee; they are often landless or own so little land that they need to complement their earnings with wage labour. They often work in precarious and unsafe conditions, and their wage falls below the poverty line. This is also true in sectors which do comply with the national minimum wage, such as the tea industry. The tea industry is the largest formalsector employer in the country, employing 50,000 workers. An 0xfam ${ }^{164}$ study in 2013 found that tea pluckers received a wage that complied with the legal minimum wage but was still below the international extreme poverty line at household level, and only reached the national poverty line when additional in-kind transfers were included. Wages paid in the sector were not significantly different from wages paid in other sectors.
IIIIIIIIIIIIIIIIIIIIIIIIIIIIIIIIIIIII

THE MOST EFFECTIVE

AND DURABLE

WAY TO ACHIEVE

INCLUSIVE AND

EQUITABLE GROWTH

IS THROUGH THE

CREATION OF SAFE

AND REMUNERABLE

EMPLOYMENT

OPPORTUNITIES FOR

ALL.

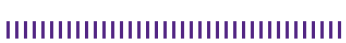


Malawi's minimum wage has been among the lowest in Africa, ${ }^{165}$ despite having been increased from MWK 19,000 (\$26) to MWK 25,000 (\$35) per month in 2017. ${ }^{166}$ The minimum wage is not linked to the cost of living, and the devaluation of the Kwacha and the country's ever-rising inflation mean that the gap between the minimum wage and the true value of the living wage is increasing. This needs to be weighed against the fact that the mean (gross) labour income per month in 2013 was MWK 50,300 (\$69) for men and MWK 30,500 (\$42) for women. ${ }^{167}$ The result is that poorer women in particular are having to combine ever more precarious work with unpaid care responsibilities.

Within the formal sector, there is evidence of a steep remuneration scale, leaving Malawi with the largest wage gap between the lowest- and highest-paid jobs among Southern African countries in 2010: executives were earning 106.7 times more per month than the lowest-paid workers. ${ }^{168}$

Women in Malawi are highly economically active, yet far fewer women than men have formal jobs, and women are instead over-represented in the most unstable, lowest-paid and lowest-skilled (both agricultural and non-agricultural) rural work, ${ }^{169}$ as well as in unpaid care work. Overall, women face greater difficulty translating their labour into paid work; $59 \%$ of working women are likely not to be paid for their work (15- to 19-year-olds are least likelyl, while just $30 \%$ are paid in cash only. ${ }^{170}$

\section{Creating decent jobs and more equal pay}

MGDS III is set to focus on realising a productive, competitive and resilient nation. This will only happen if the implementation of the strategy is geared towards the creation of more and better employment and income-generation opportunities for all, and ensures that economic growth doesn't leave anyone behind. Social groups that need particular attention are women, young women and men, and people with disabilities. These groups are more often found in the informal sector.

A priority for the MGDS III must be to integrate the informal sector, outlining ways in which informal sector organizations and workers, especially women's organizations and groups, are central to the strategy's delivery. Specific, urgent initiatives to integrate the informal sector into the delivery of MGDS III are as follows:

- Provide special services to workers in the informal economy, including information on their legal rights, skills and literacy projects, legal aid, credit and loan schemes, and the establishment of effective mixed and women-only cooperatives. Services should be responsive to the specific needs of and responsibilities falling on women and girls, notably unpaid care work and safety at and around the workplace.

- Take steps towards the recognition of informal jobs and the inclusion of informal workers in legal frameworks regulating work conditions, especially minimum wages, freedom of association for men and women, and access to social protection, sick pay, maternity and paternity provision. This should include a special focus on the most precarious work, on women, and on small and medium enterprises in the informal sector.

Steps to increase income and benefits from employment include the following:

- Ensure that the minimum wage matches the living wage, and that the minimum wage is enforced in both the formal and informal sectors, for both men and women. Compliance with this should be a condition of all companies operating in Malawi.

- Establish in all sectors of employment - including special economic zones - social protection floors, minimum working conditions, childcare provisions, living wage levels, macroeconomic policies geared towards full employment, and re-regulation of the informal sector.
IIIIIIIIIIIIIIIIIIIIIIIIIIIIIIIIIIIII

MALAWI'S MINIMUM

WAGE HAS BEEN

AMONG THE LOWEST

IN AFRICA.

IIIIIIIIIIIIIIIIIIIIIIIIIIIIIIIIIIIIIII

IIIIIIIIIIIIIIIIIIIIIIIIIIIIIIIIIIIIII

A PRIORITY FOR
THE MGDS III MUST
BE TO INTEGRATE
THE INFORMAL
SECTOR, OUTLINING
WAYS IN WHICH
INFORMAL SECTOR
ORGANIZATIONS
AND WORKERS,
ESPECIALLY
WOMEN'S
ORGANIZATIONS
AND GROUPS,
ARE CENTRAL TO
THE STRATEGY'S
DELIVERY.

IIIIIIIIIIIIIIIIIIIIIIIIIIIIIIIIIIIIIII 
Closing the divide in Malawi

How to reduce inequality and

increase prosperity for all

\section{FISCAL JUSTICE: THE FAIR APPROACH TO REDUCING INEQUALITY}

A well-designed tax system that redistributes wealth and enables spending on public services is one of the most effective ways for a government to reduce inequality and poverty, while sustaining growth. ${ }^{171}$ Taxing the wealthiest in society more, and taxing profits of companies - particularly large, successful corporations - is one of the most progressive forms of taxation. Taxation raises public finance for investing in public services, which in turn reduces poverty and inequality when it redistributes the income by enabling poor people to fulfil their rights to good healthcare and education. ${ }^{172}$

Despite having a relatively progressive taxation system (as discussed below), Malawi is constrained by its poor capacity and flexibility in raising additional public income from taxation, as well as by the structure of its economy, which results in a narrow tax base. Total tax revenue amounted to $16 \%$ of GDP in 2015/16. ${ }^{173}$

Weakness in public finance management, compounded by a shift of a significant share of donor aid to off-budget mechanisms, has resulted in a vicious cycle of rising debt, high inflation, high interest rates and poor business confidence, which discourages investment and in turn reduces tax-raising potential. Indeed, by 2016, Malawi's external debt payments were around $\$ 200 \mathrm{~m}$, using up over $18 \%$ of government revenue and consuming significantly more funds than in the entire health budget. ${ }^{174}$ Even more concerning is the growth of domestic debt, which quadrupled in four years and by 2016 had reached $21.1 \%$ of GDP. ${ }^{175}$

The fiscal position has been improving in the last year, but remains unable to match expenditure demands. There is scope for the government to further enhance its tax-raising potential and bring more equity and gender responsiveness to the tax system, at the same time as improving public spending on areas like health, education and social protection programmes. However, Malawi's tax revenue potential will only improve at any scale with the growth of the economy.

\section{Public finance}

National public finance has been found to be more stable, better aligned with government priorities, more balanced between investment and recurrent expenditure, and easier to implement than donor-funded spending. This underscores the importance of mobilizing domestic resources to the extent possible. Yet even with increases in domestic revenue collection, the needs are enormous. Domestic resource mobilization will therefore not be sufficient on its own to tackle poverty and inequality in Malawi, and as such, aid will remain vital in the short and medium term.

\section{Progressive taxation}

The most powerful means the government has to raise domestic resources in a progressive way is taxation. Despite the structural and fiscal constraints Malawi faces, its tax system is relatively progressive. According to Oxfam's 'Commitment to Reducing Inequality Index', ${ }^{\prime} 76$ Malawi is ranked number one among low-income countries in terms of progressive structure and incidence of tax. Compared to other countries in the sub-Saharan Africa region, Malawi ranks fourth. ${ }^{177}$ Nevertheless, more can be done to increase equity in the system and collect more revenue from taxation. Raising more tax revenue is paramount for Malawi to create resources which can be invested in free, quality healthcare and education for the whole population. 
Closing the divide in Malawi

How to reduce inequality and

increase prosperity for all

Indirect taxation: Governments often choose to rapidly increase revenue from regressive forms of taxation, or to prioritize the pursuit of efficiency of the tax system over its progressiveness. This must be avoided, because it shifts the burden of taxation on to the poorest, especially women, increasing income and gender inequality rather than reducing it. For example, flat indirect taxes such as value-added tax (VAT), which fall disproportionately on poor people, make up on average $67 \%$ of tax revenues in sub-Saharan Africa. ${ }^{178}$

It is worrying that Malawi's 2016 reforms have introduced more regressive rates into the VAT system. Water, bread and laundry soap - all essential products that the poor rely upon - are now subject to the standard $16.5 \%$ VAT rate. ${ }^{179}$ The lowest income groups, and especially the women-headed households that dominate these groups, will be hit particularly hard by these changes. Donors did not come out strongly against the introduction of such regressive policies. Meanwhile, luxury items like plasma TVs, which only the rich can afford to buy, are subject to the same VAT rate. VAT is the main source of tax revenue in Malawi (providing about 34\% of total revenues and equivalent to $5.6 \%$ of GDP in 2014), ${ }^{180}$ and the 2016 reforms reducing tax exemptions, including on essential items, are expected to increase the contribution of VAT by $0.8 \%$ of GDP. ${ }^{181}$ However, the VAT system can be made more progressive by introducing zero rating on or exempting essential items, placing the standard VAT on more non-essential items, and putting a higher VAT rate on luxury items and real estate.

Malawi's 2016 reforms imposed a tax on water making it more expensive. Photo: Daud Kayisi/ Oxfam in Malawi

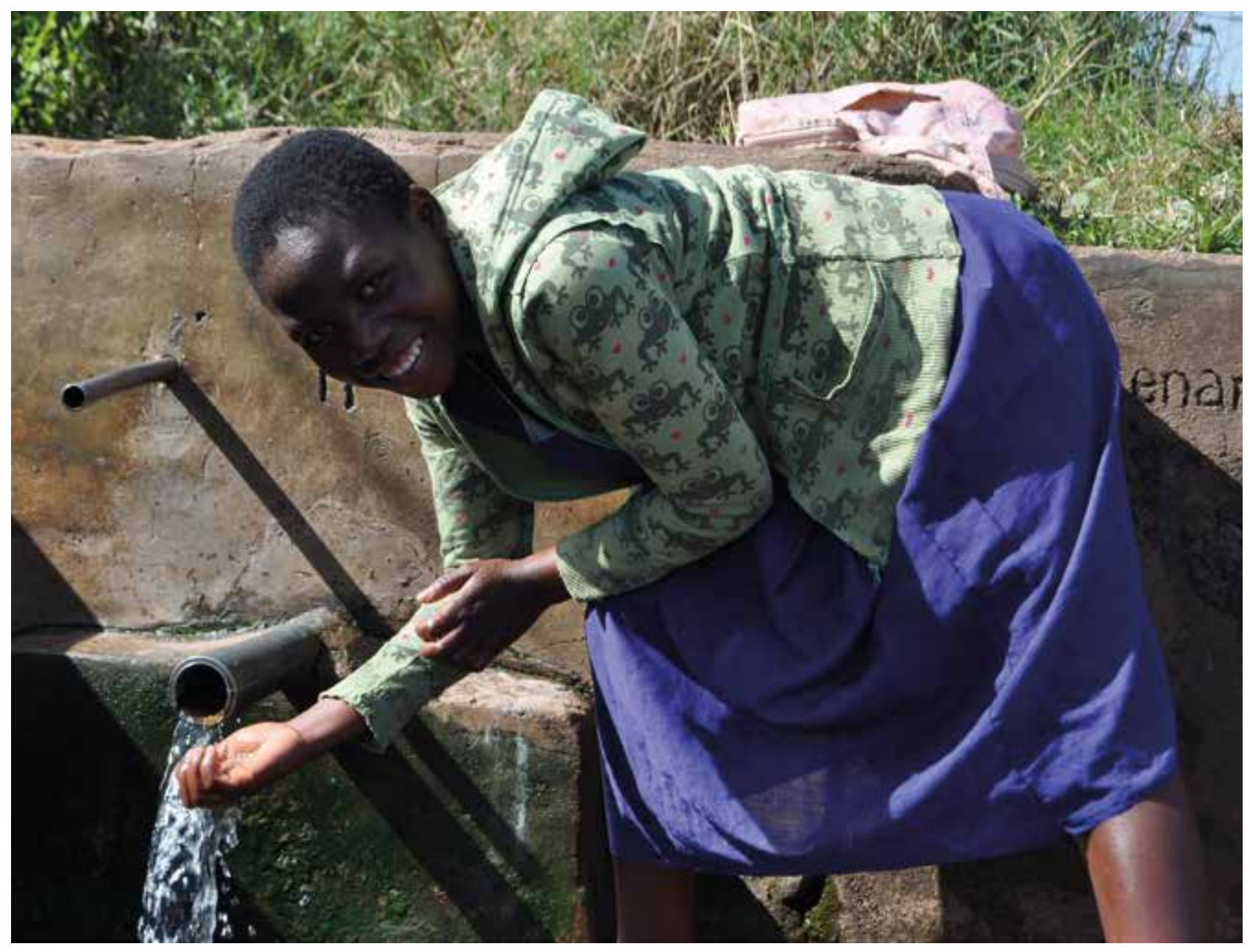


Direct taxation: There is also room to adjust direct taxes to make the tax system more progressive. At one end of the scale, personal income tax (PIT) can be better used to redistribute income to those on the lowest income, by raising the bottom income tax threshold towards the recommended rate of $1 \%$ of GDP per capita, compared to Malawi's $0.2 \%$. At the same time, revenue levels can be maintained by adding a new higher tax bracket for the highest 10\% earners. More can also be done to raise more tax from Malawi's wealthiest residents by introducing more taxes on wealth, or introducing capital gains tax (CGT). Currently, capital gains are considered as part of a person's total taxable income and are not subject to a separate tax rate. ${ }^{182}$

Taxing corporations: ${ }^{183}$ Malawi's corporate income tax (CIT) rate at $30 \%$ is in line with many sub-Saharan countries. It provides just $12 \%$ of total revenues, a contribution which is low when compared to most other Southern African countries, although explained in part by the structure of the economy. But Malawi could do more to raise tax from companies without changing the CIT rate. Based on Malawi's tax effort index (which measures the ratio between actual and potential tax revenues), there is potential to increase tax revenues considerably by reducing the large tax exemptions and deductions afforded to corporations (and wealthy individuals).

Overall, tax expenditure (the sum of exemptions and deductions) in Malawi amounts to $2.2 \%$ of GDP, which is nearly half of what is spent in education (which amounts to $5 \%$ of GDP in 2015), and nearly equal to what is spent in health (2.45\% of GDP in 2015). ${ }^{184}$ More tax revenue could be raised from foreign companies operating in Malawi by introducing more balanced bilateral tax treaties, as current treaties limit Malawi's ability to tax foreign companies. For example, the UK-Malawi tax treaty places restrictions on taxation of British companies. In 2010, British private investments in Malawi amounted to $\$ 157 \mathrm{~m}$, equivalent to $13.7 \%$ of all foreign investment in the country. ${ }^{185}$ The treaty does not allow the Malawian government to charge withholding taxes Itaxes on certain financial flows leaving Malawil to British companies. This means that UK multinational corporations can freely move money out of Malawi via interest or management fee payments, dividends or royalties, without making any tax contributions. ${ }^{186}$

A similar treaty exists with the Netherlands, and has been used by the Australian mining company Paladin to lower its tax bill with Malawi through the use of a subsidiary in the Netherlands with no employees. ${ }^{187}$ To put an end to this profit-shifting, the Malawian government should work with bilateral partners to renegotiate all existing tax treaties, in line with internationally agreed recommendations, to ensure that multinationals operating in Malawi pay their full and fair share of tax. ${ }^{188}$ It is also highly likely that important corporate tax revenues are being lost through foreign corporations shifting profits out of Malawi to corporate tax havens to dodge their tax liabilities. It is difficult to know exactly how much is being lost this way, because these flows are difficult to capture. Estimates from a recent report show that the current estimate stands at $\$ 90 \mathrm{~m}$ for 2013, equivalent to over $2 \%$ of GDP. ${ }^{189}$

Repatriating tax revenues from artificial profit-shifting depends on the Government of Malawi as well as the international tax system and bilateral negotiations with some foreign governments - often also donors to Malawi - to adopt policies that ensure companies publish financial reports of their operations in Malawi, to enable the government and citizens to see how much profit they make and how much tax they pay. Those foreign governments need to establish public registers of the owners of financial wealth using their financial institutions, and share that information with the Malawian government so its tax authorities can collect taxes from wealth made in Malawi and end tax evasion.
IIIIIIIIIIIIIIIIIIIIIIIIIIIIIIIIIIIII

THERE IS ALSO ROOM

TO ADJUST DIRECT

TAXES TO MAKE THE

TAX SYSTEM MORE

PROGRESSIVE.

IIIIIIIIIIIIIIIIIIIIIIIIIIIIIIIIIIIIII

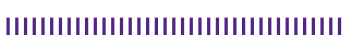

THE MALAWIAN

GOVERNMENT

SHOULD WORK

TO RENEGOTIATE

ALL EXISTING

TAX TREATIES,

TO ENSURE THAT

MULTINATIONALS

OPERATING IN

MALAWI PAY THEIR

FULL AND FAIR

SHARE OF TAX.

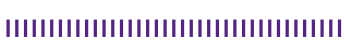


What the government of Malawi, supported by donors, can do, is make efforts towards strengthening tax capacities and public finance management, to help close the gap between the country's tax potential (based on the its economic size and structure) and the tax actually collected.

\section{Extractives}

Raising more revenue does not only rely on raising rates of taxation. The extractive sector is a potential and very progressive source for increased revenue mobilization. Revenue potential for governments exists at least at five levels: (i) 'non-tax' royalties on production value; (ii) corporate income tax on profits; (iii) resource rent tax on 'super profits'; (iv) withholding taxes on payments to foreign companies; and (v) government's equity in the project. However, revenue potential is frequently not realised and the benefits of the extractive sector are most often not palpable for the communities involved, i.e. those who work in the industry or live locally. Women in particular face systemic discrimination at all phases of extraction - from land being expropriated, risks from the influx of transient workers, the transition to cash economies, impacts on water and wood availability and associated increases in unpaid care work, and changes in power balances within communities. ${ }^{190}$ Pursuing extractives as a revenue source can therefore fuel inequality, especially if companies are poorly regulated, and revenues are captured by a few individuals and not fairly shared with the mining communities.

The share of non-tax revenues going to Malawi's national budget in $2015 / 16$ was only $2 \%$ of GDP, 191 one of the lowest rates among Southern African countries, and revenues collected from the extractives sector have so far not met the government's expectations. The government is promoting investment in the extractive industries, with the aim of revenues reaching 20\% of GDP in 2020; however, in 2014, mining and quarrying only constituted about $3.1 \%$ of total GDP. ${ }^{192}$ This is due in part to long timelines from discovery to production, the global slump in commodity prices, and the fact that investment incentives offered to the main foreign investor, the Australian mining company Paladin, ${ }^{193}$ have not led to the expected returns. Box 6 highlights some of the limitations of revenue raising from mining. It shows that increased potential revenues from mines like Songwe Hill could be important but are not 'game-changing', and therefore must not be overstated or given undue focus. Mining is definitely not a solution to the Malawian government's need to raise more domestic resources, nor is it a reason to ignore illicit financial flows.

\section{BOX 6. OXFAM'S CASE STUDY OF THE RARE EARTH DEPOSIT PROJECT IN SONGWE HILL ${ }^{194}$}

The Canadian company Mkango held a licence for exploration rights to Songwe Hill, which expired in 2017. ${ }^{195}$ Rare earth elements are a very promising commodity, but the market is still relatively small and the commodity price would need to increase substantially for the project to be profitable. Even if that happens, production could not start until 2020. The legal framework for revenues to be generated does exist, but it would need to be properly implemented. Oxfam estimated that, provided a price increase makes the project viable, government revenues could reach $\$ 20 m-50 m$ per year. ${ }^{196}$
|||||||||||||||||||||||||||||||||||||||

MINING IS

DEFINITELY NOT

A SOLUTION TO

THE MALAWIAN

GOVERNMENT'S

NEED TO RAISE

MORE DOMESTIC

RESOURCES NOR

IS IT A REASON

TO IGNORE ILLICIT

FINANCIAL FLOWS.

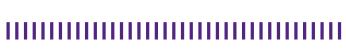




\section{Closing the divide in Malawi \\ How to reduce inequality and \\ increase prosperity for all}

In the Mines and Mineral Policy 2013, the government committed to developing a viable and transparent fiscal and taxation regime that attracts investors in the minerals sector and ensures that a substantial amount of revenue is retained in Malawi. This is, however, yet to materialize. The government needs to ensure that companies pay what they owe, backed by legislation and monitored through routine audits.

It also needs to put in place mechanisms which ensure that when incentives are created to attract foreign investment in mining, revenues are raised from the profits made by these companies and these revenues are redistributed to all, especially the mining communities.

Civil society organizations, including women's rights organizations, will need to be supported to hold the government and mine operators to account in terms of negotiating and enforcing mining agreements, including in relation to compensation arrangements, environmental impact, local jobs, materials or other content and revenue sharing. The government should also consider the realistic potential government revenues when negotiating a contract or investment with a mining company, based on a solid forecast of mineral production and project costs.

\section{International aid}

Malawi relies heavily on international aid as a source of public finance. Around $40 \%$ of the national budget was funded by international donors in 2015. ${ }^{197}$ The majority of donor aid is dominated by a small number of donors, including the US, the UK, the EU and the World Bank. ${ }^{198}$ Donor support to Malawi has undoubtedly contributed to progress in life expectancy and human development, particularly in health and primary education. Even though Malawi should ultimately transition away from donor finance, the country will continue to need substantial aid in the medium term - more than it is currently receiving - to maintain public expenditure. It will also continue to need aid to help explore and develop future alternative revenue streams, as well as to support climate change adaptation and mitigation.

Given the scale of need and the historic and continued high level of aid, donors are both very powerful - and highly responsible - for tackling poverty and inequality in Malawi. Aid must be channelled effectively to ensure government systems are not undermined, and as such invested in sectors that support equitable and sustainable growth. Negative impacts of aid like dependence can be mitigated where finances are channelled via government systems, and doing so facilitates an easier transition to domestic resource mobilization. Sadly in the last five years the quality of donor aid has fallen (figure 9). In addition, the suspension of direct donor aid has contributed to government adoption of regressive policies that have driven up inequality and hurt the poor. This includes the removal of exemptions for VAT on basic goods and food used by the poor and imposition of types of user fees in hospitals which have had a negative impact on the health of the poorest.
IIIIIIIIIIIIIIIIIIIIIIIIIIIIIIIIIIIIIII

GIVEN THE SCALE OF NEED AND HISTORIC

AND CONTINUED

HIGH LEVEL OF

AID, DONORS ARE

BOTH POWERFUL

AND HIGHLY

RESPONSIBLE FOR

TACKLING POVERTY

AND INEQUALITY IN

MALAWI.

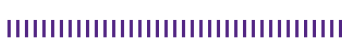


Closing the divide in Malawi

How to reduce inequality and

increase prosperity for all

Oxfam sees three priority approaches for aid spending in Malawi:

- Aid needs to be targeted at strengthening governance of public institutions (legal, fiscal, political, cultural, etc.) so they are accountable to all citizens (including women, young people, people with disabilities, etc.). This requires investments in public financial management, and in strengthening tax systems to narrow some of the key tax gaps.

- Aid needs to support civil society and citizens' efforts - particularly those of women and marginalized people - to actively engage in public (including budgetary) decision making on issues that affect their lives, and to monitor government performance, holding it to account in its delivery of services and protection of citizens' rights.

- Aid needs to support the government to ensure good quality, free universal public healthcare and education, and to provide social protection. These interventions are essential for reducing inequality and poverty.

In response to the Cashgate scandal, donors have suspended a large portion of budget support grants, ${ }^{199}$ and instead increased their off-budget aid. ${ }^{200}$ The withdrawal of such a large amount of predictable, on-budget aid has had a serious negative impact on critical public services. For example, in 2012, over two-thirds of Malawi's health sector was funded by aid. ${ }^{201}$ By 2014-15, planned on-budget health spending by donors fell by almost 99\%.202 Maternal mortality rates rose during this period. ${ }^{203}$ While aid levels have since increased and returned to former levels, aid has been channelled more through piecemeal projects, leaving critical services within the sector vastly underfunded. Funnelling aid through parallel systems in this way also undermines state capacity. Donors must act to reverse the downward trend in aid quality across sectors and a multitude of performance measures.

In recent times, the media have reported that there has been corruption at a local government level through the misuse of Local development Fund (LDF), Constituency Development Fund (CDF) and District Development Fund (DDF)

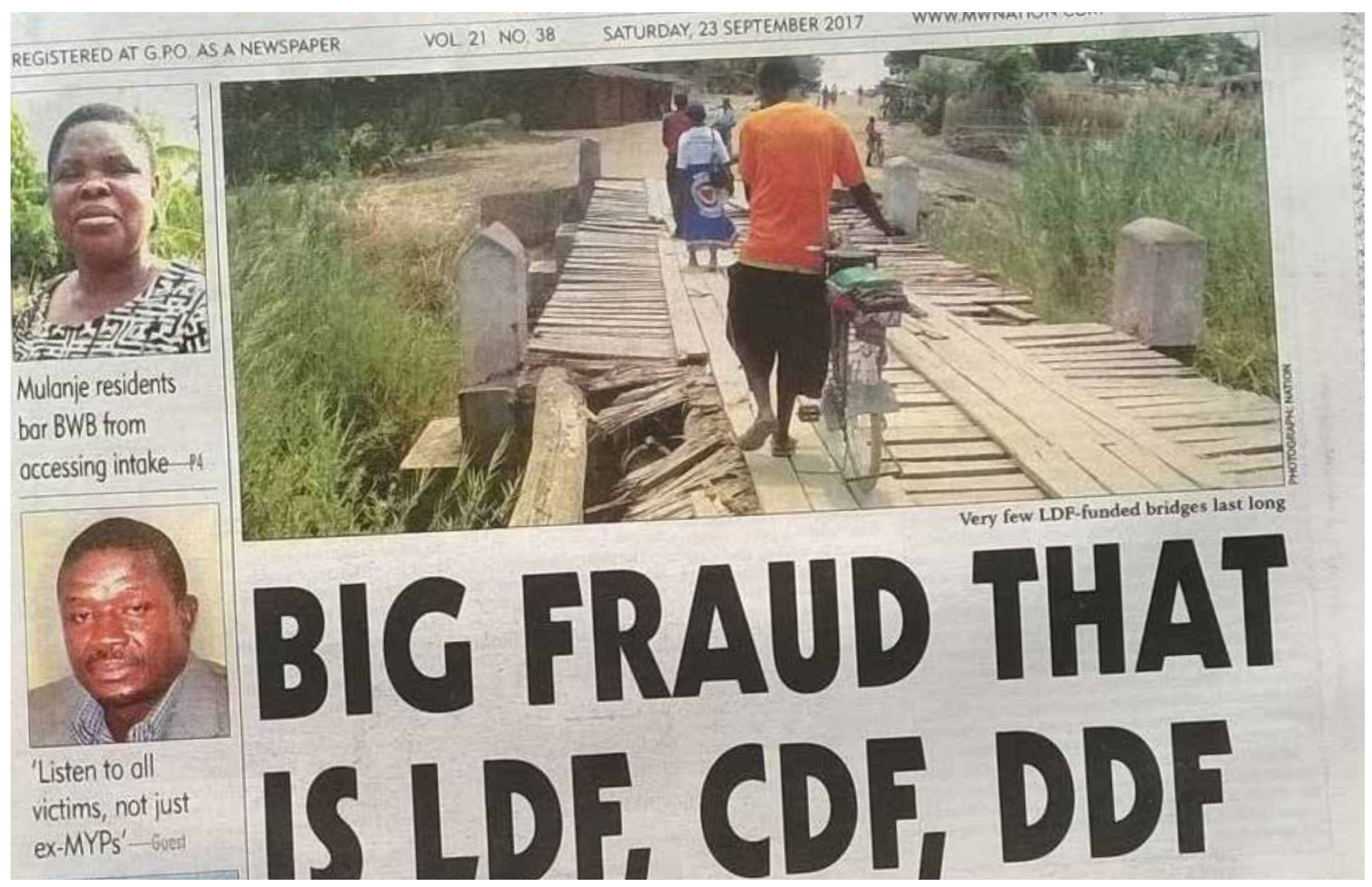


Closing the divide in Malawi

How to reduce inequality and

increase prosperity for all

Figure 9: Overseas development aid (ODA) performance against key measures of aid effectiveness, 2010-2015

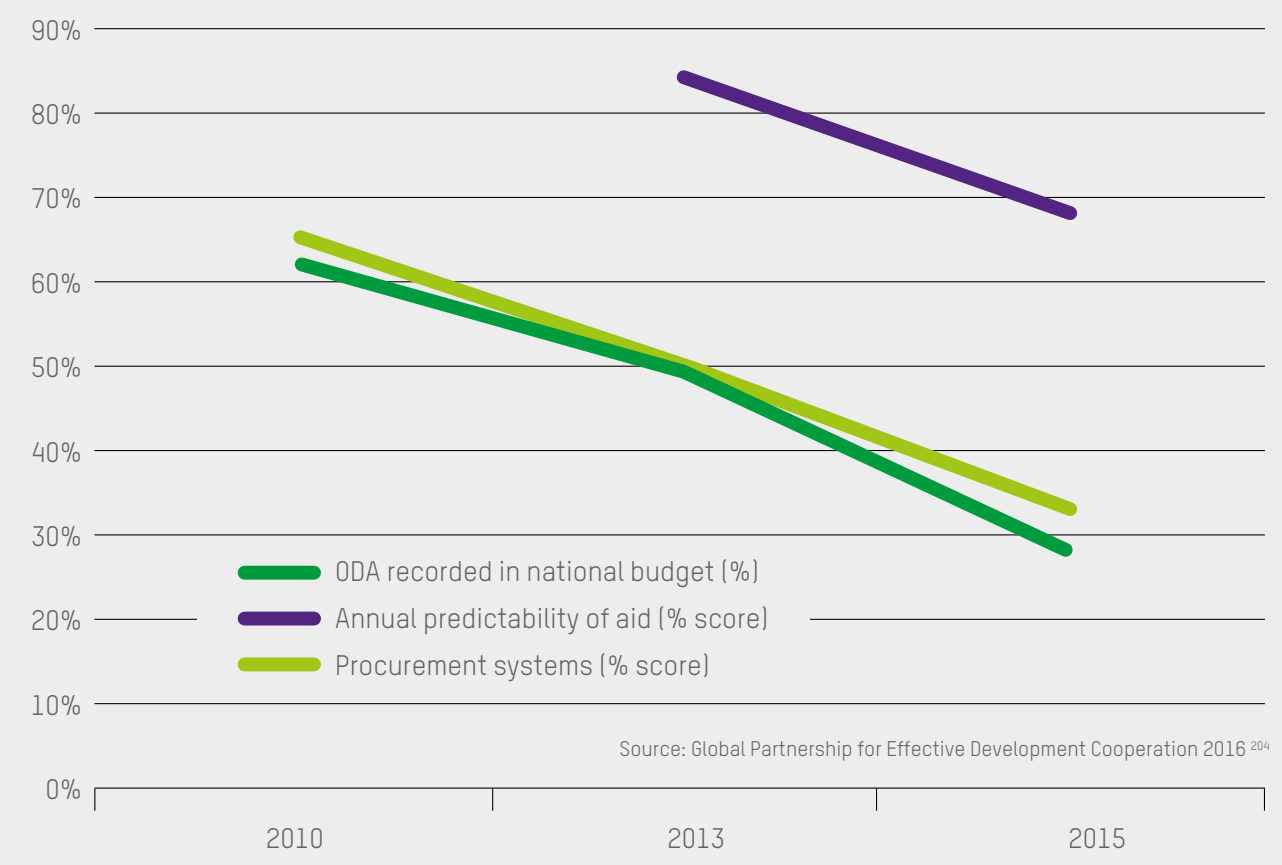

Restoring budget support is the most urgently needed action donors should take to enhance aid quality and ensure funding of critical government interventions and services. This requires Malawi to hasten efforts to demonstrably improve its public financial management (e.g. through target monitoring), and to tackle corruption. The importance of government action in strengthening governance and rooting out corruption cannot be overstated. Yet it is also incumbent on donors to support the government in making these improvements through funding stronger systems and public accountability mechanisms. Moreover, donors should not wait for corruption reforms to be completed before restoring budget support or financing government systems, as the cost to the long-term fight against poverty and inequality would be too high. There are many ways in which donors can ensure that their aid is doing all it can to support government systems and not undermine them.

Donors must also urgently increase aid levels to Malawi for the medium term, particularly in light of its debt servicing obligations. ${ }^{205}$ Malawi needs grants from donors, not the added burden of servicing loans to banks and government lenders.
IIIIIIIIIIIIIIIIIIIIIIIIIIIIIIIIIIIII

MALAWI RELIES

HEAVILY ON

INTERNATIONAL AID

AS A SOURCE OF

PUBLIC FINANCE.

IIIIIIIIIIIIIIIIIIIIIIIIIIIIIIIIIIIIIII 


\section{Public spending}

Progressive and effective public spending is the other side of the fiscal justice coin. Spending on free public services benefits everyone, but provides greater benefits to the poorest. ${ }^{206}$ Access to good quality, free healthcare and education is a right and it increases an individual's potential, which in turn creates new opportunities that enable the poorest families to escape poverty. Public services also mitigate the impact of skewed income distribution, and redistribute revenue by putting 'virtual income' into the pockets of the poorest women and men. ${ }^{207}$ The combined factors of expanding social and economic opportunity and redistributing 'virtual income' have an equalizing effect on the haves and the have nots, and free public services are therefore an essential part of an inequalityreduction policy package.

Oxfam proposes three top priorities for increased public expenditure in Malawi: healthcare, education and social protection.

\section{HEALTHCARE}

Prioritize investing in universal health coverage (UHC): Malawi has made a welcome commitment to achieve UHC by 2030, as part of the SDGs. 'The Health Sector Strategic Plan (HSSP II) 2017-22, Towards Universal Health Coverage', commits to 'move towards UHC of quality, equitable and affordable health care with the aim of improving health status, financial risk protection and client satisfaction'. ${ }^{208}$

UHC means all people accessing the healthcare they need without facing financial hardship. ${ }^{209}$ When health services and medicines are not free at the point of use, people may delay seeking treatment or simply go without, which in turn can lead to long-term health complications, loss of income, higher treatment costs and even death. Direct payments for healthcare also push many more people into extreme poverty: almost 100 million people a year worldwide. ${ }^{210}$ Women and girls are especially affected when healthcare is not free. They are most in need of health services, yet have less access to the resources needed to pay for fees; they are often pushed into seeking more and more precarious paid work to cover healthcare costs, while also having to step into the care breach by increasing their own unpaid labour. ${ }^{211}$

By contrast, quality public health services that are free at the point of use are a powerful way to reduce income and gender inequalities. ${ }^{212}$

However, to achieve UHC for Malawi is currently a major challenge and requires ambitious action. The health sector is steeped in a funding crisis and being starved of urgently needed public finance. ${ }^{213} \mathrm{~A}$ quarter of health facilities in Malawi have neither a functioning client latrine or ambulance, and a similar proportion of medical equipment is out of service..$^{214}$ Even more critically, almost half of Malawi's health-worker positions are vacant. ${ }^{215}$ The HSSP II states that budgetary commitments from government and grants from donors to the strategy will total about \$2.2bn over the five years from 2017 - leaving a shortfall of nearly half a billion dollars of what is needed over the period to take the welcome step towards UHC outlined in the strategy. ${ }^{216}$

Abolish regressive user fees and ensure access to free healthcare for all: Despite Malawi's welcome commitment to UHC and protection of patients from financial harm - and its leadership in resisting user fee introduction during the 1990s -, the health sector has been conducting a dangerous experiment with healthcare fees in recent years.217 Bypass fees - fees charged when treatment is sought directly at hospital level, circumventing primary healthcare - are being charged in a number of tertiary hospitals in Malawi. ${ }^{218}$
IIIIIIIIIIIIIIIIIIIIIIIIIIIIIIIIIIIII

"WITH SUCH HEAVY
DONOR RELIANCE,
THE HEALTH
FINANCING SYSTEM
IN MALAWI IS
UNSUSTAINABLE AND
UNPREDICTABLE.
FURTHERMORE,
PLANNING IS MADE
INCREASINGLY
DIFFICULT DUE TO
THE FRAGMENTED
SYSTEM OF DONOR
FUNDS AND LACK
OF ON-BUDGET OR
POOLED FUNDS."
GOVERNMENT OF MLAWI, 'HEALTH
SECTOR STRATEGIC PAAN I,
2017-2022, TOWARDS UNIVERAL
HEALTH COVERAGE'
IIIIIIIIIIIIIIIIIIIIIIIIIIIIIIII

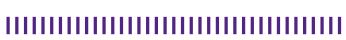

THE UNIVERSAL

HEALTHCARE

MEANS ALL PEOPLE

ACCESSING THE

HEALTHCARE THEY

NEED WITHOUT

FACING FINANCIAL

HARDSHIP.

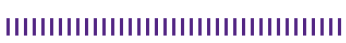


Closing the divide in Malawi

How to reduce inequality and

increase prosperity for all

\section{BOX 7. THE PERSONAL COST OF HOSPITAL BYPASS FEES}

'I am Mrs Mwale and I live in Mzuzu. I am a mother of five and a vegetable vendor. My third-born child died of malaria when she was six years old. In May this year [2015], my last-born child had malaria. I went to our Central Hospital (Mzuzu) for medical attention. I was told I should pay MK 1,500 or go to Mzuzu Health Centre. I only had MK 500 on me.

Knowing that there are very long queues at the health centre, I called my friends and borrowed the money so that I could have my child attended. I didn't want to go and queue and end up losing her. I lost one before and I didn't want to go through the pain again. I was helped out by my friends, paid the MK 1,500 bypass fee, and the child was attended.

My business was, however, not going well. I failed to raise money to repay the friends who helped me. I ended up selling my bicycle that we were using for the vegetable vending business to pay off my debt. I am struggling to make ends meet, but I am happy I have my child with me. With God's grace, I will make some more money and buy another bicycle.' ${ }^{219}$
IIIIIIIIIIIIIIIIIIIIIIIIIIIIIIIIIIIIII

WHILE MALAWI'S

HEALTH SECTOR

IS URGENTLY IN

NEED OF MORE AND

BETTER FINANCING,

USER FEES FOR

TREATMENT, CARE

AND SERVICES HAVE

PROVEN TO BE THE

MOST REGRESSIVE

AND DAMAGING WAY

TO GENERATE FUNDS

FOR HEALTH SYSTEM

COSTS.

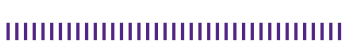

While Malawi's health sector is urgently in need of more and better financing, user fees for treatment, care and services have proven to be the most regressive and damaging way to generate funds for health system costs. User fees rarely contribute more than $5 \%$ to health budgets. 220 Malawi's experiment with bypass fees and fee-paying wards are no exception. Research by 0xfam and partners in 2016 found that finances raised have been minimal, with Kamuzu Central Hospital generating an average of just $9 \%$ of its monthly budget from direct payments, for example.221 Worse still, this research found that most poor people living in urban areas had stopped seeking treatment in hospitals due to the prohibitive bypass fees, and the majority of people in rural areas said they would do the same. ${ }^{222}$ Hospital bypass fees have simply converted the tertiary care referral system into one based predominantly on the ability to pay. 


\section{Closing the divide in Malawi \\ How to reduce inequality and \\ increase prosperity for all}

Other fee-paying services across the health system are also expanding. ${ }^{223}$ Any system where paying fees gives access to higher-quality services, leaving lower-quality services for those who cannot afford to pay, is fundamentally inequitable and incompatible with the values of UHC. Short-staffed hospital doctors and nurses will inevitably spend more time in paying wards, where better services will be expected, leaving those without means to pay, likely in longer queues, with fewer qualified staff and with potential worse health outcomes. ${ }^{224}$ Regardless of intentions, fee paying wards risk creating a two-tier system where access to better quality and faster care is determined by your ability to pay. The Government of Malawi must urgently abolish user fees across its facilities, with immediate suspension of bypass fees and fee-paying wards, to achieve its ultimate ambition of UHC and ensure it leaves no one behind.

Beyond state-run facilities, the government must also implement the recently planned expansion of Christian Health Association of Malawi (CHAM) service-level agreements (SLAs), to ensure an essential health package can be provided for free by CHAM facilities when there is no nearby government clinic. ${ }^{225}$ CHAM clinics provide almost $30 \%$ of all health services in Malawi, yet vary in quality and many charge fees. ${ }^{226}$ It is vital that this policy is now financed and implemented, including through donor backing. Developing the CHAM infrastructure to cover provision of all healthcare and treatment could provide a step towards achieving UHC in Malawi. Improving the geographical distribution of free healthcare - including via these reforms - will also help ease patient transport costs.

Efforts to tackle corruption in the health sector will also be important to address the problem of informal charges and bribes, which punish the poorest the most.

Rule out the introduction of a National Health Insurance Scheme (NHIS): The government has recently considered a proposal to introduce a NHIS. ${ }^{227}$ It is vital that this option is entirely ruled out. For Malawi, an NHIS would exacerbate inequality and leave the poorest women, children, and men behind in access to healthcare. Challenges with enrolment and prohibitive costs are commonplace in insurance schemes in other countries such as Ghana, and are highly likely to be replicated in Malawi. Ten years after the introduction of Social Health Insurance schemes in Ghana, coverage had reached only $36 \%$, due to challenges in enrolling people outside of salaried employment and the high costs of the premiums. ${ }^{228}$ Malawi has recently started rolling out a national ID scheme, but this may face challenges in achieving population-wide enrolment. In countries with large informal sectors, national health insurance schemes become de-factor voluntary. People's inability or unwillingness to prioritise paying health insurance premiums above other urgent goods and services results in large-scale exclusion, particularly of the poorest and most vulnerable in society, who are by majority women. ${ }^{229}$ Indeed, a recent independent review of Ghana's NHIS recommended that free primary healthcare is reinstated because of persistent equity and enrolment issues associated with the NHIS. ${ }^{230}$ Moreover, evidence from other countries has shown that a NHIS scheme is unlikely to raise significant additional revenues for health, especially outside of the formal sector. ${ }^{231}$ In Ghana, premiums paid by the informal sector contribute just $5 \%$ towards the cost of the NHIS. ${ }^{232}$

Restore effective public financing: The majority of countries that have attained UHC have done so by prioritizing public spending on health. ${ }^{233}$ For Malawi, a considerable increase in public spending will be needed to achieve UHC. As Figure 10 below shows, Malawi spends an average $11 \%$ of government expenditure on health. This is only two-thirds of the $15 \%$ Abuja spending target on health agreed by all African governments. ${ }^{234}$ 
Closing the divide in Malawi

How to reduce inequality and

increase prosperity for all

Figure 10: Malawi domestic general government health expenditure as a percentage of general government expenditure, 2012-15

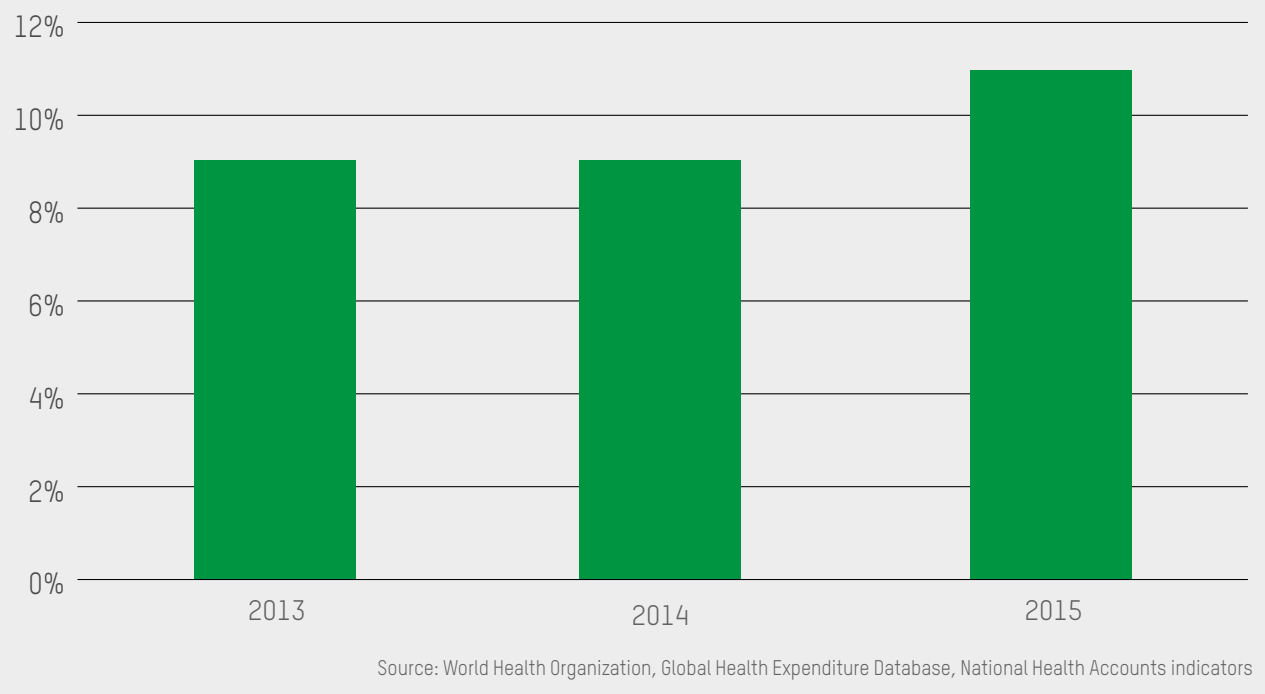

Figure 11 shows a positive rise in public revenue financing for health - albeit alongside growth in regressive private financing. This rise in public financing must continue and the government must meet the Abuja commitment to invest $15 \%$ of total government spending on health. However, while public funding sourced by domestic revenue collection is the best way to fund the health system in the long term, ${ }^{235}$ even with increases in collection, Malawi doesn't have enough resources to achieve health for all. ${ }^{236}$ There can be no escaping that international aid will continue to be essential in supporting Malawi to reach its goal of UHC. Yet, as discussed, donors withdrew health sector government budget support following the Cashgate scandal and donor financing has declined, which has hit the sector hard. ${ }^{237}$

The government has a responsibility to immediately institute good governance provisions to safeguard aid from corruption. But donors must shoulder their share of the responsibility for today's crisis. They should reinstate health sector budget support and ensure HSSP II is fully funded, while attaching considered governance, accountability and transparency conditions to that aid, including strengthened roles of oversight institutions and civil society. ${ }^{238}$ There should also be mutual accountability. Just as recipient countries must ensure that the money is spent as they have committed to spend it, donors must also ensure that they have delivered the monies committed and are adhering to aid effectiveness principles. ${ }^{239}$ This means avoiding piecemeal, short-term, project-based support. Without an increase of on-budget aid to finance Malawi's health sector, there is a significant risk that out-of-pocket payments for health continue to rise to the exclusion of the poorest, and fragmentation and inefficiency are likely to continue to blight the health system. 
Closing the divide in Malawi

How to reduce inequality and

increase prosperity for all

\section{Figure 11: Healthcare financing trends by source}

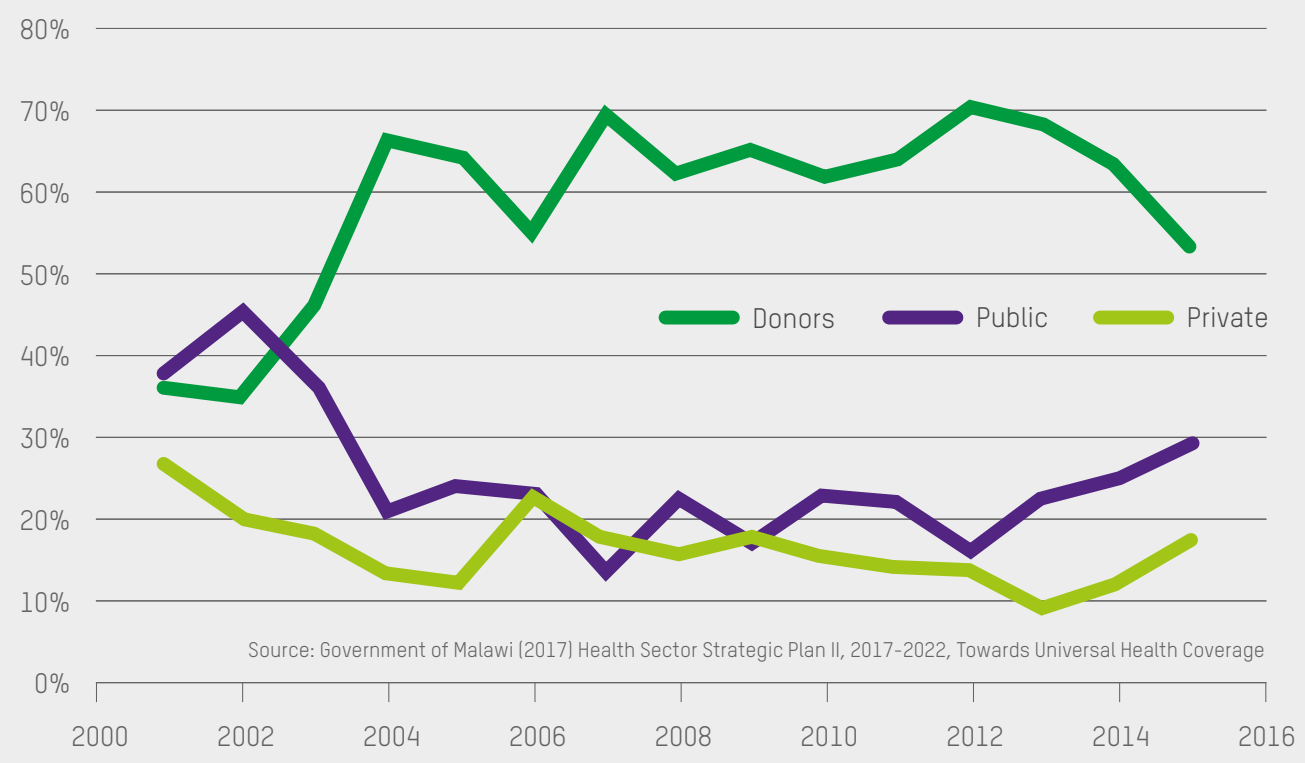

Invest for equity, efficiency and quality: Beyond increased financing, interventions are needed that improve equity and quality in the health system, making it responsive to the needs of Malawi's women in particular. Malawi's maternal mortality rate remains unacceptably high with one in every 157 women giving birth dying of maternal causes. ${ }^{240}$ Investing in Malawi's network of primary healthcare facilities must be another priority. Investment need not be expensive and changes can be achieved quickly. For example, Ethiopia's Health Extension Worker programme trained and deployed 24,000 community health workers between 2004 and 2008. ${ }^{241}$ During this period, child mortality rates fell by almost a quarter, while health expenditure increased from less than \$6 per capita to just under \$14 per capita. ${ }^{242}$ Such investments make economic sense - they help ease overcrowding in costly tertiary hospitals by reducing demand for curative care. The example of Ethiopia shows how limited domestic public resources, augmented by donor support, can go a long way when invested effectively at the primary level.

Investing in capacity to clamp down on leakages from fraud and drug pilferage could also increase cost-savings in the health service. Pilferage of medicines is roughly estimated to cost Malawi \$7.4m annually. ${ }^{243}$ Ensuring the availability and provision of free, quality generic medicines could support these efforts further by minimizing demand for medicines from the expensive private sector market. This would require scale-up of investment in free, quality generic drugs and medical supplies, which is currently estimated to be much lower than in other African countries. ${ }^{244}$

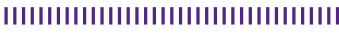

“THE DECLINING

TREND IN EXTERNAL

FINANCING POSES

THE GREATEST

THREAT TO

FUTURE FINANCING

AND PROVISION

OF BETTER

HEALTHCARE IN

MALAWI."

WORLD BANK GROUP. (2017)

FISCAL SPACE FOR HEALTH

IN MALAWI AND REVENUE

POTENTIAL OF 'INNOVATIVE

FINANCING'. WORLD BANK,

WASHINGTON, DC.

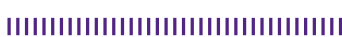


Closing the divide in Malawi

How to reduce inequality and

increase prosperity for all

\section{EDUCATION}

Malawi has made enormous progress since the 1990s in increasing access to public education, especially at the primary level. Malawi was one of the first countries to abolish user fees for primary education in Africa, a move which saw one million new students go to school for the first time. ${ }^{245}$ The provision of good quality, public education is critical to building more equal societies, and particularly for its equalizing effect on gender inequality. ${ }^{246}$ In the early 1990s, the richest children were almost twice as likely to go to primary school as the poorest. Just a few years after the removal of fees, this gap was virtually eliminated. ${ }^{247}$ Many young girls especially got to go to school for the first time, often for the first time ever in their families. Today, the gap between urban and rural areas is also minimal. ${ }^{248}$ Even more impressive is the fact that Malawi has achieved gender parity in primary school attendance: $94 \%$ of girls and $93 \%$ of boys aged $6-13$ now go to school. ${ }^{249}$

Yet despite these huge gains, there are still serious concerns around the quality of both primary and secondary education. At a recent count, $70 \%$ of pupils in Malawi remained illiterate after completing four years of schooling. ${ }^{250}$
Access to quality education is essential for building more equal societies. Photo: Daud Kayisi/ Oxfam in Malawi

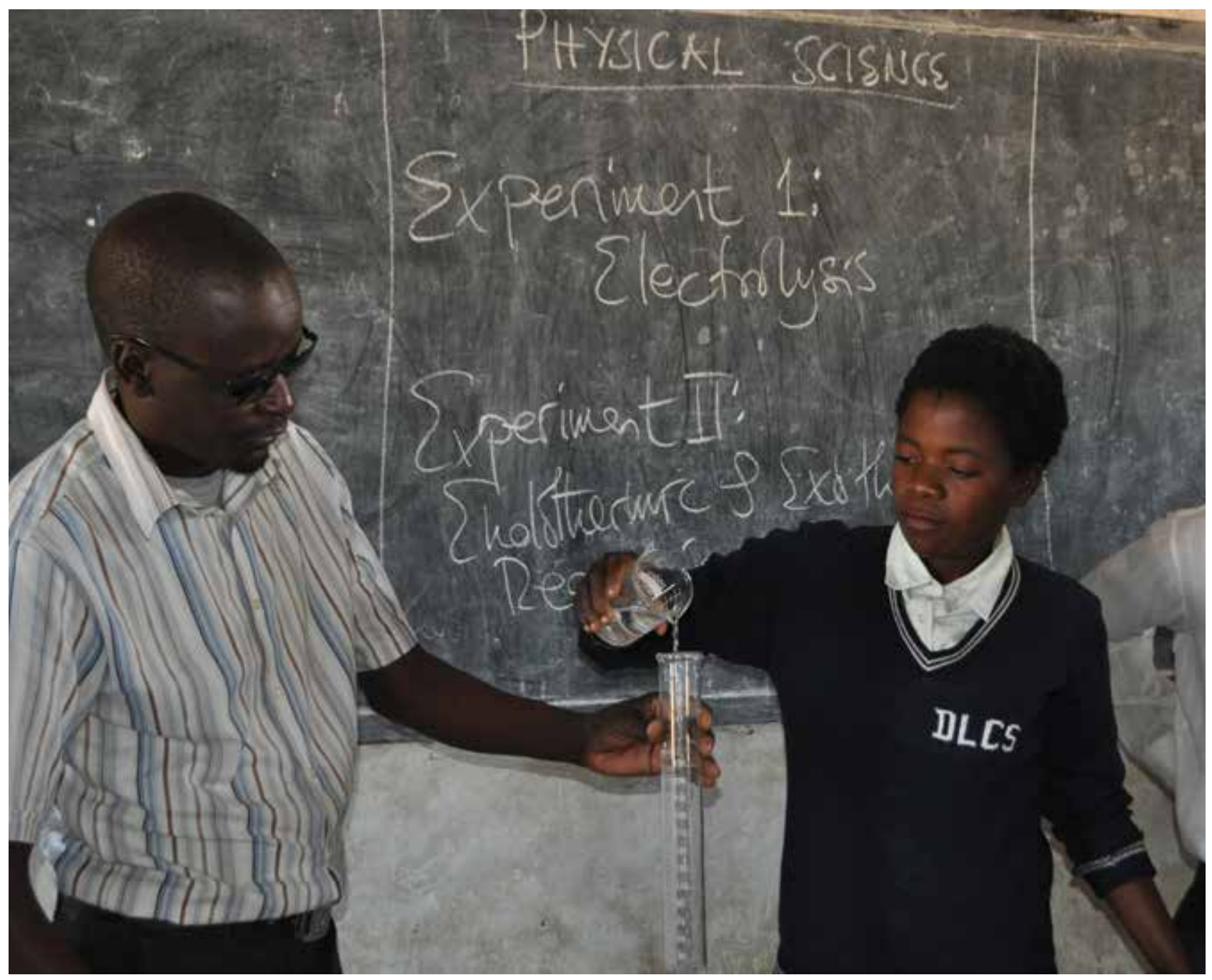


The government has not invested sufficiently in improving the quality of schools in the public sector. At the time of primary fee removal, there was not enough additional investment in the system to cope with the huge surge in demand. ${ }^{251}$ Malawi did not recruit and invest in sufficient numbers of trained teachers and instead met demand with relatively unqualified and untrained staff, many of whom remain in the school system today. ${ }^{252}$ The minimum primary teacher qualification is a two-year certificate that may be insufficient to meaningfully improve quality standards. The teacher shortage also persists, with 78 primary pupils and 44 secondary pupils for every qualified teacher. ${ }^{253}$ Consequently, more and more well-off families are sending their children to fee-paying private schools, where the quality of teaching is often better. One in five secondary school pupils in Malawi is now educated privately. ${ }^{254}$ When only the poorest people are left in public systems, the betteroff have fewer incentives to pay taxes and no self-interest in defending spending on public services, setting in motion a downward spiral of deteriorating quality. ${ }^{255}$ This dynamic only entrenches the inequality divide.

The Government of Malawi must commit to delivering free, quality, public education in order to ensure that Malawian children can fulfil their rights, and to tackle inequality. Oxfam urges action in the following areas.

Meet financing and quality needs: Investment in the public sector is urgently needed. National spending should rise from its current $17 \%$ of the total government budget, ${ }^{256}$ to at least $20 \%$, in line with international targets. ${ }^{257}$ Targets must be met, not only committed to, with no diversion of funds to other government departments. ${ }^{258}$ Investment in teachers is vital to tackle Malawi's education quality crisis, including large class sizes. Critically, more must be done to address the frequent late payment of teachers' salaries, a major factor in high levels of teacher absenteeism. ${ }^{259}$ Quality improvements must also be made across school infrastructure and teaching resources. Malawi's primary school improvement programme (PSIP) - which gave grants directly to schools - had a positive impact on quality, including on the availability of key teaching inputs in schools. ${ }^{260}$ Donors are already contributing more than one-third of total education funds, but with significant gaps still anticipated - including for core costs like teacher salaries -, expanded aid for education is vital. ${ }^{261}$ As with the health sector, this must include the reinstatement of budget support. Donors should pool their funds behind government plans, and should contribute to recurrent costs, to ensure adequate numbers of teachers who are paid a living wage.

Invest more in secondary and tertiary education: Removal of user fees in secondary schools is critical to closing the inequality gap in education in Malawi, and must be a priority policy. Overall secondary enrolment rates are low at 17\%, but the richest children are almost 10 times more likely to attend secondary school than the poorest.262 With fees removed, secondary education must also be made compulsory. Investments in teachers and infrastructure will need to be dramatically increased to keep pace with expanded demand.

Meanwhile, enrolment in tertiary education in Malawi is reported as among the lowest in the world, with less than $1 \%$ of eligible-aged Malawians attending. ${ }^{263}$ Moreover, university education is deeply inequitable, with $82 \%$ of attendees being from the richest families, and many more men than women enrolled. ${ }^{264}$ Subsidies for university students are currently considerably higher than those for primary or secondary school pupils. ${ }^{265}$ Increasing investment in free quality primary and secondary schools must be the priority response to this, both to ensure that young men and women Malawians from different backgrounds are eligible for university in the first place, and to address this spending imbalance. Additional financing of tertiary education will also be required, including continued high subsidies for students from poorer communities or marginalized groups, especially women, and funding to expand university places.
IIIIIIIIIIIIIIIIIIIIIIIIIIIIIIIIIIIIIII

SPENDING ON FREE

PUBLIC SERVICES

BENEFITS EVERYONE,

BUT PROVIDES

GREATER BENEFITS

TO THE POOREST.

IIIIIIIIIIIIIIIIIIIIIIIIIIIIIIIIIIIIIIII

| IIIIIIIIIIIIIIIIIIIIIIIIIIIIIIIIIIIIIII

“THE POOREST YOUNG

WOMEN IN MALAWI

ARE NOT EXPECTED

TO BE UNIVERSALLY

LITERATE UNTIL

2064."

UNESCO (2014) TEACHING AND

LEARNING: ACHIEVING QUALITY

FOR ALL. MALAWI: FACT SHEET.

IIIIIIIIIIIIIIIIIIIIIIIIIIIIIIIIIIIIII 


\section{SOCIAL PROTECTION}

Malawi's social protection policy framework has been strengthened in recent years. The draft MGDS III acknowledges that its success will depend, among other things, on 'the design of effective sectoral and social protection programmes that mitigate root causes of challenges of growth and development, including social and gender inequalities'. ${ }^{266}$ Further, the government has recently completed the roll-out of the Malawi National Social Support Programme (MNSSP), which includes five intervention areas: Social Cash Transfer Programme, School Meals Programme, Public Works Programme, Village Savings and Loans and Micro-Finance.

A recent evaluation of the MNSSP by the International Labour Organization (ILO) has highlighted that despite some improvements in recent years, Malawi's poverty reduction and social protection system falls short of meeting the current and future needs of the country's growing population. ${ }^{267}$ For example, the Social Cash Transfer Programme (SCTP) aims to provide unconditional cash transfers to the $10 \%$ poorest and labour-constrained households in each district, with the goal of reaching 319,000 households. In 2015, the programme was only active in 18 out of 28 districts, and it reached 159,857 households. ${ }^{268}$ Even if the $10 \%$ goal was achieved, the programme would still leave a large number of eligible (ultra-poor and labour-constrained) households without assistance, thereby continuing to leave behind some of the most vulnerable groups.

Overall, the programmes are not providing sufficient resources to those people they reach, and are not reaching many of the poorest and most vulnerable people at all. Lack of resources is a major issue: public expenditure on social protection in Malawi is low by international standards. In 2013, the annual budget for social protection programmes accounted for approximately $2.65 \%$ of GDP, ${ }^{269}$ lower than the average level for low-income countries in Africa. Other problems include high leakage rates, and poor coordination and integration between the different types of interventions. ${ }^{270}$ More resources need to be channelled into the MNSSP to increase coverage and generosity of the interventions. Downsizing the FISP and redirecting these resources into the SCTP as recommended by the World Bank and the International Monetary Fund ${ }^{271}$ is not an answer, as productive subsidies and support are vital to agriculture. Even when they reach the intended beneficiaries, cash transfers have a limited impact on people's productive capacities, unless properly integrated with other interventions. Further, the time gap between the removal of subsidies and the introduction of cash transfers at scale could mean a fall into deprivation and destitution for many.

Malawi needs a more ambitious, large-scale, integrated social protection system, learning from other successful models in Africa. It should focus on universal interventions, such as grants to all mothers, rather than costly and wasteful targeted measures in a country where $70 \%$ live on less than $\$ 1.90$ a day. This will require time and capacity building. The government could start with a pilot based on a limited set of interventions, and then progressively expand activities and link interventions as capacity and experience accumulate. The social protection provisions being included in MGDS III - such as the integration of social protection with agriculture interventions - go in the right direction, but need to be accompanied by the political will and the financial resources to implement them. The 2017/ 18 budget shows signs of greater prioritization of social sector expenditure, with an upward revision to the budgetary allocations for social cash transfers, from MKW $550 \mathrm{~m}$ in 2016/7 to MKW 1.5bn in 2017/18. This is a welcome, although still insufficient, effort.
IIIIIIIIIIIIIIIIIIIIIIIIIIIIIIIIIIIIII

EVEN IF THE SOCIAL

CASH TRANSFER

PROGRAMME

SUCCEEDS WITH

ITS GOAL OF

REACHING 10\%

OF THE POOREST,

THE PROGRAMME

WOULD STILL

LEAVE A LARGE

NUMBER WITHOUT

ASSISTANCE.

IIIIIIIIIIIIIIIIIIIIIIIIIIIIIIIIIIIIIII 


\section{Priority agenda for fiscal justice}

The Government of Malawi faces multiple fiscal and public financing challenges, and needs to take many steps, with the support of international donors and governments, to ensure more progressive revenue raising and increased spending on critical sectors like healthcare and education.

Oxfam's priorities for making progress towards achieving fiscal justice are outlined below.

\section{REFORM THE TAX SYSTEM}

The Government of Malawi should:

- Commit to strengthening and increasing the efficiency of tax systems to collect more tax, particularly from those companies and individuals that shift wealth and profits out of the country to avoid taxation.

- Exempt all basic necessities from VAT and increase VAT on luxury items.

- Launch a review of wealth taxation, with the aim of: introducing an inheritance tax; introducing a net wealth tax; and increasing land rates for the highest value land.

- Reform the personal income tax code by adding a further band for top earners at higher rates, and increase the tax relief threshold to $1 \%$ GDP per capita.

- Ensure all companies - including extractive industry companies - pay what they owe, by not offering wasteful tax incentives and exemptions. Financial details, including tax contributions, should be transparent to enable monitoring by routine audits and holding to account by civil society organizations, including women's rights organizations.

- Take into account realistic government revenue forecasts when negotiating a contract or investment with a mining company.

In addition, international governments should:

- Commit to introducing public country-by-country reporting for all multinational companies in each country they operate in, to enable the government and citizens of Malawi to see the amount of tax paid in the country on the profits made here.

- Establish a public, centralized register of individuals benefiting from ownership of an asset (including shell companies, bank accounts, foundations, trusts, property, etc.) and automatically exchange a central register of beneficial ownership and financial data from their financial institutions with all countries, including developing countries like Malawi, to minimise the practice of profit shifting.

- Ensure that negotiations on tax treaties and cooperation agreements brokered by donors avoid exploiting and eroding developing countries' tax bases.

\section{DEVELOPMENT ASSISTANCE}

The Government of Malawi should:

- Commit to improving governance standards and donor and democratic accountability, including by strengthening public financial management systems through all sectors of expenditure.

- Take the steps outlined elsewhere in this report to tackle corruption, strengthen governance and restore donor trust.
IIIIIIIIIIIIIIIIIIIIIIIIIIIIIIIIIIIIII

THE GOVERNMENT

OF MALAWI

SHOULD COMMIT TO

STRENGTHENING

AND INCREASING

THE EFFICIENCY OF

TAX SYSTEMS TO

COLLECT MORE TAX

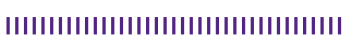


International donors and multilateral institutions should:

- Urgently increase aid levels to Malawi, particularly to the priority sectors and interventions outlined in this report, including free, quality, universal public healthcare and education, agriculture, and an upgrading of the social protection system.

- Restore budget support - both general and sector-specific - and ensure compliance of all aid with aid effectiveness principles, including through use of government systems. Where budget support may take time to reinstate, ensure that transitional mechanisms which directly support government systems are financed, and piecemeal, project-based approaches avoided. These can include virtual pooled funds if required, with financial control outside government, but clearly supporting government plans.

- Target assistance at strengthening governance of public institutions llegal, fiscal, political, cultural, etc.) so they are accountable to all citizens. This requires investments in public financial management, and in strengthening tax systems to collect more taxes. Donors should also support research and national debate to identify appropriate and impactful measures to strengthen governance, incorporating reflections on their own responsibilities and impact.

- Support civil society and citizens' efforts - particularly those of women's and marginalized groups - to actively engage in public (including budgetary) decision making on issues that affect their lives, and to monitor government performance, holding it to account in its delivery of services and protection of citizens' rights.

\section{PUBLIC SPENDING}

The Government of Malawi should:

- Guarantee free healthcare for all citizens, removing all user fees. Implement the proposed CHAM service-level agreement expansion, to ensure everyone can have access to an essential health package which is free at the point of use.

- Abandon unworkable health insurance approaches and instead strengthen the taxbased health financing system.

- Implement national plans to fund healthcare and education, by spending at least $15 \%$ of government budget on healthcare and $20 \%$ on education. Ensure significant investment in raising quality standards across both sectors. In the health sector, ensure a particular focus on investing to improve primary healthcare and training more health workers.

- Develop a costed action plan for the removal of user fees in public secondary schools by 2030 to include financial provisions for an upsurge in pupil numbers. Make secondary schooling compulsory by 2030. Develop a similar plan to increase the level of qualified teachers to meet a minimum intermediate target of a 40:1 pupil to teacher ratio, and strengthen incentives for rural teachers.

- Ensure that the health needs of women and girls are prioritized, with a particular emphasis on reducing the unacceptably high maternal mortality rate among the most disadvantaged women and girls.

- Publish a plan to 'eliminate gender disparities in education' and 'ensure that all girls and boys complete free, equitable and quality primary and secondary education leading to relevant and effective learning outcomes' by 2030, in line with SDG 4.

- Strengthen affirmative action policies to increase access to tertiary education for young people from poor backgrounds and especially young women. Reform the Equitable Access Policy to incorporate socioeconomic status.

- Roll out a large-scale, comprehensive social protection system that meets international targets and minimum standards.
IIIIIIIIIIIIIIIIIIIIIIIIIIIIIIIIIIIIII

INTERNATIONAL

DONORS AND

MULTILATERAL

INSTITUTIONS

SHOULD URGENTLY

INCREASE AID

LEVELS TO MALAWI.

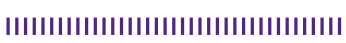

IIIIIIIIIIIIIIIIIIIIIIIIIIIIIIIIIIIIII

THE GOVERNMENT

OF MALAWI SHOULD

GUARANTEE FREE

HEALTHCARE FOR

ALL CITIZENS, AND

REMOVE ALL USER

FEES.

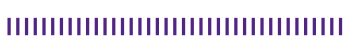




\section{Closing the divide in Malawi \\ How to reduce inequality and \\ increase prosperity for all}

\section{CONCLUSION}

Malawi is an extremely poor country facing considerable development challenges. It is in serious need of investment in its social and economic infrastructure, to drive growth and share growth's gains among all Malawians, to lift them out of poverty and close the inequality divide. Investment in primary education shows how public finance can lead to impressive outcomes. Growth has also had positive ratings in agriculture, Malawi's dominant economic sector. However, poverty levels are not improving. The country has a systemic inequality and exclusion problem, which means many women and men are being left behind. Malawi has limited room for manoeuvre to turn around its development path and reduce inequality, due to several constraints: it has a burden of debt, a narrow tax base and a weak tax system, which hamper domestic resource mobilization; a history of corrupt governance of public institutions; and distrusting international donors who spend their aid outside the government system. These challenges are compounded by a growing population which is experiencing the force of climate change impacts, especially in rural areas.

Acknowledging these constraints, this paper has set out policy solutions that the government and donors can adopt, supported by civil society and others, to change the course of Malawi's future. At the forefront of change must be efforts to tackle the structural drivers of inequality: in Malawi's case weak governance, capture of policy making by an elite and widespread corruption, as well as the pervasive gender disparities that particularly hold back the poorest women and undermine broader growth and opportunity. Reducing these inequalities must be at the heart of all policy.

Growth, however, will not improve unless the government makes efforts to make the economy work for everyone. This means designing agricultural policy and investment that aims to improve the livelihoods of the poorest farmers and workers, rather than serving powerful business interests and land owners. It also means raising more public revenues from national resources, wealthy individuals, and domestic and foreign businesses, to redistribute income and invest in public goods and services for all. Providing universal, good quality, free public services, such as healthcare and education, is a vital part of this picture. Critically, so is donors' and international institutions' financing and supporting of these priority policies, as opposed to pushing problematic models or undermining government systems through a piecemeal approach to aid.

None of these solutions will work if implemented alone or in a vacuum; they are all dependent on each other, and they all demand close involvement of the people they are meant to reach. The vision we present for a more equal Malawi - where no one is left behind - requires the active participation of women and men from all social groups to shape and drive forward action across the range of interconnected issues.

But it is achievable.

IIIIIIIIIIIIIIIIIIIIIIIIIIIIIIIIIIIIIII

AT THE FOREFRONT

OF CHANGE MUST BE

EFFORTS TO TACKLE

THE STRUCTURAL

DRIVERS OF

INEQUALITY: WEAK

GOVERNANCE, CAPTURE OF POLICY

MAKING BY AN ELITE

AND WIDESPREAD

CORRUPTION, AS

WELL AS THE

PERVASIVE GENDER

DISPARITIES THAT

PARTICULARLY HOLD

BACK THE POOREST

WOMEN AND THE

MOST VULNERABLE.

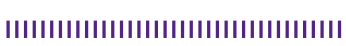




\section{Closing the divide in Malawi How to reduce inequality and \\ increase prosperity for all}

\section{NOTES}

1. Malawi's GDP per capita was $\$ 300.30$ in 2016; among countries for which there is available data, only Burund had a lower GDP per capita in 2016. World Bank, World Development Indicators.

2. The $25 \%$ figure is according to national poverty lines. The remainder of this report will cite the international poverty line of \$1.90 a day; IMF (2017a). Malawi Economic Development Document, IMF Country Report No.17/184, https://www.imf.org/ /media/Files/Publications/ CR/2017/cr17184.ashx.

3. R. Mussa and W. Masanjala (2015). A Dangerous Divide: The State of Inequality in Malawi. Oxfam International. https://oxfamilibrary.openrepository.com/oxfam/ bitstream/10546/582678/1/rr-inequality-in-malawi261115-en.pdf

4. Ibid.

5. R. Mussa and W. Masanjala (2015). A Dangerous Divide: The State of Inequality in Malawi. Oxfam International. https://oxfamilibrary.openrepository.com/oxfam/ bitstream/10546/582678/1/rr-inequality-in-malawi261115-en.pdf

6. Ibid., and see Table 1 (Source: Povcal and National Statistical Office (2012); National Economic Council (2000)).

7. World Food Programme (2016). Malawi Government and WFP Import Maize for Emergency Distribution. http://www.wfp.org/news/news-release/malawigovernment-and-wfp-import-maize-emergencydistribution

8. NSO and ICF (2017). Malawi Demographic and Health Survey 2015-16. Zomba, Malawi and Rockville, Maryland, USA.

9. See Table 1 (Source: Povcal and National Statistical Office (2012); National Economic Council (2000)).

10. Ibid.

11. NSO (2017). Integrated Household Survey 2016/17:

Household socio-economic characteristics report. Malawi.

12. World Economic Forum (2017). The Global Gender Gap Report 2017. http://www3.weforum.org/docs/ WEF GGGR 2017.pd

13. UN Women, UNDP, UNEP and the World Bank Group (2015). The Cost of the Gender Gap in Agricultural Productivity in Malawi, Tanzania, and Uganda. http://www.unwomen.org/-/media/headquarters/

14. See R. Fuentes-Nieva and N. Galasso (2014). Working for the Few: Political Capture and Economic Inequality. Oxfam, p.2. https://www.oxfam.org/sites/www.oxfam. org/files/bp-working-for-few-political-captureeconomic-inequality-200114-summ-en.pdf

15. Nyasa Times, "'Yes", Malawi corruption getting worse, President Mutharika admits', 23 August 2016. http://www.nyasatimes.com/yes-malawi-corruptiongetting-worse-president-mutharika-admits/

16. African Arguments, 'Malawi faces toughest, most high-profile trail yet in massive Cashgate scandal', 8 February 2017. http://africanarguments. org/2017/02/08/malawi-faces-toughest-most-highprofile-trial-yet-in-cashgate-scandal/

17. The Times Group, 'ACB helpless on Bingu Wa Mutharika wealth', 5 April 2017. http://www.times.mw/ acb-helpless-on-bingu-mutharika-wealth/.

18. One recent survey showed that $64 \%$ of Malawians strongly agree' or 'agree' that ordinary people can make a difference in the fight against corruption. Afrobarometer: http://afrobarometer.org/countries/ malawi-0

19. As per the Paris Declaration on Aid Effectiveness, and the Accra Agenda for Action. See OECD, 'Paris Declaration and Accra Agenda for Action' http://www.oecd.org/dac/effectiveness/ parisdeclarationandaccraagendaforaction.htm.
20. NSO and ICF (2017). Op. cit.

21. UNICEF, UNICEF Data: Monitoring the Situation of Children and Women, https://data.unicef.org/topic/ child-protection/child-marriage/ and WHO (2013). Child marriages: 39000 every day, http://www. who.int/mediacentre/news/releases/2013/child_ marriage_20130307/en/

22. UNDP in Malawi (2016). Malawi launches 2016 African Human Development Report, 1 December 2016. http://www.mw.undp.org/content/malawi/en/home/ presscenter/articles/2016/12/01/malawi-launches2016-african-human-development-report.html

23. UN Women (2017). Malawi Parliament adopts amendment to end child marriage. 22 February 2017 available at: http://www.unwomen.org/en/news/ stories/2017/2/news-malawi-parliament-adoptsamendment-to-end-child-marriage

24. NSO and ICF (2017). Op. cit.

25. World Bank, World Development Indicators.

26.UN Women, UNDP, UNEP and the World Bank Group (2015). Op. cit.

27.Defined by the 2013 Labour Force Survey (NSO, 2014 as the share of the employed persons in the age group 15-64 years who, during the reference period of one week, were working as contributing family workers or own-account workers out of the total employment.

28. See Oxfam and ETP (2013). Understanding Wage Issues in the Tea Industry4F. Oxfam and Ethical Tea Partnership. https:/ /oxfamilibrary.openrepository.com/ oxfam/bitstream/10546/287930/1/rr-understandingtea--industry-wage-020513-en.pdf

29. Pricewaterhouse Coopers South Africa (2010). Remuneration trends report in Southern Africa. Pricewaterhouse Coopers. South Africa. www.pwc $\mathrm{com} / \mathrm{za}$

30. FAO (2011). Op. cit.

31. IMF (2015a). Fiscal Policy and Long-Term Growth. https://www.imf.org/external/np/pp/ eng/2015/042015.pdf

32. M. Lawson and M. Martin (2017). The Commitment to Reducing Inequality Index: A new global ranking of governments based on what they are doing to tackle the gap between rich and poor. Development Finance International and Oxfam. July 2017. https:// policypractice.oxfam.org.uk/publications/the-commitmentto-reducing-inequality-index-a-new-global-rankingof-governments-620316

33. Data come from Oxfam's Commitment to Reducing Inequality Index Database, available upon request.

34. A. Cobham and P. Jansky (2017). Global distribution of revenue loss from tax avoidance: Re-estimation and country results. Working Paper 2017-55. UNU-WIDER https://www.wider.unu.edu/sites/default/files/ wp2017-55.pdf

35. IMF (2017b). Op. cit.

36. Global Partnership for Effective Development Cooperation (2016) Malawi Monitoring Profile - October 2016. http://effectivecooperation.org/wp-content/ uploads/2016/10/Malawi_10_10.pdf

37. See Table 2.a for details of decline in budget support grants. IMF (2016) Malawi, IMF Country Report No. $16 / 182$.

38. 'Malawi Case Study'. Jubilee Debt Campaign, http://jubileedebt.org.uk/countries/malawi; and Malawi's planned health spending in 2015-16 was US\$168,425,663 (current US dollar), based on Government Spending Watch data, available at: governmentspendingwatch.org.

39. See 'Malawi Case Study', Jubilee Debt Campaign http://jubileedebt.org.uk/countries/malawi

40. E. Seery (2014). Working for the Many: Public services fight inequality. Oxfam International. http://policypractice.oxfam.org.uk/publications/working-for-themany-public-services-fight-inequality-314724.
41. J. Hamer (2016). The Right Choices: Achieving Universal Health Coverage in Malawi, Oxfam International. https://policy-practice.oxfam.org.uk/ publications/the-right-choices-achieving-universalhealth-coverage-in-malawi-611820

42. Government of Malawi (2017). Op. cit., p.16. 43. In government health facilities. Ibid., p.15.

44. L. Gilson (1997). 'The Lessons of User Fee Experience in Africa'. Health Policy and Planning, 12: 273-285. https://doi.org/10.1093/oxfordjournals.heapol.a018882 45. Originally featured in J. Hamer (2016). Op. cit.

46. Details of proposed CHAM SLA reform were found in Ministry of Health slides, 'Initiatives Improving Access and Coverage in the Context of UHC, HSSP and Reforms', shared with Oxfam in Malawi at UHC workshop, 14-16 April 2016.

47. Ibid.

48. Based on calculations for the financing gap for HSSP II, which includes donor contributions, as outlined on same page of this report.

49. Quoted in C. Averill (2013). Universal Health Coverage - Why health insurance schemes are leaving the poor behind. Oxfam. https://policy-practice.oxfam.org.uk/ publications/universal-health-coverage-why-healthinsublications/universal-health-coverage-why-health-

50. E. Amporfu (2013) 'Equity of the premium of the Ghanaian national health insurance scheme and the implications for achieving universal coverage', International Journal for Equity in Health, 12:4.

51. N. Hall and M. Mambo (2015). Financing Education in Malawi, Opportunities for Action - Country case study for the Oslo Summit on Education for Development, p. 5.

52. S. Al-Samarrai and H. Zaman (2007). 'Abolishing School Fees in Malawi: The Impact on Education Access and Equity'. Education Economics. 15.3, 359-375, p.5.

53. At primary level, net school attendance ratios were at 94.7 for urban areas and 93.8 for rural areas in 2015/16. A gap persists at secondary level, however. NSO and ICF (2017). Op. cit.

54. NSO and ICF (2017). Op. cit.

55. According to a 2013/14 UNESCO factsheet: UNESCO (2014). Teaching and learning: Achieving quality for all. Malawi. Fact Sheet. http://www.unesco.org/fileadmin/ MULTIMEDIA/HQ/ED/GMR/pdf/Malawi Factsheet.pdf.

56. T. Smeeding (2005). 'Public Policy, Economic Inequality, and Poverty: The United States in Comparative Perspective' in Social Science Quarterly. Vol. 86 (suppl): 955-83.

57. Education 2030 (UNESCO et al) (2015) Incheon Declaration and Framework fo Action for the implementation of Sustainable Development Goal 4. http://unesdoc.unesco.org/ images/0024/002456/245656e.pd

58. See for example, the MWK $500 \mathrm{~m}$ education budget cut in 2016 midway through the fiscal year. Nyasa Times, Malawi govt MPs celebrate K500mil cut on education budget', 9 March 2016. http://www.nyasatimes. com/malawi-govt-mps-celebrate-k500mil-cut-oneducation-budget/

59. ActionAid (2017). Low quality of public schools drives parents towards private education in Malawi; and UNESCO (2014) EFA Global Monitoring Report 2013/14, Teaching and Learning: Achieving quality for all, p. 268 60. M. Mambo and J. Salmi (2016). Improving Higher Education in Malawi for Competitiveness in the Global Economy: A World Bank Study. https://issuu.com/world. bank.publications/docs/9781464807985

61. IL0 (2016). Social Protection in Malawi. Assessment Based National Dialogue Brief. International Labour Organization and Irish Aid. http:// www.ilo.org/ addisababa/information-resources/publications/
WCMS_493330/lang--en/index.htm

62. Ibid.

63. Malawi's GDP per capita was $\$ 300.30$ in 2016; among countries for which there is available data, only Burund had a lower GDP per capita in 2016. World Bank, World Development Indicators. 


\section{Closing the divide in Malawi How to reduce inequality and \\ increase prosperity for all}

64 . The $25 \%$ figure is according to national poverty lines. The remainder of this report will cite the international poverty line of $\$ 1.90$ a day; IMF (2017a). Malawi Economic Development Document, IMF Country Report No.17/184, https://www.imf.org/ /media/Files/Publications/ CR/2017/cr17184.ashx.

65. Knight Frank (2016). The Wealth Report 2016.

66. R. Mussa and W. Masanjala (2015). 0p. cit.

67. The Third Integrated Household Survey (IHS3) of $2010 / 11$ considered the ultra-poor to be the population with total consumption below MKW 22,956. NSO (2012) Integrated Household Survey 2010-2011- IHS3. National Statistical Office. Zomba, Malawi.

68. NSO (2017) 0p. cit.

69. Ibid.

70. International Monetary Fund (2017a), IMF Country Report No. 17/184, Malawi Economic Development Document, p.l. https://www.imf.org/ / media/Files/ Publications/CR/2017/cr17184.ashx

71. World Food Programme (2016). Malawi Government and WFP Import Maize for Emergency Distribution. http://www.wfp.org/news/news-release/malawigovernment-and-wfp-import-maize-emergencydistribution

72. H. Moylan (2017), 'Malawi's Fourth Integrated Household Survey 2016-2017 \& Integrated Household Panel Survey 2016: Data and documentation now available', The Data Blog, The World Bank. https://blogs. worldbonk worldbank.org/opendata/malawi-s-fourth-integratedpanel-survey-2016-data

73. NSO (2012). Op. Cit.

74. International Monetary Fund (2017a). 0p. cit.

75. NSO and ICF (2017). Op. cit.

76. Malawi's Human Development Index score alls by $31.2 \%$ in the inequality-adjusted Human Development Index. UNDP (2016). Human Development for Everyone. Briefing note for countries on the 2016 Human Development Report - Malawi. United Nations Development Program.

77. Assuming consumption growth of $10 \%$. R. Mussa and W. Masanjala (2015). Op. cit.

78. In 2015, Malawi was ranked 145 out of 159 in the Gender Inequality Index. UNDP, Gender Inequality Index. Accessed January 2018, at http://hdr.undp.org/en/ composite/GII

79. World Economic Forum (2017). Op cit. http:// www3. weforum.org/docs/WEF_GGGR_2017.pdf

80. Cammack, D. and Kelsall, T. (2010) ‘Developmental Patrimonialism? The case of Malawi'. Africa Power $\delta$ Politics, Woking Paper No.12, July 2010.

81. Ibid.

82. R. Mussa and W. Masanjala (2015). Op. cit.

83. African Development Bank (2010). The Middle of the Pyramid: Dynamics of the Middle Class in Africa, $\mathrm{p}$. 22. https://www.afdb.org/fileadmin/uploads/afdb/ Documents/Publications/The\%20Middle\%20of\%20 the \%20Pyramid The \%20Middle\%20of\%20the \%20 Pyramid.pdf

84. See target 10.1, SDG 10: https:// sustainabledevelopment.un.org/sdgl0

85. See R. Fuentes-Nieva and N. Galasso (2014). Op. cit. 86. R. Mussa and W. Masanjala (2015). Op. cit.

87. Nyasa Times, "'Yes", Malawi corruption getting worse, President Mutharika admits', 23 August 2016. http://www.nyasatimes.com/yes-malawi-corruptiongetting-worse-president-mutharika-admits/

88. See Transparency International, Corruption Perceptions Index 2012, http:/ / www.transparency. org/cpi2012/results\#myAnchorl and Transparency International, Corruption Perceptions Index 2016, http:// www.transparency.org/news/feature/corruption perceptions_index_2016
89. The Nation, 'DPP, ACB at war', 31 December 2016, http://mwnation.com/dpp-acb-at-war/.

90. See VOA News, 'Malawi President Fires Cabinet Minister Over Maize Deal Scandal', 22 February 2017, http://www.voanews.com/a/malawi-presidient-fires cabinet-minister-over-maize-deal-scandal/3735100. html (MWK amount xe.com accessed 18/01/18) and the Guardian, "'I was so hungry I ate water-lilies": southern Africa's food crisis in a dozen dishes', 17 December 2016, https://www theguardian com global-development/2016/dec/17/hungry-ate-waterlilies-southern-africa-food-crisis-dozen-dishes-cropfailure-drought-john-vidal

91. For Cashgate initial figure see The Guardian, 'Money from Malawi "Cashgate" scandal allegedly funded electoral campaigns', 13 February 2015. https:// www.theguardian.com/global-development/2015/ $\mathrm{feb} / 13 /$ malawi-cashgate-scandal-money-fundedelectoral-campaigns. The Government of Malawi's revised education spending for 2012-13 lexcluding donor fundingl was MWK 62,056,206,700. MWK $24,000,000,000$ is equivalent to $38.7 \%$ of this figure. Based on Government Spending Watch data, available at: governmentspendingwatch.org

92. For 2009-2014 figure see Nyasa Times, 'K577bn reduced to K236bn: Malawi "grand corruption" report reveals "big rigging" scheme', 9 July 2016. http://www. nyasatimes.com/k577bn-reduced-k236bn-malawigrand-corruption-report-reveals-big-rigging-scheme/ USD amounts xe.com. 2015-16 revised health budge amount of $\$ 168,425,663$ in current US dollars, according to Government Spending Watch data, available at: governmentspendingwatch.org

93. See details of the drop in aid contributions to the health budget by $99 \%$ in endnote 164 .

94. For examples of poor women being more likely to use public healthcare facilities see Oxfam (2008) Malawi Essential Health Services Campaign, For All Campaign Country Case Study', http:// policy-practice. oxfam. org.uk/publications/malawi-essential-healthservices-campaign-country-case-study-112513; and L. Chakraborty, Y. Singh and J.F. Jacob (2013) 'Analyzing Public Expenditure Benefit Incidence in Health Care: Public Expenditure Benefit Incidence in Health Care:
Evidence from India', Levy Economics Institute, Working Papers Series No. 748, http://levyinstitute.org/ publications/analyzingpublic-expenditure-benefitincidence-in-health-care

95. African Arguments, 'Malawi faces toughest, most high-profile trail yet in massive Cashgate scandal', 8 February 2017. http:/ /africanarguments. org/2017/02/08/malawi-faces-toughest-most-highprofile-trial-yet-in-cashgate-scandal/

96. The Times Group, 'ACB helpless on Bingu Wa Mutharika wealth', Op. Cit.

97. For example, B. Chinsinga and G.Chigona (2010) The State of Intra-party Democracy in Malawi: Comparative Audit of Selected Party Constitutions. A Report Prepared for the Centre for Multiparty Democracy Malawi (CMD-M) http://www.eldis.org/vfile/upload/1/ document/1106/The\%20state\%20of\%20intra\%20 party\%20democracy\%20in\%20Malawi.pdf

98. World Economic Forum (2017). Op. cit.; T. O'Neil, N. Kanyongolo and J. Wales, with M. Walita Mkandawire (2016). Women and Power: representation and influence in Malawi's parliament. Overseas Development Institute available at: https://www.odi.org/sites/odi.org.uk/ files/odi-assets/publications-opinion-files/10289.pdf

99. K. Bridges and M. Woolcock (2017). How (Not) to Fix Problems That Matter - Assessing and Responding to Malawi's History of Institutional Reform, World Bank Group, Policy Research Working Paper 8289.

100. Ibid.

101. Afrobarometer, Malawi: http://afrobarometer.org/ countries/malawi-0

102. Southern African Development Community Secretariat (2009), SADC Framework for Achieving Gender Parity in Political and Decision Making Positions by 2015 .
103. For example, on the economic benefits of highe labour force participation, see: IMF (2013). Women, Work and the Economy; Macroeconomic Gains from Gender Equity. http://www.imf.org/external/pubs/ft/ sdn/2013/sdn1310.pdf

104. UNDP, Gender Inequality Index. Accessed January 2018 at: http://hdr.undp.org/en/composite/GII

105. WEF (2017) The Global Gender Gap Report. World Economic Forum. http://www3.weforum.org/docs/ WEF_GGGR_2017.pdf

106. UN Women, UNDP, UNEP and the World Bank Group (2015). Op. cit.

107. See NSO (2012). Op. cit. and NSO (2017). 0p. cit.

108. NSO and ICF (2011). Malawi Demographic and Health Survey 2010. Zomba, Malawi and Rockville, Maryland, USA, and NSO and ICF (2017).

109. NSO and ICF (2017). Op. cit.

110. Ibid.

111. UNICEF, UNICEF Data: Monitoring the Situation of Children and Women, https://data.unicef.org/ topic/child-protection/child-marriage/ and WHO (2013). Child marriages: 39000 every day, http://www. who.int/mediacentre/news/releases/2013/child marriage 20130307/en/

112. UNDP in Malawi (2016). Op. cit.

113. Ibid.

114. NSO and ICF (2017). Op. cit.

115. UN Women (2017). Malawi Parliament adopts amendment to end child marriage. 22 February 2017 available at: http://www.unwomen.org/en/news/ stories/2017/2/news-malawi-parliament-adoptsamendment-to-end-child-marriage

116. NSO and ICF (2017). Op. cit.

117. E. Seery (2014). Op. cit.

118. See World Economic Forum (2017). Op. cit. where Malawi scores poorly on political participation, compared to other areas.

119. OECD (no year). Donor Support to Southern Women's Rights Organisations: OECD findings. https://www. oecd.org/dac/gender-development/OECD-report-onwomens-rights-organisations.pdf

120. NSO and ICF (2017) 0p. cit.

121. UNDP (2016). African Human Development Report 2016: Accelerating Gender Equality and Women's Empowerment in Africa. https://www.afdb.org/ fileadmin/uploads/afdb/Documents/AEC/2016/AfHDR_
Summary_highres_EN.pdf

122. World Bank (2017al. Malawi Economic Monitor: Land for Inclusive Development, https:// openknowledge.worldbank.org/bitstream handle/10986/28888/121419-WP-P164538-MalawiEconomic-Monitor-6-Land-for-Inclusive-Development. pdf? sequence $=68$ is Allowed $=y$

123. NSO and ICF (2017). Op. cit.

124. See A. Valverde (2016). WE-Care Malawi Programme Report: Linking unpaid care work and mobile value-added services in Malawi. Oxfam. https://oxfamilibrary.openrepository.com/oxfam/ bitstream/10546/620125/1/er-we-care-malawi-ictsmobile-021116-en.pdf

125. UNHLP (2017). Leave No one Behind: Taking Action for Transformational Change on Women's Economic Empowerment. Report of the UN Secretary General's High-Level Panel on Women's Economic Empowerment. http://hlp-wee.unwomen.org/-/media/hlp\%20wee/ attachments/reports-toolkits/hlp-wee-report-201703-taking-action-en pdf?la=en

126. Malawi Government (2017) The Malawi Growth and Development Strategy (MGDS) III - Building a Productive, Competitive and Resilient Nation.

127. http://blogs.worldbank.org/eastasiapacific/ cambodia-poverty-reduction-shared-prosperity 


\section{Closing the divide in Malawi How to reduce inequality and increase prosperity for all}

128. World Bank, World Development Indicators.

129. MAIWD (2016). Malawi National Agriculture Policy. Ministry of Agriculture, Irrigation and Water Development. Lilongwe, Malawi.

130. NSO (2014). Malawi Labour Force Survey 2013. ILO and National Statistical Office, Zomba, Malawi.

131. NSO (2017). Op. cit.

132. Government of Malawi, 2016-2017 Budget Statement delivered in the National Assembly of the Republic of Malawi by the Minister of Finance, Economic Planning and Development.

133. The IHS4 (NSO 2017) reports a large proportion $61 \%$ - of the population in Malawi experienced high food insecurity during the week prior to their interview, compared to $32 \%$ reporting in the $1 \mathrm{H3}$ for 2010/2011.

134. According to the $2006 / 07$ agricultural census, which is the most recent available.

135. H. Moylan (2017) op. cit.

136. FAO (2011). Gender Inequalities in Rural Employment in Malawi: An Overview. Food and Agriculture Organization. http://www.fao.org/docrep/016/ap092e/ ap092e00.pdf

137. Women-headed households on average cultivate 0.8 hectares compared to an average 1.7 hectares for men (2009-2010 season). IHS4 (NSO 2017) states that in 2017, women headed households cultivated an average 1.2 hectares of land, though $57 \%$ of these farmed land below one hectare. The average for men remains 1.7 hectares. According to UNDP, in Malawi only household with more than 0.8-1.0 hectares can produce enough maize, raise a sufficient number of head of cattle and obtain credit for agricultural inputs. See: "The Dynamics of Income Inequality in a Dualistic Economy: Malawi over 1990-201" December 2017, Income Inequality Trends in sub-Saharan Africa: Divergence, determinants and consequences. Publisher: UNDP, Editors: Ayodele Odusola, Giovanni Andrea Cornia, Haroon Bhorat, Pedro Conceição.

138. Oxfam (2016a). Making Maize Markets Work. Oxfam Briefing Note, 12 September 2016.

139. See FAO (2013). Climate-Smart Agriculture? A review of current practice of agroforestry and conservation agriculture in Malawi and Zambia. ESA Working Paper No 13-07. http://www.fao.org/3/a-ar715e.pdf

140. See Stephen Carr, a British agronomist living in Malawi, commenting on the matter in response to the following blog by Max Lawson, Head of Development Finance and Public Services for Oxfam GB, December 2010: https://oxfamblogs.org/fp2p/how-fertilisersubsidies-have-transformed-malawi/

141. NSO (2010). National Census of Agriculture and Livestock (NACAL) 2006/07: Main Report. Zomba, Malaw http://www.nsomalawi.mw/images/stories/data_on line/agriculture/NACAL/Nacal\%20Report.pdf

142. World Bank (2017a). Op. cit.

143. Lawson, M. (2002) ‘Death at the doorsteps of the Summit'. Briefing Paper, Oxfam International https:// policy-practice.oxfam.org.uk/publications/death-onthe-doorstep-of-the-summit-114112

144. M. Kutengule, A. Nucifora and H. Zaman (2006) Agricultural Development and Marketing Corporation Reform' in A. Coudouel, A.A. Dani and S. Paternostro (eds.). Poverty and Social Impact Analysis of Reforms. The World Bank.

145. All Oxfam, CISANET and CADECOM (2016). Hunger Bites: the state of maize availability in AMDARC markets in Malawi. A study by Oxfam, Civil Society Agriculture Network (CISANET) and Catholic Development Commission of Malawi (CADECOM).

146. World Bank (2017b). Malawi Economic Monitor: Harnessing the Urban Economy. May 2017, Lilongwe, Malawi: The World Bank.

147. World Bank (2017a). Ibid.
148. S. Fabrizio, D. Furceri, R. Garcia-Verdu, B.G. Li, S.V. izarazo Ruiz, M. Mendes Tavares, F. Narita, A. PeraltaAlva (2017). Macro-Structural Policies and Income Inequality in Low Income Developing Countries. IMF Discussion Note SDN/17/01, January 2017. Washington DC: International Monetary Fund.

149. See for example, S.Kidd et al (2017) Exclusion by design: An assessment of the effectiveness of the proxy means test poverty targeting mechanism and M Lawson et al (2001) TIP 2000-2001 Targeted Inputs Programme

150. Malawi Integrated Household Panel Survey 2016, H. Moylan (2017) op. cit.

151. Chisinga, Blessing (2011) 'Agro- dealers, Subsidies and Rural Market Development in Malawi: A Political Economy Enquiry'. Working Paper 031, www.futureagricultures.org.

152. Dorward, Andrew and Chirwa, Ephraim and Matita, Mirriam and Mhango, Wezi and Mvula, Peter and Taylor, Edward J and Thorne, Karen (2013) Evaluation of the 2012/13 Farm Input Subsidy Programme, Malawi: Final Report. London: Centre for Development, Environment and Policy, SOAS, University of London. (Unpublished) Available at https://core.ac.uk/download/ pdf/19090642.pdf

153. Christopher Chibwana, Monica Fisher (2011) 'The impacts of agricultural input subsidies in Malawi'. Policy Note No. 5, Malawi Strategy Support Program. IFPR

154. Karamba, R.W., 2013. Input subsidies and their effect on cropland allocation, agricultural productivity, and child nutrition: evidence from Malawi, Faculty of College of Arts and Sciences. American University.

155. C. Chibwana and M. Fisher (2011). The impacts of agricultural input subsidies in Malawi. Policy Note No. 5 , International Food Policy Research Institute (IFPRI).

156. B. Chinsinga (2011). Op. cit.

157. Ibid

158. UN Women, UNDP, UNEP and the World Bank Group (2015). Op. cit.

159. Finmark Trust (2012). FinScope MSME Survey Malawi 2012. https://info.undp.org/docs/pdc/Documents/ MWI/Malawi\%202012\%20MSME\%20Main\%20Report\%20 -\%20Final.pdf

60. This paragraph is based on recommendation outlined in Oxfam (2016a). Op. cit.

161. C. Mariotti and A. Shepherd (2015). Tackling Extreme Poverty Through Private Sector Development Policy Guide. Chronic Poverty Advisory Centre, London: Overseas Development Institute.

162. Defined by the 2013 Labour Force Survey INSO, 2014) as the share of the employed persons in the age group 15-64 years who, during the reference period of one week, were working as contributing family workers one week, were working as contributing family workers NSO (2014) Malawi Labour Force Survey 2013. ILO and National Statistical Office, Zomba, Malawi.

163. NSO (2014). Op. cit.

164. Oxfam and ETP (2013). Understanding Wage Issues in the Tea Industry4F. Oxfam and Ethical Tea Partnership. https://oxfamilibrary.openrepository.com/oxfam/ https:// oxfamilibrary.openrepository.com/oxfam/ industry-wage-020513-en.pdf

165. UNDP (2016). Human Development for Everyone. Briefing note for countries on the 2016 Human Development Report - Malawi. United Nations Development Program.

166. "Malawi govt increases minimum wage for all workers from K787.70 to K962.00 per day", 12 July 2017, workers from K787.70 to K962.00 per day", 12 July 2017, minimum-wage-workers-k787-70-k962-00-per-day/ minimum-wage-workers-
All $\$$ calculations xe.com

167. All S calculations xe.com

68. Pricewaterhouse Coopers South Africa (2010). Remuneration trends report in Southern Africa. Pricewaterhouse Coopers. South Africa. www.pwo. $\mathrm{com} / \mathrm{za}$
69. FAO (2011). Op. cit

70.NSO and ICF (2017). Op. cit.

171. IMF (2015a). Fiscal Policy and Long-Term Growth. https://www.imf.org/external/np/pp/ eng/2015/042015.pdf

172. E. Seery (2014) op. cit.

173. IMF (2017b). Country Report No. 17/183. Malawi Ninth Review Under the Extended Credit Facility Arrangement and Request for Waivers for Nonobservance of Performance Criteria - Press Release Staff Report; and Statement by the Executive Director for Malawi. https://www.imf.org/en/Publications/CR/ Issues/2017/07/05/Malawi-Ninth-Review-Under-the Extended-Credit-Facility-Arrangement-and-Requestfor-Waivers-45036

174. 'Malawi Case Study'. Jubilee Debt Campaign http://jubileedebt.org.uk/countries/malawi; and Malawi's planned health spending in 2015-16 was US\$168,425,663 (current US dollar), based on Government Spending Watch data, available at: governmentspendingwatch org.

175. World Bank (2017b). Op. cit.

176. M. Lawson and M. Martin (2017). The Commitment to Reducing Inequality Index: A new global ranking of governments based on what they are doing to tackle the gap between rich and poor. Development Finance International and Oxfam. July 2017. https://policypractice.oxfam.org.uk/publications/the-commitmentp-reducing-inequality-index-a-new-globat-ranking f-governments-620316

177. Ibid.

178. IMF (2014). Fiscal Policy and Income Inequality. IMF Policy Paper, Washington, D.C.: IMF, Figure 8. https:/// www.imf.org/external/np/pp/eng/2014/012314.pd

179. http://www.mra.mw/tax-update/vatamendments-gazetted

180. M. Lawson and M. Martin (2017). Op. cit.

181. IMF (2017b). Op. cit.

182. "Malawi. Corporate: Taxes on corporate income". http://taxsummaries.pwc.com/ID/Malawi-CorporateTaxes-on-corporate-income

183. Data and analysis in this paragraph are based on Oxfam's Commitment to Reducing Inequality (CRI database (op. cit.) and on M. Martin (2017). 'Domestic Resource Mobilisation in Southern Africa: Implications for Anti-inequality Campaigns'. Presentation for Oxfam Regional Workshop, Lilongwe, 24 January 2017.

184. All data in this paragraph come from Oxfam's Commitment to Reducing Inequality Index Database, available upon request.

185. ActionAid (2016). The UK's treaty with Malawi is outdated and unfair: it's time Malawi got a better deal. 186. All ibid.

187. Ibid.

188.According to ActionAid, a revised version of the treaty was negotiated in 2016, but the signing and ratifying process has stalled for political reasons.

189. A. Cobham and P. Jansky (2017). Global distribution of revenue loss from tax avoidance: Re-estimation and country results. Working Paper 2017-55. UNU-WIDER. https://www.wider.unu.edu/sites/default/files/ wp2017-55.pdf

190. Oxfam (2017) Position Paper Gender Justice and the Extractive Industries.

191. IMF (2017b). Op. cit.

192. World Bank (2015). Malawi Economic Monitor. Managing Fiscal Pressure. March, 2015

93. Oxfam (2016b). Future mining revenues for Malawi. Case study of Mkango's Songwe Hill Project.

194. Ibid. 


\section{Closing the divide in Malawi How to reduce inequality and \\ increase prosperity for all}

195. However, according to Mkango's website, in November 2016 the company entered into agreement with the company Talaxis to Fund Development of the Songwe Hill Rare Earths Project in Malawi and Commercialisation of New Magnet Technologies. http:// www. mkango.ca/s/news.asp?ReportID =807802

196. Oxfam (2016b). Op. cit.

197. Global Partnership for Effective Development Cooperation (2016) Malawi Monitoring Profile - October 2016. http://effectivecooperation.org/wp-content/ uploads/2016/10/Malawi_10_10.pdf

198. Ibid

199. See Table 2.a for details of decline in budget support grants. IMF (2016) Malawi, IMF Country Report No. 16/182.

200. Global Partnership for Effective Development Cooperation (2016), Op. cit.

201. Ministry of Health slides, Initiatives Improving Access and Coverage in the Context of UHC, HSSP and Reforms, shared with Oxfam in Malawi at UHC workshop 14-16 April 2016.

202. In 2013/14, planned donor-funded spending on health was $\$ 89,199,977$, and 2014/15 revised donor-funded spending on health was $\$ 1,113,708$, representing a fall of $99 \%$. All current US dollars. Government Spending Watch data, available at governmentspendingwatch.org

203. The maternal mortality ratio per 100,000 live births (modelled estimate) increased from 618 in 2011 to 638 in 2014, increasing in each of the intervening years. World Bank, World Development Indicators.

204. Global Partnership for Effective Development Cooperation (2016). Op. cit.

205. See 'Malawi Case Study', Jubilee Debt Campaign http://jubileedebt.org.uk/countries/malawi

206. E. Seery (2014), op. cit.

207. Ibid.

208. Government of Malawi (2017). Health Secto Strategic Plan II, 2017-2022, Towards Universal Health Coverage.

209. WHO (2017), 'Universal Health Coverage Fact Sheet'. http://www.who.int/mediacentre/factsheets/fs395/ en/

210. Ibid

211. See F. Rhodes (2017). Women and the 1 percent: how extreme economic inequality and gender inequality must be tackled. Oxfam. https://policy-practice.oxfam. org.uk/publications/women-and-the-l-how-extremeeconomic-inequality-and-gender-inequality-mustbe-t-604855; E. Burgisser and S. Nissan (2016) The IMF and Gender - A Critical Analysis, Bretton Woods Project. http://www.brettonwoodsproject.org/wp-content/ uploads/2016/06/final-gender-briefing-1-fo ettor-onlineersion-7.pd

212. E. Seery (2014) 0p. cit.

213. J. Hamer (2016). The Right Choices: Achieving Universal Health Coverage in Malawi, Oxfam

International. https://policy-practice.oxfam.org.uk/ publications/the-right-choices-achieving-universalhealth-coverage-in-malawi-611820

214. Government of Malawi (2017). Op. cit., p.16.

215. In government health facilities. Ibid., p.15.

216. Ibid., Figure 10, p.63.

217. J. Hamer (2016). Op. cit.
218. See, for example, P. Kumbani (2016). 'MoH Hails Bypass Fee System', The Nation, 9 February 2016, http:// mwnation.com/moh-hails-by-pass-fee-system/ and $\mathrm{E}$. Nantchengwa (2016). 'Congestion Hit Malawi Hospitals'. The Daily Star, 23 March 2016, https:/ / www.malawistar. com/2016/03/23/congestion-hit-malawi-hospitals/ and A. Makina (2015). 'Malawi Hospitals Start Charging K25,000 Per Referral'. Malawi24, 5 December 2015.

219. Originally featured in J. Hamer (2016). Op. cit.

220. L. Gilson (1997). 'The Lessons of User Fee

Experience in Africa'. Health Policy and Planning, 12

273-285. https://doi.org/10.1093/oxfordjournals. heapol.a018882

221. J. Hamer (2016). Op. cit., p.8.

222. Ibid., p.6.

223. Ibid.

224. W. Mwale (2016). 'User fee in public hospitals starts July'. The Times Group, 10 May 2016. http://www.times. mw/user-fee-in-public-hospitals-starts-july/

225. Details of proposed CHAM SLA reform were found in Ministry of Health slides, Initiatives Improving Access and Coverage in the Context of UHC, HSSP and Reforms', shared with Oxfam in Malawi at UHC workshop, 14-16 April 2016.

226. Government of Malawi (2017). Op. cit., p.2; J. Hamer (2016). Op. cit.

227. Ministry of Health slides, shared April 2016, op. cit. 228. Quoted in C. Averill (2013). Universal Health Coverage - Why health insurance schemes are leaving the poor behind. Op. cit.

229. Ibid.

230. Citi FM Online, 'Reviewing NHIS: Committee pushes for guaranteed primary healthcare for all', 24 June 2016. http://citifmonline.com/2016/06/24/reviewing-nhiscttee-pushes-for-guaranteed-primary-healthcarecttee-push
for-all/

231. C. Averill (2013). Op. cit.

232. E. Amporfu (2013) 'Equity of the premium of the Ghanaian national health insurance scheme and the implications for achieving universal coverage', International Journal for Equity in Health, 12:4.

233. C. Averill (2013). Op. cit.

234. African Summit on HIV/AIDS, Tuberculosis and other related infectious diseases (2001) Abuja Declaration on HIV/AIDS, Tuberculosis and other related infectious diseases, Abuja, Nigeria, 24-27 April 2001.

235. C. Averill (2013). 0p. cit.

236. Based on calculations for the financing gap for HSSP II, which includes donor contributions, as outlined above.

237. World Bank (2017c) Fiscal Space for Health in Malawi and Revenue Potential of 'Innovative Financing. World Bank, Washington, DC. https://openknowledge. worldbank.org/handle/10986/28404

238. Aid conditions should for example avoid feeding perverse incentives for corrupt behaviour, and be informed by a detailed analysis of risks around aid and corruption, as discussed earlier in this paper.

239. As per the Paris Declaration on Aid Effectiveness and the Accra Agenda for Action.

240. World Bank, World Development Indicators.

241. M. San Sebastian and H. Lemma (2010). Efficiency of the Health Extension Programme in Tigray, Ethiopia: A Data Envelopment Analysis. BMC International Health and Human Rights.

242. World Bank, World Development Indicators.

243. World Bank (2017c), op. cit.

244. Ibid.
245. N. Hall and M. Mambo (2015). Financing Education in Malawi, Opportunities for Action - Country case study for the Oslo Summit on Education for Development, p. 5 .

246. E. Seery (2014). Op. cit.

247.S. Al-Samarrai and H. Zaman (2007). Op. cit., p.5.

248.At primary level, net school attendance ratios were at 94.7 for urban areas and 93.8 for rural areas in $2015 / 16$. A gap persists at secondary level, however. NSO and ICF (2017). Op. cit.

249. NSO and ICF (2017). Op. cit.

250. According to a 2013/14 UNESCO factsheet lat the time of writing no access to full Integrated Household Survey 4 dataset): UNESCO (2014). Teaching and learning: Achieving quality for all. Malawi: Fact Sheet. http:// Achieving quality for all. Malawi: Fact Sheet.http:// pdf/Malawi Factsheet.pdf.

251. N. Hall and M. Mambo (2015). Op. cit., p.5.

252. Ibid. and S. Al-Samarrai and H. Zaman (2007). Op. cit., p. 364 .

253. N. Hall and M. Mambo (2015). Op. cit., p.2.

254. H. Moylan (2017), op. cit.

255. T. Smeeding (2005). 'Public Policy, Economic nequality, and Poverty: The United States in Comparative Perspective' in Social Science Quarterly. Vol. 86 (suppl): 955-83.

256. N. Hall and M. Mambo (2015). Op. cit.

257. Education 2030 (UNESCO et al) (2015) Incheon Declaration and Framework for Action for the implementation of Sustainable Development Goal 4. http://unesdoc.unesco.org/ images/0024/002456/245656e.pd

258. See for example, the MWK 500m education budget cut in 2016 midway through the fiscal year. Nyasa Times, 'Malawi govt MPs celebrate K500mil cut on education budget', 9 March 2016. http:// www.nyasatimes. $\mathrm{com} /$ malawi-govt-mps-celebrate-k500mil-cut-oneducation-budget/

259. ActionAid (2017). Low quality of public schools drives parents towards private education in Malawi; and UNESCO (2014) EFA Global Monitoring Report 2013/14, Teaching and Learning: Achieving quality for all, p.268. 8 260. N. Hall and M. Mambo (2015). Op. cit.

261. Ibid.

262. NSO and ICF (2017). Op. cit.

263. M. Mambo and J. Salmi (2016). Improving Higher Education in Malawi for Competitiveness in the Global Economy: A World Bank Study. https://issuu.com/world. bank.publications/docs/9781464807985

264. N. Hall and M. Mambo (2015). Op. cit.

265. Ibid.

266. Malawi Government (2017) op. cit.

267. ILO (2016). Social Protection in Malawi. Assessment Based National Dialogue Brief. International Labour Organization and Irish Aid. http://www.ilo.org/ addisababa/information-resources/publications/ WCMS_493330/lang--en/index.htm

268. Ibid.

269. Figures from database in M. Lawson and M. Martin (2017). Op. cit

270. R. Record, P. Kandoole, G. Hoglund and G.M. Asa (2016). Malawi economic monitor: absorbing shocks, building resilience, May 2016. Washington, D.C.: World Bank Group http://documents. worldbank.org/curated/ en/791871467991930988/Malawi-economic-monitorabsorbing-shocks-building-resilience

271. IMF (2015b). Malawi. Selected Issues. IMF Country Report No. 15/346. December 2015 


\section{Closing the divide in Malawi \\ How to reduce inequality and \\ increase prosperity for all}

\section{Acknowledgements}

This report was written by Chiara Mariotti, Jessica Hamer and Clare Coffey.

The report was edited by Claire Godfrey and Jane Garton.

Oxfam is grateful to the many other Oxfam colleagues and external partners who gave written inputs, valuable comments and support to the initial thinking and final drafts of this report. Special mention should be made to:

- John Makina, Lingalireni Mihowa, Lusungu Dzinkambani, Mathias Kafunda, Anthony Malunga.

- Rowan Harvey, Max Lawson, Oli Pearce, Anna Marriott, Deborah Hardoon, Hilary Jeune, Susana Ruiz Rodriguez.

- External Reviewers- Donald Makoka - Research Fellow (Lilongwe University of Agriculture $\delta$ Natural Resources); Grain Malunga - Fellow (Institute of Materials, Minerals \& Mining); Steve Sharra - Director of Research \& Publications (Catholic University of Malawi); Priscilla Kandoole-Country Economist (World Bank Malawi Office); Patrick Kamwendo - Economic Specialist (UNDP Malawi); Winford Masanjala - Associate Professor (University of Malawi Chancellor College).

In addition, Oxfam is grateful for the contributions emanating from interviews in November 2016 which initially informed the scope of the report, including with: Dr. Mary Shawa, Ministry of Gender, Children, Disability And Social Welfare, Principal secretary; Mabvuto Bamusi, Office of the President and Cabinet, Advisor; Dr. Douglas Lungu, Medical Practitioner ; Beyani Munthali, Employment Consultation Association of Malawi, Executive Director; Emily Mkamanga, Social Commentator on Political $\&$ Social Issues; George Harawa, Coordinator for Malawi Extractive Industry Transparency Initiative (MWEITI); and representatives of UNDP, DFID and the British High Commission in Malawi, Council for Higher Education, and Ministry of Finance.

Special thanks to Sarah Hall, Lusungu Dzinkambani, Mathias Kafunda for their support throughout the report development and finalization process, as well as coordination and production.

Design of the report was by Nigel Willmott.

For further information on the issues raised in this paper please email advocacy[oxfaminternational.org 



\section{Oxfam International April 2018}

This publication is copyright but the text may be used free of charge for the purposes of advocacy, campaigning, education, and research, provided that the source is acknowledged in full. The copyright holder requests that all such use be registered with them for impact assessment purposes. For copying in any other circumstances, or for re-use in other publications, or for translation or adaptation, permission must be secured and a fee may be charged. E-mail policyandpractice@oxfam.org.uk

The information in this publication is correct at the time of going to press.

Published by Oxfam GB for Oxfam International under ISBN 978-1-78748-179-4 in April 2018.

DOI: $10.21201 / 2017.1794$

For more information, or to comment on this report, email: infomalawi@oxfam.org.uk

\section{Oxfam}

Oxfam is an international confederation of 20 organizations networked together in more than 90 countries, as part of a global movement for change, to build a future free from the injustice of poverty.

www.oxfam.org

\section{Oxfam in Malawi}

Green Heritage Building

City Centre Area 13

Private Bag B331, Lilongwe

Tel 002651770 489/525/563

Email: infomalawidoxfam.org.uk 